\title{
Carbocyclization Reaction of $\omega$-lodo- and 1,w-Diiodo-1-alkynes without the Loss of lodine Atoms trough a Carbenoid-Chain Process
}

Toshiro Harada, ${ }^{*}$ Keiko Muramatsu, Kenta Mizunashi, Chie Kitano, Daisuke Imaoka, Takayuki Fujiwara, and Hiroshi Kataoka

Department of Chemistry and Materials Technology, Kyoto Institute of Technology, Matsugasaki, Sakyo-ku, Kyoto 606-8585, Japan

1. General

S-2

2. Preparation of lodoalkynes 13

S-2

3. Preparation of Diiodoalkynes 14

4. Cycloisomerization of lodoalkynes 13

5. Deuterium Scrambling Experiment

6. Cycloisomerization of Diiodoalkynes 14

7. Atom-Transfer Type Cyclization of lodoalkynes 13

8. ${ }^{1} \mathrm{H}$ NMR Spectra of $15 e, f, \mathbf{g}, \mathbf{k}, 16 e, \mathbf{n}, \mathbf{p}$, and $19 \mathbf{g}, \mathbf{k}, \mathbf{I}$ 


\section{General.}

Dichloromethane and DMF were dried and distilled over $\mathrm{CaH}_{2}$. THF was dried and distilled over sodium benzophenone ketyl. Acetone was dried successively with drierite, $\mathrm{CaH}_{2}$, and molecular sieves 3A. Sodium iodide was dried in vacuo at $100{ }^{\circ} \mathrm{C}$ for $1 \mathrm{~h}$. Unless otherwise noted, all chemicals and reagents were obtained commercially and used without purification.

\section{Preparation of Iodoalkynes $13 .^{1}$}

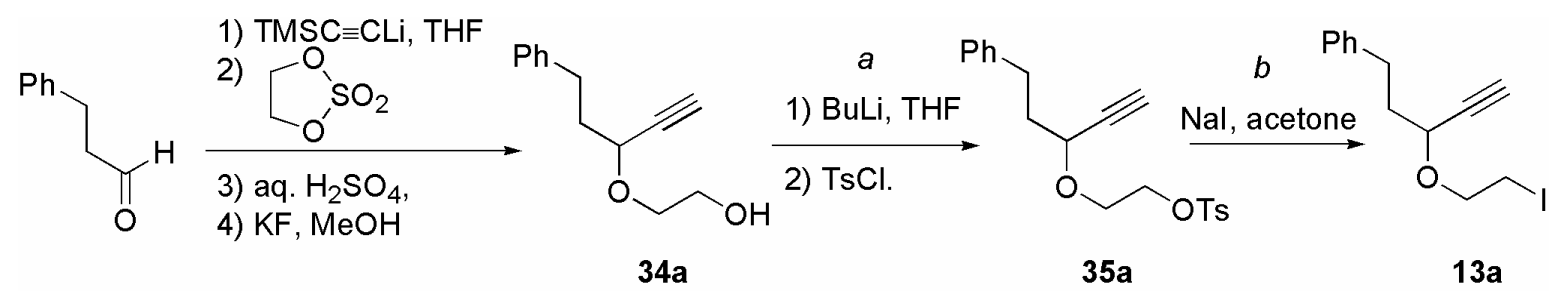

2-(1-Phenethylprop-2-ynyloxy)ethanol (34a). To a solution of ethynyltrimethylsilane (2.16 g, 22.0 $\mathrm{mmol})$ in THF $(28 \mathrm{~mL})$ at $0{ }^{\circ} \mathrm{C}$ under argon atmosphere was added BuLi $(1.6 \mathrm{M}$ in hexane) $(13.8 \mathrm{~mL}$, $22.0 \mathrm{mmol})$. The reaction mixture was stirred for $0.5 \mathrm{~h}$ at this temperature. To the resulting solution of trimethylsilylethynyllithium at $-78{ }^{\circ} \mathrm{C}$ was added 3-phenylpropanal (2.68 g, $\left.20.0 \mathrm{mmol}\right)$ during 10 min. The reaction mixture was allowed to warm to $-30{ }^{\circ} \mathrm{C}$ during $2 \mathrm{~h}$. A THF $(38 \mathrm{~mL})$ solution of 1,3,2-dioxathilane 2,2-dioxide $(2.74 \mathrm{~g}, 22.0 \mathrm{mmol})$ was added to the resulting solution of the alkoxide during $15 \mathrm{~min}$ at $-78{ }^{\circ} \mathrm{C}$. The reaction mixture was allowed to warm to room temperature during $2 \mathrm{~h}$, stirred at $50{ }^{\circ} \mathrm{C}$ for $20 \mathrm{~h}$, and then concentrated in vacuo. The residue was dissolved in ether $(110 \mathrm{~mL})$ and stirred vigorously with $20 \%$ aqueous $\mathrm{H}_{2} \mathrm{SO}_{4}(110 \mathrm{~mL})$ at room temperature for $20 \mathrm{~h}$. The mixture was diluted with ether $(110 \mathrm{~mL})$ and water $(110 \mathrm{~mL})$. The organic layer was separated and the aqueous layer was extracted with ether $(60 \mathrm{~mL})$. The combined organic layers were washed with brine, dried $\left(\mathrm{MgSO}_{4}\right)$, and concentrated in vacuo. The resulting crude trimethylsilyl alcohol was vigorously stirred with $3 \mathrm{~N} \mathrm{NaOH}$ in methanol $(16 \mathrm{~mL})$. The mixture was poured into water $(30 \mathrm{~mL})$ and extracted with ether $(60 \mathrm{~mL} \times 3)$. The combined organic layers was washed with brine, dried $\left(\mathrm{MgSO}_{4}\right)$, and concentrated in vacuo. Kugelrohr distillation $\left(110-150{ }^{\circ} \mathrm{C} / 0.05 \mathrm{mmHg}\right)$ gave $3.42 \mathrm{~g}$ ( $83 \%$ yield) of 34a. ${ }^{1} \mathrm{H}$ NMR $\left(500 \mathrm{MHz}, \mathrm{CDCl}_{3}\right) \delta 1.83(1 \mathrm{H}, \mathrm{br}), 2.01-2.15(2 \mathrm{H}, \mathrm{m}), 2.49(1 \mathrm{H}, \mathrm{d}, \mathrm{J}=1.9 \mathrm{~Hz}), 2.81(2 \mathrm{H}$, $\mathrm{t}, J=7.8 \mathrm{~Hz}), 3.51(1 \mathrm{H}, \mathrm{m}), 3.73-3.82(2 \mathrm{H}, \mathrm{m}), \quad 3.85(1 \mathrm{H}, \mathrm{m}), 4.06(1 \mathrm{H}, \mathrm{dt}, J=1.9$ and $6.6 \mathrm{~Hz}), 7.17-$ 7.32 (5H, m); IR (liquid film) 3420 (br), 3290, 2120, 1110, 1055, 750, $700 \mathrm{~cm}^{-1}$; MS (CI), $\mathrm{m} / z$ (relative intensity) $205\left(\mathrm{MH}^{+}, 23\right), 143$ (100); HRMS (EI) calcd for $\mathrm{C}_{13} \mathrm{H}_{16} \mathrm{O}_{2}$ 204.1150, found; 204.1156.

1 Iodoalkyne 13i was prepared according to the literature procedure; Yanada, R.; Koh, Y.; Nishimori, N.; Matsumura, A.; Obika, S.; Mitsuya, H.; Fujii, N.; Takemoto, Y. J. Org. Chem. 2004, 69, 2417. 
2-(1-Phenethylprop-2-ynyloxy)ethyl p-Toluenesulfonate (35a); Typical Procedure for Step a. To a solution of 34a (3.53 g, $17.3 \mathrm{mmol})$ in THF $(40 \mathrm{~mL})$ at $-78{ }^{\circ} \mathrm{C}$ was added BuLi (1.6 $\mathrm{M}$ in hexane) (11.5 mL, $18.4 \mathrm{mmol})$. After being stirred for $1 \mathrm{~h}$, a THF $(16 \mathrm{~mL})$ solution of $p$ toluenesulfonyl chloride $(3.38 \mathrm{~g}, 18.4 \mathrm{mmol})$ was added to the mixture at $-78{ }^{\circ} \mathrm{C}$. The reaction mixture was allowed to warm to $0{ }^{\circ} \mathrm{C}$ over $3 \mathrm{~h}$ and poured into water. The mixture was extracted with ether ( 80 $\mathrm{mL} \times 2)$. The organic layers were washed with $10 \%$ aqueous $\mathrm{NaHCO}_{3}$, dried $\left(\mathrm{MgSO}_{4}\right)$, and concentrated in vacuo. Purification of the residue by flash chromatography $\left(\mathrm{SiO}_{2}, 6-20 \%\right.$ ethyl acetate in hexane) gave $5.51 \mathrm{~g}$ (89\% yield) of 35a: ${ }^{1} \mathrm{H}$ NMR $\left(500 \mathrm{MHz}, \mathrm{CDCl}_{3}\right) \delta 1.88-2.02(2 \mathrm{H}, \mathrm{m}), 2.41(3 \mathrm{H}$, s), $2.44(1 \mathrm{H}, \mathrm{d}, J=2.0 \mathrm{~Hz}), 2.65-2.75(2 \mathrm{H}, \mathrm{m}), 3.57(1 \mathrm{H}, \mathrm{ddd}, J=4.1,6.2$, and $11.2 \mathrm{~Hz}), 3.90(1 \mathrm{H}$, ddd, $J=4.0,4.8$, and $11.2 \mathrm{~Hz}), 3.96(1 \mathrm{H}, \mathrm{dt}, J=2.0$ and $6.6 \mathrm{~Hz}), 4.16-4.27(2 \mathrm{H}, \mathrm{m}), 7.14-7.22(3 \mathrm{H}, \mathrm{m})$, $7.25-7.32(2 \mathrm{H}, \mathrm{m}), 7.32(2 \mathrm{H}, \mathrm{d}, J=8.2 \mathrm{~Hz}), 7.80(2 \mathrm{H}, \mathrm{d}, J=8.2 \mathrm{~Hz}) ;{ }^{13} \mathrm{C}$ NMR $\left(125.8 \mathrm{MHz}, \mathrm{CDCl}_{3}\right) \delta$ $21.4,30.9,36.8,65.9,68.7,69.0,74.6,81.8,125.9,127.8,128.28,128.33,129.7,132.9,140.9,144.6$.

[3-(2-Iodoethoxy)pent-4-ynyl]benzene (13a); Typical Procedure for Step b. Sodium iodide was dried in vacuo at $100{ }^{\circ} \mathrm{C}$ for $1 \mathrm{~h}$. To a solution of sodium iodide $(1.02 \mathrm{~g}, 6.80 \mathrm{mmol})$ in acetone $(4.5$ $\mathrm{mL})$ was added a solution of $\mathbf{3 5 a}(1.63 \mathrm{~g}, 4.55 \mathrm{mmol})$ in acetone $(6.8 \mathrm{~mL})$ at room temperature. The mixture was heated for $5 \mathrm{~h}$ under reflux. The reaction mixture was concentrated in vacuo. The mixture was poured into water and extracted three times with ether. The combined organic layers were dried over $\mathrm{MgSO}_{4}$ and concentrated in vacuo. The residue was purified by Kugelrohr distillation (130 ${ }^{\circ} \mathrm{C} / 0.2 \mathrm{mmHg}$ ) to give $1.16 \mathrm{~g}$ (81\% yield) of 13a: ${ }^{1} \mathrm{H}$ NMR (500 MHz, $\left.\mathrm{CDCl}_{3}\right) \delta 2.98-2.16(2 \mathrm{H}, \mathrm{m}), 2.49$ $(1 \mathrm{H}, \mathrm{d}, J=2.0 \mathrm{~Hz}), 2.81(2 \mathrm{H}, \mathrm{t}, J=7.4 \mathrm{~Hz}), 3.23-3.32(2 \mathrm{H}, \mathrm{m}), 3.67(1 \mathrm{H}, \mathrm{td}, J=7.0$ and $10.5 \mathrm{~Hz}), 4.00$ $(1 \mathrm{H}, \mathrm{ddd}, J=6.1,7.1$, and $10.5 \mathrm{~Hz}), 4.06(1 \mathrm{H}, \mathrm{m}), 7.16-7.34(5 \mathrm{H}, \mathrm{m}) ;{ }^{13} \mathrm{C} \mathrm{NMR}\left(125.8 \mathrm{MHz}, \mathrm{CDCl}_{3}\right) \delta$ 2.7, 31.2, 37.1, 68.4, 69.3, 74.3, 82.3, 126.0, 128.4, 128.5, 141.1; MS (EI), $m / z$ (relative intensity) 314 $\left(\mathrm{M}^{+}, 0.5\right), 159$, (63), 142 (100); HRMS (EI) calcd for $\mathrm{C}_{13} \mathrm{H}_{15} \mathrm{OI}, 314.0168$, found; 314.0186 .

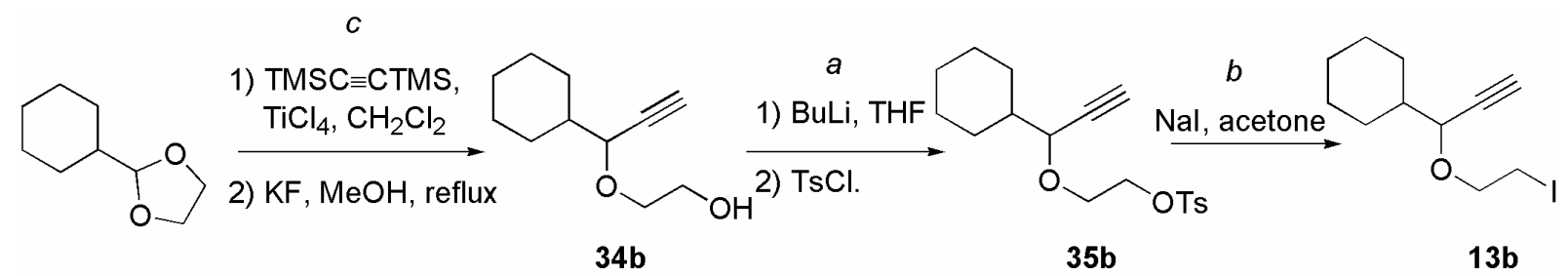

2-(1-Cyclohexylprop-2-ynyloxy)ethanol (34b); Typical Procedure for Step c. To a solution of 2cyclohexyl-1,3-dioxolane (2.26 g, $14.4 \mathrm{mmol})$ and bis(trimethylsilyl)acetylene $(9.20 \mathrm{~mL}, 36.5 \mathrm{mmol})$ in $\mathrm{CH}_{2} \mathrm{Cl}_{2}(300 \mathrm{~mL})$ at $-85^{\circ} \mathrm{C}$ was added $\mathrm{TiCl}_{4}(2.20 \mathrm{~mL}, 20.0 \mathrm{mmol})$. The reaction mixture was stirred for $1 \mathrm{~h}$ at this temperature and was quenched by the addition of methanol $(c a .10 \mathrm{~mL})$. The mixture was poured into $1 \mathrm{~N} \mathrm{HCl}$ and extracted three times with ether. The combined organic layers were washed twice with $1 \mathrm{~N} \mathrm{HCl}$ and concentrated in vacuo. The residue was treated with $\mathrm{KF}$ (3.39 g) in methanol $(56 \mathrm{~mL})$ under reflux for $1.5 \mathrm{~h}$. The mixture was poured into brine and extracted three times with ether. 
The organic layers were dried $\left(\mathrm{MgSO}_{4}\right)$ and concentrated in vacuo. Purification of the residue by flash chromatography ( $\mathrm{SiO}_{2}, 5-20 \%$ ethyl acetate in hexane) gave $2.38 \mathrm{~g}$ (91\% yield) of 34b: ${ }^{1} \mathrm{H}$ NMR (300 $\left.\mathrm{MHz}, \mathrm{CDCl}_{3}\right) \delta 1.18-1.33(5 \mathrm{H}, \mathrm{m}), 1.57-2.00(7 \mathrm{H}, \mathrm{m}), 2.44(1 \mathrm{H}, \mathrm{d}, J=2.1 \mathrm{~Hz}), 3.46-3.53(1 \mathrm{H}, \mathrm{m})$, 3.73-3.77 (2H, m), 3.81-3.88 (2H, m).

2-(1-Cyclohexylprop-2-ynyloxy)ethyl $p$-Toluenesulfonate (35b). The compound was prepared from 34b according to the procedure similar to that described above (step $a$ ). The crude product was purified by flash chromatography $\left(\mathrm{SiO}_{2}, 10 \%\right.$ ethyl acetate in hexane) to give $\mathbf{3 5 b}$ ( $88 \%$ yield): ${ }^{1} \mathrm{H}$ NMR $\left(500 \mathrm{MHz}, \mathrm{CDCl}_{3}\right) \delta 0.98-1.33(5 \mathrm{H}, \mathrm{m}), 1.54(1 \mathrm{H}, \mathrm{m}), 1.67-1.73(5 \mathrm{H}, \mathrm{m}), 2.42(1 \mathrm{H}, \mathrm{d}, J=2.1 \mathrm{~Hz}), 2.47$ $(3 \mathrm{H}, \mathrm{s}), 3.60(1 \mathrm{H}, \mathrm{ddd}, J=4.0,6.4$, and $10.7 \mathrm{~Hz}), 3.78(1 \mathrm{H}, \mathrm{dd}, J=1.9$ and $6.2 \mathrm{~Hz}), 3.91(1 \mathrm{H}, \mathrm{ddd}, J=$ 3.7, 5.2, and $11.4 \mathrm{~Hz}), 4.16-4.23(2 \mathrm{H}, \mathrm{m}), 7.36(2 \mathrm{H}, \mathrm{d}, J=8.2 \mathrm{~Hz}), 7.82(2 \mathrm{H}, \mathrm{d}, J=8.2 \mathrm{~Hz}) ;{ }^{13} \mathrm{C} \mathrm{NMR}$ $\left(125.8 \mathrm{MHz}, \mathrm{CDCl}_{3}\right) \delta 21.6,25.77,25.81,26.3,28.1,28.6,42.3,66.2,69.1,74.7,74.9,81.2,128.0$, $129.7,133.0,144.7$.

[1-(2-Iodoethoxy)prop-2-ynyl]cyclohexane (13b). The compound was prepared from 35b according to the procedure similar to that described above (step $b$ ). The crude product was purified by flash chromatography $\left(\mathrm{SiO}_{2}, 3 \%\right.$ ethyl acetate in hexane) to give 13b (91\% yield): ${ }^{1} \mathrm{H}$ NMR (500 MHz, $\left.\mathrm{CDCl}_{3}\right) \delta 1.06-1.34(5 \mathrm{H}, \mathrm{m}), 1.60-1.95(6 \mathrm{H}, \mathrm{m}), 2.47(1 \mathrm{H}, \mathrm{d}, J=2.0 \mathrm{~Hz}), 3.25-3.34(2 \mathrm{H}, \mathrm{m}), 3.68(1 \mathrm{H}$, td, $J=7.0$ and $10.6 \mathrm{~Hz}), 3.88(1 \mathrm{H}, \mathrm{dd}, J=2.0$ and $6.4 \mathrm{~Hz}), 4.01(1 \mathrm{H}, \mathrm{td}, J=6.9$ and $10.8 \mathrm{~Hz}) ;{ }^{13} \mathrm{C} \mathrm{NMR}$ $\left(125.8 \mathrm{MHz}, \mathrm{CDCl}_{3}\right) \delta 2.9,25.82,25.83,26.3,28.4,28.8,42.5,69.6,74.4,74.7,81.6$.

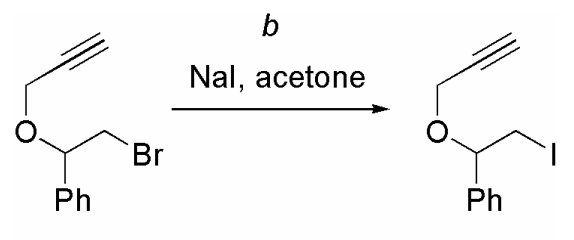

$13 c$

1-Iodo-3-oxa-2-phenyl-5-hexyne (13c). The compound was prepared from the corresponding bromide $^{2}$ according to the procedure similar to that described above (step $b$ ). The crude product was purified by Kugelrohr distillation $\left(130-135{ }^{\circ} \mathrm{C} / 0.05 \mathrm{mmHg}\right.$ ) to give $13 \mathrm{c}$ ( $91 \%$ yield): ${ }^{1} \mathrm{H}$ NMR (500 MHz, $\left.\mathrm{CDCl}_{3}\right) \delta 2.45(1 \mathrm{H}, \mathrm{t}, J=2.4 \mathrm{~Hz}), 3.36(1 \mathrm{H}, \mathrm{dd}, J=5.0$ and $10.5 \mathrm{~Hz}), 3.41(1 \mathrm{H}, \mathrm{dd}, J=8.0$ and $10.5 \mathrm{~Hz})$, $3.95(1 \mathrm{H}, \mathrm{dd}, J=2.4$ and $15.8 \mathrm{~Hz}), 4.21(1 \mathrm{H}, \mathrm{dd}, J=2.4$ and $15.8 \mathrm{~Hz}), 4.70(1 \mathrm{H}, \mathrm{dd}, 5.0$ and $7.9 \mathrm{~Hz})$, 7.33-7.40 (5H, m); ${ }^{13} \mathrm{C}$ NMR $\left(125.8 \mathrm{MHz}, \mathrm{CDCl}_{3}\right) \delta$ 9.5, 56.2, 74.9, 79.1, 80.3, 126.9, 128.72, 128.75, 138.8; MS (EI), $m / z$ (relative intensity) $286\left(\mathrm{M}^{+}, 3\right), 159$ (16), 145 (100); HRMS (EI) calcd for $\mathrm{C}_{11} \mathrm{H}_{11} \mathrm{OI}$ 285.9855, found; 285.9860 .

2 Okabe, M; Abe, M.; Tada, M. J. Org. Chem. 1982, 47, 1775. 


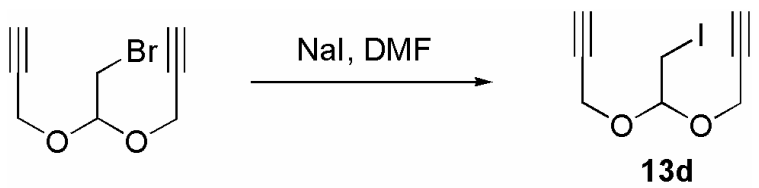

Iodoacetaldehyde Dipropargyl Acetal (13d). A mixture of bromoactaldehyde dipropargyl acetal ${ }^{3}$ (3.05 g, $14.1 \mathrm{mmol})$ and dry sodium iodide $(10.5 \mathrm{~g}, 70.3 \mathrm{mmol})$ in DMF $(20 \mathrm{~mL})$ was heated at $120{ }^{\circ} \mathrm{C}$ for $21 \mathrm{~h}$. The mixture was poured into water and extracted three times with ether. The organic layers were dried $\left(\mathrm{MgSO}_{4}\right)$ and concentrated in vacuo. The residue was purified by Kugelrohr distillation $\left(120{ }^{\circ} \mathrm{C} / 1 \mathrm{mmHg}\right)$ to give $\mathbf{1 3 d}\left(86 \%\right.$ yield): ${ }^{1} \mathrm{H}$ NMR $\left(500 \mathrm{MHz}, \mathrm{CDCl}_{3}\right) \delta 2.52(1 \mathrm{H}, \mathrm{t}, J=2.0 \mathrm{~Hz}), 3.33$ $(2 \mathrm{H}, \mathrm{d}, J=5.5 \mathrm{~Hz}), 4.30-4.38(4 \mathrm{H}, \mathrm{m}), 4.95(1 \mathrm{H}, \mathrm{t}, J=5.5 \mathrm{~Hz}) ;{ }^{13} \mathrm{C}$ NMR $\left(125.8 \mathrm{MHz}, \mathrm{CDCl}_{3}\right) \delta 4.3$, $54.4,75.2,78.9,99.8$.

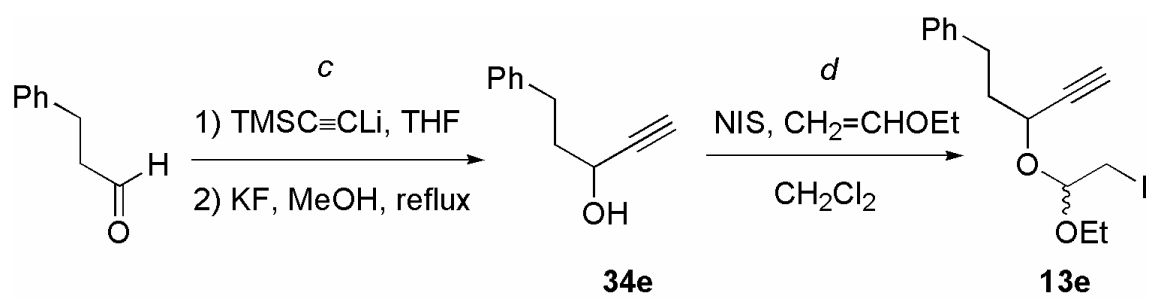

2-(1-Phenethylprop-2-ynyloxy)ethanol (34e); Typical Procedure for Step c. To a solution of (trimethylsilyl)acetylene $(2.70 \mathrm{~g}, 27.5 \mathrm{mmol})$ in THF $(19 \mathrm{~mL})$ at $0{ }^{\circ} \mathrm{C}$ was added BuLi (1.6 $\mathrm{M}$ in hexane) $(17.2 \mathrm{~mL}, 27.5 \mathrm{mmol})$. 3-Phenylpropanal $(3.35 \mathrm{~g}, 25.0 \mathrm{mmol})$ was added to the resulting solution of trimethylsilylethynyllithium at $-85^{\circ} \mathrm{C}$ over a period of $20 \mathrm{~min}$. The mixture was then allowed to warm to $0{ }^{\circ} \mathrm{C}$ over a period of $3 \mathrm{~h}$. The mixture was poured into water and extracted with ether $(3 \times 50 \mathrm{~mL})$. The combined organic layers were dried $\left(\mathrm{MgSO}_{4}\right)$ and concentrated in vacuo. The residue was dissolved in $66 \mathrm{~mL}$ of methanol and $6 \mathrm{~mL}$ of aqueous $3 \mathrm{~N} \mathrm{NaOH}$. After being stirred for $30 \mathrm{~min}$, the mixture was concentrated in vacuo to one fourth of its original volume. Brine $(50 \mathrm{~mL})$ was added to the concentrate. The mixture was extracted with ethyl acetate $(3 \times 50 \mathrm{~mL})$ and the combined extracts were dried $\left(\mathrm{MgSO}_{4}\right)$. The residue was purified by flash chromatography $\left(\mathrm{SiO}_{2}, 10 \%\right.$ ethyl acetate in hexane) to give $2.86 \mathrm{~g}$ (71\% yield) of $34 e^{4}$.

2-Ethoxy-1-iodo-3-oxa-4-(2-phenylethyl)-5-hexyne (13e); Typical Procedure for Step d. To a stirred suspension of $34 \mathrm{e}(1.17 \mathrm{~g}, 7.30 \mathrm{mmol})$ and $\mathrm{N}$-iodosuccinimide $(1.89 \mathrm{~g}, 13.5 \mathrm{mmol})$ in dry $\mathrm{CH}_{2} \mathrm{Cl}_{2}$ $(33 \mathrm{~mL})$ at $-20^{\circ} \mathrm{C}$ was added ethyl vinyl ether $(1.3 \mathrm{~mL}, 13.5 \mathrm{mmol})$ over a period of $10 \mathrm{~min}$. After being stirred at $-20{ }^{\circ} \mathrm{C}$ for $2 \mathrm{~h}$, the mixture was allowed to warm gradually to $0{ }^{\circ} \mathrm{C}$ and stirred for $16 \mathrm{~h}$. A saturated aqueous $\mathrm{NaHCO}_{3}(40 \mathrm{~mL})$ was added, and the aqueous layer was extracted with $\mathrm{CH}_{2} \mathrm{Cl}_{2}(3 \times$

3 Okabe, M.; Tamagawa, H.; Tada, M. Syn. Commun. 1983, 13, 373. 
$40 \mathrm{~mL})$. The combined extracts were washed with $10 \%$ aqueous sodium thiosulfate $(100 \mathrm{~mL})$ and dried $\left(\mathrm{MgSO}_{4}\right)$. The organic layer was concentrated in vacuo and purified by flash chromatography $\left(\mathrm{SiO}_{2}\right.$, $3 \%$ ethyl acetate in hexane) to afford $2.09 \mathrm{~g}$ (79\% yield) of $\mathbf{1 3 e}$ as a 1:1 mixture of diastereomers. 13e : ${ }^{1} \mathrm{H}$ NMR $\left(500 \mathrm{MHz}, \mathrm{C}_{6} \mathrm{D}_{6}\right) \delta 1.08(1.5 \mathrm{H}, \mathrm{t}, J=7.1 \mathrm{~Hz}), 1.18(1.5 \mathrm{H}, \mathrm{t}, J=7.1 \mathrm{~Hz}), 1.99-2.22(3 \mathrm{H}, \mathrm{m})$, 2.76-2.89 (2H, m), 3.09-3.17 (2H, m), $3.31(0.5 \mathrm{H}, \mathrm{qd}, J=7.1$ and $9.2 \mathrm{~Hz}), 3.41(0.5 \mathrm{H}, \mathrm{qd}, J=7.1$ and $9.2 \mathrm{~Hz}), 3.51(0.5 \mathrm{H}, \mathrm{qd}, J=7.1$ and $9.3 \mathrm{~Hz}), 3.73(0.5 \mathrm{H}, \mathrm{qd}, J=7.1$ and $9.3 \mathrm{~Hz}), 4.06(0.5 \mathrm{H}, \mathrm{td}, J=2.1$ and $6.4 \mathrm{~Hz}), 4.41(0.5 \mathrm{H}, \mathrm{td}, J=1.9$ and $6.4 \mathrm{~Hz}), 4.72(0.5 \mathrm{H}, \mathrm{m}), 4.91(0.5 \mathrm{H}, \mathrm{t}, J=5.0 \mathrm{~Hz}), 7.15-7.27$ $(5 \mathrm{H}, \mathrm{m}) ;{ }^{13} \mathrm{C}$ NMR $(125.8 \mathrm{MHz}) 5.6$ and 5.8, 14.9 and 15.2, 31.2 and 37.4, 62.73 and 62.77, 65.2 and 65.7, 74.3 and 74.7, 81.9 and 82.9, 99.6 and 101.1, 125.97 and 126.04, 128.37 and 128.42, 128.45 and $128.49,141.06$ and 141.17 .

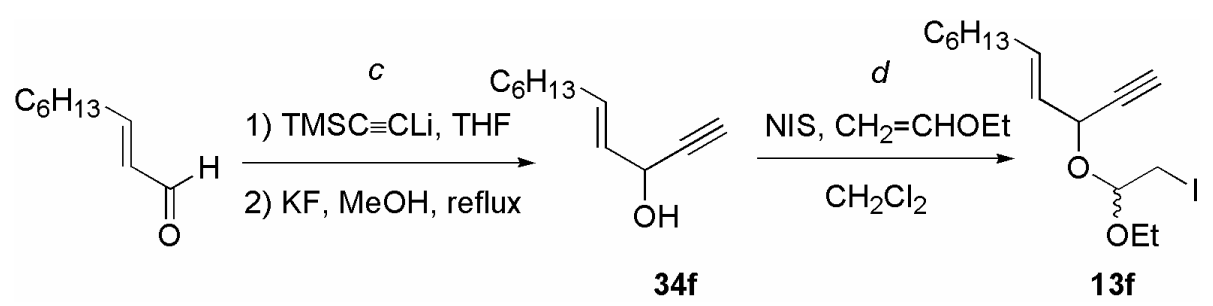

Undec-4-en-1-yn-3-ol (34f). The compound was prepared from trans-2-nonenal according to the procedure similar to that described above $($ step $c$ ). The crude product was purified by vacuum distillation $\left(60{ }^{\circ} \mathrm{C} / 0.15 \mathrm{mmHg}\right)$ to give $\mathbf{3 4 f}(73 \%$ yield $):{ }^{1} \mathrm{H} \mathrm{NMR}\left(500 \mathrm{MHz}, \mathrm{CDCl}_{3}\right) \delta 0.88(1 \mathrm{H}, \mathrm{t}, J=$ $6.9 \mathrm{~Hz}), 1.23-1.33(6 \mathrm{H}, \mathrm{m}), 1.39(2 \mathrm{H}, \mathrm{m}), 2.07(2 \mathrm{H}, \mathrm{m}), 2.56(1 \mathrm{H}, \mathrm{d}, J=2.2 \mathrm{~Hz}), 4.84(1 \mathrm{H}, \mathrm{dd}, J=0.8$ and $6.1 \mathrm{~Hz}), 5.61(1 \mathrm{H}, \mathrm{ddt}, J=1.4,6.1$, and $15.2 \mathrm{~Hz}), 5.92(1 \mathrm{H}, \mathrm{m}) ;{ }^{13} \mathrm{C} \mathrm{NMR}\left(125.8 \mathrm{MHz}, \mathrm{CDCl}_{3}\right) \delta$ $14.1,22.6,28.76,28.82,31.6,31.9,62.8,73.9,83.3,128.3,134.6$.

3-(1-Ethoxy-2-iodoethoxy)-undec-4-en-1-yne (13f). The compound was prepared from 34f according to the procedure similar to that described above (step $d$ ). The crude product was purified by flash chromatography $\left(\mathrm{SiO}_{2}, 5 \%\right.$ ethyl acetate in hexane) to give $\mathbf{1 3 f}(85 \%$ yield) as a $1: 1$ mixture of diastereomers. 13f: ${ }^{1} \mathrm{H}$ NMR $\left(500 \mathrm{MHz}, \mathrm{C}_{6} \mathrm{D}_{6}\right) \delta 0.95(1.5 \mathrm{H}, \mathrm{t}, J=7.0 \mathrm{~Hz}), 0.96(1.5 \mathrm{H}, \mathrm{t}, J=7.1 \mathrm{~Hz})$, $1.13(1.5 \mathrm{H}, \mathrm{t}, J=7.0 \mathrm{~Hz}), 1.16(1.5 \mathrm{H}, \mathrm{t}, J=7.0 \mathrm{~Hz}), 1.20-1.39(8 \mathrm{H}, \mathrm{m}), 1.96(2 \mathrm{H}, \mathrm{m}), 2.19(0.5 \mathrm{H}, \mathrm{dd}, J$ $=0.5$ and $2.2 \mathrm{~Hz}), 2.20(0.5 \mathrm{H}, \mathrm{dd}, J=0.5$ and $2.0 \mathrm{~Hz}), 3.14-3.19(1 \mathrm{H}, \mathrm{m}), 3.39(0.5 \mathrm{H}, \mathrm{qd}, J=7.1$, and $9.2 \mathrm{~Hz}), 3.48(0.5 \mathrm{H}, \mathrm{qd}, J=7.0 \mathrm{~Hz}), 3.52(0.5 \mathrm{H}, \mathrm{qd}, J=7.2 \mathrm{~Hz}), 3.62(0.5 \mathrm{H}, \mathrm{qd}, J=7.1$ and $9.3 \mathrm{~Hz})$, $4.78(0.5 \mathrm{H}, \mathrm{dd}, J=0.8$ and $6.6 \mathrm{~Hz}), 4.84(0.5 \mathrm{H}, \mathrm{t}, J=5.4 \mathrm{~Hz}), 4.96(0.5 \mathrm{H}, \mathrm{dd}, J=0.8 \mathrm{~Hz}), 5.00(0.5 \mathrm{H}$, t, $J=5.3 \mathrm{~Hz}), 5.68(1 \mathrm{H}, \mathrm{m}), 5.86(0.5 \mathrm{H}, \mathrm{m}), 5.96(0.5 \mathrm{H}, \mathrm{m}) ;{ }^{13} \mathrm{C} \mathrm{NMR}\left(125.8 \mathrm{MHz}, \mathrm{C}_{6} \mathrm{D}_{6}\right) 5.3 \mathrm{and} 5.4$, 14.0, 14.9 and 15.0, 22.66 and 22.69, 28.79 and 28.82, 28.9, 31.7, 31.97 and 32.00, 61.3 and 61.9, 66.45 and 66.50, 74.7 and 75.2, 81.1 and 81.9, 99.9 and 100.1, 126.80 and 126.85, 134.7 and 135.2; MS (EI), $m / z$ (relative intensity) $364\left(\mathrm{M}^{+}, 1\right), 363$ (8), 199 (100); HRMS (EI) calcd for $\mathrm{C}_{15} \mathrm{H}_{25} \mathrm{O}_{2} \mathrm{I} 364.0899$, found;

4 Pacheco, M.; Carmen, G., Org. Lett. 2005, 7, 1267. 
364.0907.

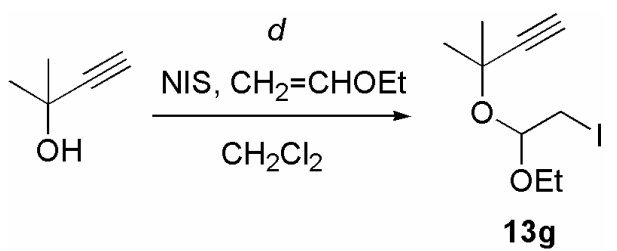

3-(1-Ethoxy-2-iodoethoxy)-3-methyl-1-butyne (13g). The compound was prepared from 2methylbut-3-yn-2-ol according to the procedure similar to that described above (step $d$ ). The crude product was purified by Kugelrohr distillation $\left(75^{\circ} \mathrm{C} / 0.05 \mathrm{mmHg}\right)$ to give $13 \mathrm{~g}$ ( $78 \%$ yield): ${ }^{1} \mathrm{H}$ NMR $\left(500 \mathrm{MHz}, \mathrm{C}_{6} \mathrm{D}_{6}\right) \delta 1.16(3 \mathrm{H}, \mathrm{t}, J=7.0 \mathrm{~Hz}), 1.41(1 \mathrm{H}, \mathrm{s}), 1.46(1 \mathrm{H}, \mathrm{s}), 2.10(1 \mathrm{H}, \mathrm{s}), 3.18-3.23(2 \mathrm{H}, \mathrm{m})$, $3.40(1 \mathrm{H}, \mathrm{qd}, J=7.1$ and $9.0 \mathrm{~Hz}), 3.57(1 \mathrm{H}, \mathrm{qd}, J=7.1$ and $9.0 \mathrm{~Hz}), 5.13(1 \mathrm{H}, \mathrm{t}, \quad J=5.6 \mathrm{~Hz}) ;{ }^{13} \mathrm{C} \mathrm{NMR}$ $\left(125.8 \mathrm{MHz}, \mathrm{C}_{6} \mathrm{D}_{6}\right) \delta$ 7.2, 15.0, 29.5, 30.1, 60.8, 70.3, 73.3, 85.6, 98.5; MS (CI), $\mathrm{m} / z$ (relative intensity) $283\left(\mathrm{MH}^{+}, 0.6\right), 237$ (88), 199 (100); HRMS (CI) calcd for $\mathrm{C}_{9} \mathrm{H}_{16} \mathrm{O}_{2} \mathrm{I}\left(\mathrm{MH}^{+}\right)$283.0195, found; 283.0187.

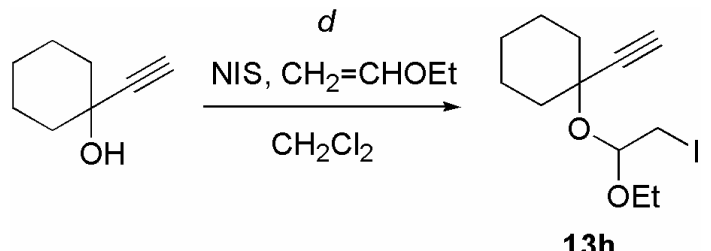

1-(1-Ethoxy-2-iodoethoxy)-1-ethynylcyclohexane (13h): The compound was prepared from 1ethynylcyclohexanol according to the procedure similar to that described above (step $d$ ). The crude product was purified by Kugelrohr distillation $\left(100-120{ }^{\circ} \mathrm{C} / 0.05 \mathrm{mmHg}\right)$ to give $13 \mathbf{h}\left(63 \%\right.$ yield): ${ }^{1} \mathrm{H}$ NMR $\left(300 \mathrm{MHz}, \mathrm{C}_{6} \mathrm{D}_{6}\right) \delta 1.10(1 \mathrm{H}, \mathrm{m}), 1.21(3 \mathrm{H}, \mathrm{t}, J=7.0 \mathrm{~Hz}), 1.42(1 \mathrm{H}, \mathrm{m}), 1.50-1.72(6 \mathrm{H}, \mathrm{m}), 1.88$ $(1 \mathrm{H}, \mathrm{m}), 2.04(1 \mathrm{H}, \mathrm{m}), 2.15(1 \mathrm{H}, \mathrm{s}), 3.25-3.28(2 \mathrm{H}, \mathrm{m}), 3.47(1 \mathrm{H}, \mathrm{m}), 3.68(1 \mathrm{H}, \mathrm{m}), 5.23(1 \mathrm{H}, \mathrm{dd}, J=4.7$ and 5.6 Hz); ${ }^{13} \mathrm{C}$ NMR $\left(125.8 \mathrm{MHz}, \mathrm{C}_{6} \mathrm{D}_{6}\right) \delta 8.0,15.3,23.1(2 \mathrm{C}), 25.3,38.6,39.0,61.4,74.4,75.7,84.8$, 98.2. Anal. Calcd for $\mathrm{C}_{12} \mathrm{H}_{19} \mathrm{O}_{2} \mathrm{I}$ : C, 44.74; H, 5.94. Found: C, 44.30; H, 5.87.

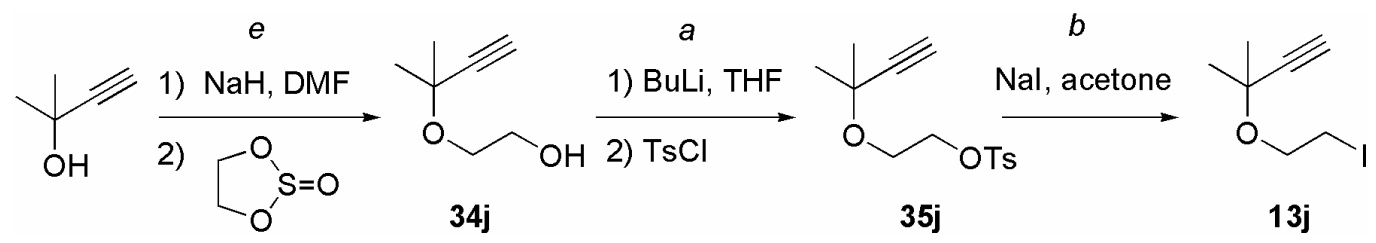

2-(1,1-Dimethylprop-2-ynyloxy)ethanol (34j); Typical Procedure for Step e. $\mathrm{NaH}(60 \%$ oil suspension) (1.20 g, $30.0 \mathrm{mmol}$ ) was added portionwise to a stirred solution of 2-methylbut-3-yn-2-ol $(2.15 \mathrm{~g}, 24.9 \mathrm{mmol})$ in DMF $(100 \mathrm{~mL})$ at room temperature and the mixture was stirred for $0.5 \mathrm{~h}$. To 
the resulting suspension was added glycol sulfite $(3.24 \mathrm{~g}, 30.0 \mathrm{mmol})$ over $5 \mathrm{~min}$. After being stirred for $1 \mathrm{~h}$ at room temperature, the mixture was poured into water and extracted three times with ether. The combined organic layers were washed successively with water $(\times 3)$ and brine, dried $\left(\mathrm{MgSO}_{4}\right)$, and concentrated in vacuo. The residue was purified by Kugelrohr distillation $\left(120^{\circ} \mathrm{C} / 20 \mathrm{mmHg}\right)$ to give $1.18 \mathrm{~g}\left(28 \%\right.$ yield) of 34j: ${ }^{1} \mathrm{H}$ NMR $\left(500 \mathrm{MHz}, \mathrm{CDCl}_{3}\right) \delta 1.49(6 \mathrm{H}, \mathrm{s}), 1.94(1 \mathrm{H}, \mathrm{br}$ ) $), 2.43(1 \mathrm{H}, \mathrm{s}), 3.66-$ $3.71(2 \mathrm{H}, \mathrm{m}), 3.72-3.78(2 \mathrm{H}, \mathrm{m}) ;{ }^{13} \mathrm{C} \mathrm{NMR}\left(125.8 \mathrm{MHz}, \mathrm{CDCl}_{3}\right) \delta 28.6,62.1,65.2,70.2,72.2,85.8$.

2-(1,1-Dimethylprop-2-ynyloxy)ethyl $p$-Toluenesulfonate (35j). The compound was prepared from 34j according to the procedure similar to that described above (step $a$ ). The crude product was purified by flash chromatography $\left(\mathrm{SiO}_{2}, 6-20 \%\right.$ ethyl acetate in hexane) to $\mathbf{3 5 j}$ (84\% yield): ${ }^{1} \mathrm{H}$ NMR $\left(500 \mathrm{MHz}, \mathrm{CDCl}_{3}\right) \delta 1.38(6 \mathrm{H}, \mathrm{s}), 2.39(1 \mathrm{H}, \mathrm{s}), 2.43(3 \mathrm{H}, \mathrm{s}), 3.70-3.75(2 \mathrm{H}, \mathrm{m}), 4.14-4.19(2 \mathrm{H}, \mathrm{m}), 7.33$ $(2 \mathrm{H}, \mathrm{d}, J=8.0 \mathrm{~Hz}), 7.80(2 \mathrm{H}, \mathrm{d}, J=8.0 \mathrm{~Hz}) ;{ }^{13} \mathrm{C} \mathrm{NMR}\left(125.8 \mathrm{MHz}, \mathrm{CDCl}_{3}\right) \delta 21.6,28.4,61.8,69.5$, $70.3,72.5,85.3,128.0,129.7,133.1,144.6$.

3-(2-Iodoethoxy)-3-methyl-1-butyne (13j). The compound was prepared from $\mathbf{3 5} \mathbf{j}$ according to the procedure similar to that described above (step $b$ ). The crude product was purified by Kugelrohr distillation $\left(140{ }^{\circ} \mathrm{C} / 14 \mathrm{mmHg}\right)$ to give $\mathbf{1 3 j}$ in $78 \%$ yield: ${ }^{1} \mathrm{H}$ NMR $\left(500 \mathrm{MHz}, \mathrm{CDCl}_{3}\right) \delta 1.48(6 \mathrm{H}, \mathrm{s}), 3.24$ $(2 \mathrm{H}, \mathrm{t}, J=6.9 \mathrm{~Hz}), 3.81(2 \mathrm{H}, \mathrm{t}, J=6.9 \mathrm{~Hz}) ;{ }^{13} \mathrm{C} \mathrm{NMR}\left(125.8 \mathrm{MHz}, \mathrm{CDCl}_{3}\right) \delta 3.6,28.7,65.3,70.4,72.3$, 85.7; MS (EI), $m / z$ (relative intensity) $238\left(\mathrm{M}^{+}, 19\right), 223$ (75), 155 (100); HRMS (EI) calcd for $\mathrm{C}_{7} \mathrm{H}_{11} \mathrm{OI}$, 237.9855, found; 237.9846 .

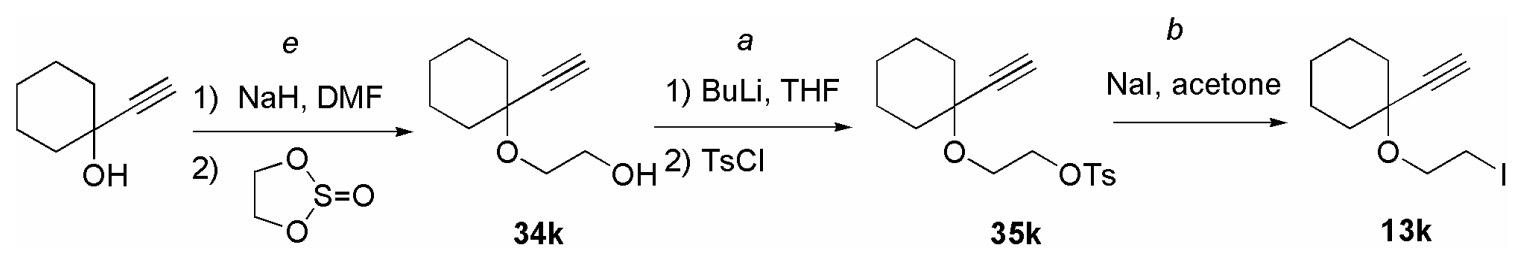

2-(1-Ethynylcyclohexyloxy)ethanol (34k). The compound was prepared from 1ethynylcyclohexanol according to the procedure similar to that described above (step $e$ ). The crude product was purified by Kugelrohr distillation $\left(100-110{ }^{\circ} \mathrm{C} / 0.5 \mathrm{mmHg}\right.$ ) to give $34 \mathbf{k}$ (39\% yield): ${ }^{1} \mathrm{H}$ NMR (500 MHz, $\left.\mathrm{CDCl}_{3}\right) \delta 1.27(1 \mathrm{H}, \mathrm{m}), 1.42-1.68(7 \mathrm{H}, \mathrm{m}), 1.84-1.90(2 \mathrm{H}, \mathrm{m}), 2.34(1 \mathrm{H}$, br s), 2.46 $(1 \mathrm{H}, \mathrm{s}), 3.64-3.68(2 \mathrm{H}, \mathrm{m}), 3.68-3.72(2 \mathrm{H}, \mathrm{m}) ;{ }^{13} \mathrm{C} \mathrm{NMR}\left(125.8 \mathrm{MHz}, \mathrm{CDCl}_{3}\right) \delta 22.6,25.3,37.0,62.1$, $64.2,73.6,73.9,85.0$.

2-(1-Ethynylcyclohexyloxy)ethyl $p$-Toluenesulfonate (35k). The compound was prepared from 34k according to the procedure similar to that described above (step $a$ ). The crude product was purified by flash chromatography ( $\mathrm{SiO}_{2}, 10-20 \%$ ethyl acetate in hexane) to give 35k (98\% yield): ${ }^{1} \mathrm{H}$ NMR (500 $\left.\mathrm{MHz}, \mathrm{CDCl}_{3}\right) \delta 1.24(1 \mathrm{H}, \mathrm{m}), 1.42-1.63(7 \mathrm{H}, \mathrm{m}), 1.75-1.83(2 \mathrm{H}, \mathrm{m}), 2.43(1 \mathrm{H}, \mathrm{s}), 2.44(3 \mathrm{H}, \mathrm{s}), 3.71-$ $3.76(2 \mathrm{H}, \mathrm{m}), 4.09-4.19(2 \mathrm{H}, \mathrm{m}), 7.33(2 \mathrm{H}, \mathrm{d}, J=8.3 \mathrm{~Hz}), 7.81(2 \mathrm{H}, \mathrm{d}, J=8.3 \mathrm{~Hz}) ;{ }^{13} \mathrm{C}$ NMR $(125.8$ $\left.\mathrm{MHz}, \mathrm{CDCl}_{3}\right) \delta 21.6,22.4,25.2,36.8,60.9,69.6,73.7,74.0,84.6,128.0,129.7,133.2,144.6$. 
1-Ethynyl-1-(2-iodoethoxy)cyclohexane (13k). The compound was prepared from 35k according to the procedure similar to that described above (step $b$ ). The crude product was purified Kugelrohr distillation (100-1 $\left.15{ }^{\circ} \mathrm{C} / 0.05 \mathrm{mmHg}\right)$ to give $\mathbf{1 3 k}\left(82 \%\right.$ yield): ${ }^{1} \mathrm{H} \mathrm{NMR}\left(500 \mathrm{MHz}, \mathrm{CDCl}_{3}\right) \delta 1.32(1 \mathrm{H}$, m), 1.46-1.73 (7H, m), 1.85-1.90 (2H, m), $2.48(1 \mathrm{H}, \mathrm{s}), 3.26(2 \mathrm{H}, \mathrm{t}, J=6.9 \mathrm{~Hz}), 3.83(2 \mathrm{H}, \mathrm{t}, J=6.9 \mathrm{~Hz})$; ${ }^{13} \mathrm{C}$ NMR $\left(125.8 \mathrm{MHz}, \mathrm{CDCl}_{3}\right) \delta 4.0,22.5,25.3,37.1,64.4,73.7,73.9,85.0$. Anal. Calcd for $\mathrm{C}_{10} \mathrm{H}_{15} \mathrm{OI}$ : C, 43.18; H, 5.44. Found: C, 42.81; H, 5.42.

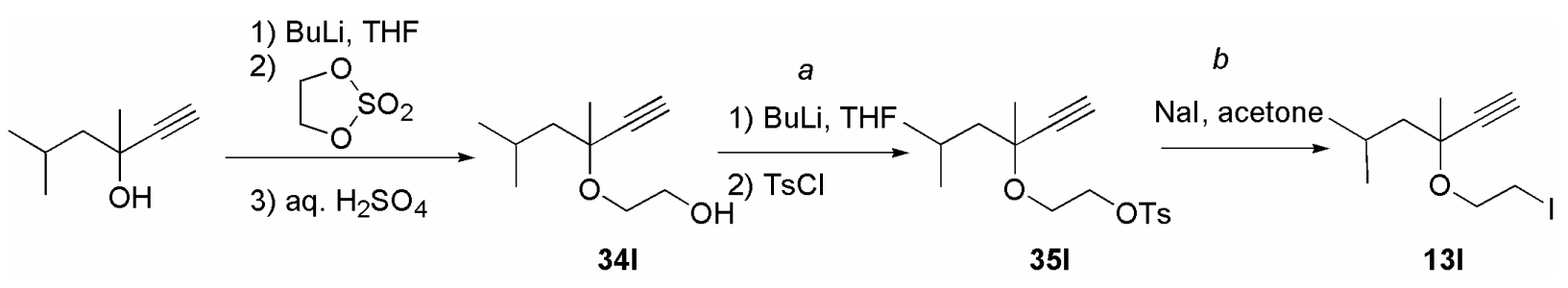

2-(1-Ethynyl-1,3-dimethylbutoxy)ethanol (34l). To a solution of 3,5-dimethyl-1-hexyne-3-ol $(3.03 \mathrm{~g}, 24.0 \mathrm{mmol})$ in THF $(55 \mathrm{~mL})$ at $-78{ }^{\circ} \mathrm{C}$ under argon atmosphere was added BuLi $(1.6 \mathrm{M}$ in hexane) $(16.5 \mathrm{~mL}, 26.4 \mathrm{mmol})$. The mixture was stirred at this temperature for $15 \mathrm{~min}$. A THF (25 $\mathrm{mL}$ ) solution of 1,3,2-dioxathilane 2,2-dioxide (3.29 g, $26.5 \mathrm{mmol})$ was added to the resulting solution of the alkoxide during $15 \mathrm{~min}$ at $-78{ }^{\circ} \mathrm{C}$. The reaction mixture was allowed to warm to room temperature during $4 \mathrm{~h}$, stirred at $40{ }^{\circ} \mathrm{C}$ for $45 \mathrm{~h}$, and then concentrated in vacuo. The residue was dissolved in ether $(130 \mathrm{~mL})$ and stirred vigorously with $20 \%$ aqueous $\mathrm{H}_{2} \mathrm{SO}_{4}(130 \mathrm{~mL})$ at room temperature for $23 \mathrm{~h}$. The mixture was diluted with ether $(150 \mathrm{~mL})$ and water $(150 \mathrm{~mL})$. The organic layer was separated, washed with brine, dried $\left(\mathrm{MgSO}_{4}\right)$, and concentrated in vacuo. Purification of the residue by flash chromatography $\left(\mathrm{SiO}_{2}, 5-30 \%\right.$ ethyl acetate in hexane) gave $2.65 \mathrm{~g}$ (65\% yield) of 34l: ${ }^{1} \mathrm{H}$ NMR (500 $\left.\mathrm{MHz}, \mathrm{CDCl}_{3}\right) \delta 0.95(3 \mathrm{H}, \mathrm{d}, J=6.6 \mathrm{~Hz}), 0.96(3 \mathrm{H}, \mathrm{d}, J=6.6 \mathrm{~Hz}), 1.41(3 \mathrm{H}, \mathrm{s}), 1.57(1 \mathrm{H}, \mathrm{dd}, J=5.8$ and $14.1 \mathrm{~Hz}), 1.62(1 \mathrm{H}, \mathrm{dd}, J=5.8$ and $14.1 \mathrm{~Hz}), 1.91(1 \mathrm{H}$, sept, $J=6.6 \mathrm{~Hz}), 2.13(1 \mathrm{H}, \mathrm{br}), 2.45(1 \mathrm{H}, \mathrm{s}), 3.61$ $(1 \mathrm{H}, \mathrm{m}), 3.65-3.71(3 \mathrm{H}, \mathrm{m}) ;{ }^{13} \mathrm{C} \mathrm{NMR}\left(125.8 \mathrm{MHz}, \mathrm{CDCl}_{3}\right) \delta 24.1,24.2,24.8,26.8,49.8,62.1,64.8$, $73.3,73.6,85.3$.

2-(1-Ethynyl-1,3-dimethylbutoxy)ethyl p-Toluenesulfonate (351). The compound was prepared from $34 \mathrm{l}$ according to the procedure similar to that described above (step $b$ ). The crude product was purified by flash chromatography $\left(\mathrm{SiO}_{2}, 10 \%\right.$ ethyl acetate in hexane) to give 351 ( $86 \%$ yield): ${ }^{1} \mathrm{H}$ NMR $\left(500 \mathrm{MHz}, \mathrm{CDCl}_{3}\right) \delta 0.91(3 \mathrm{H}, \mathrm{d}, J=6.7 \mathrm{~Hz}), 0.92(3 \mathrm{H}, \mathrm{d}, J=6.7 \mathrm{~Hz}), 1.35(3 \mathrm{H}, \mathrm{s}), 1.45-1.55(2 \mathrm{H}, \mathrm{m})$, $1.84(1 \mathrm{H}$, sept, $J=6.7 \mathrm{~Hz}), 2.42(1 \mathrm{H}, \mathrm{s}), 2.44(3 \mathrm{H}, \mathrm{s}), 3.67(1 \mathrm{H}, \mathrm{m}), 3.78(1 \mathrm{H}, \mathrm{m}), 4.15(2 \mathrm{H}, \mathrm{m}), 7.32$ $(2 \mathrm{H}, \mathrm{d}, J=8.2 \mathrm{~Hz}), 7.78(2 \mathrm{H}, \mathrm{d}, J=8.2 \mathrm{~Hz}) ;{ }^{13} \mathrm{C} \mathrm{NMR}\left(125.8 \mathrm{MHz}, \mathrm{CDCl}_{3}\right) \delta 21.6,24.0,24.2,24.7$, $26.6,49.7,61.4,69.5,73.5,73.8,84.8,128.0,129.7,133.2,144.6$.

3-(2-Iodoethoxy)-3,5-dimethyl-hex-1-yne (131). The compound was prepared from 35l according to the procedure similar to that described above (step $c$ ). The crude product was purified by flash chromatography $\left(\mathrm{SiO}_{2}, 5 \%\right.$ ethyl acetate in hexane) and Kugelrohr distillation $\left(75-80^{\circ} \mathrm{C} / 0.5 \mathrm{mmHg}\right)$ to 
give $13 \mathrm{I}$ (71\% yield): ${ }^{1} \mathrm{H}$ NMR $\left(500 \mathrm{MHz}, \mathrm{CDCl}_{3}\right) \delta 0.98(6 \mathrm{H}, \mathrm{t}, J=6.5 \mathrm{~Hz}), 1.43(3 \mathrm{H}, \mathrm{s}), 1.58(1 \mathrm{H}$, dd, $J=5.8$ and $12.5 \mathrm{~Hz}), 1.63(1 \mathrm{H}, \mathrm{dd}, J=6.4$ and $12.5 \mathrm{~Hz}), 1.95(1 \mathrm{H}$, septet, $J=6.5 \mathrm{~Hz}), 2.47(1 \mathrm{H}, \mathrm{s})$,

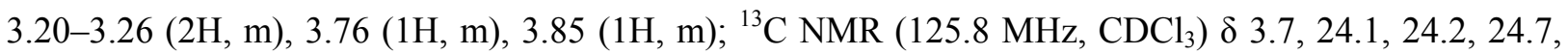
27.0, 49.9, 64.9, 73.4, 73.7, 85.1; MS (CI), $m / z$ (relative intensity) $281\left(\mathrm{MH}^{+}, 11\right), 155$ (36), 109 (100); HRMS (CI) calcd for $\mathrm{C}_{10} \mathrm{H}_{18} \mathrm{OI}\left(\mathrm{MH}^{+}\right)$281.0402, found; 281.0407.

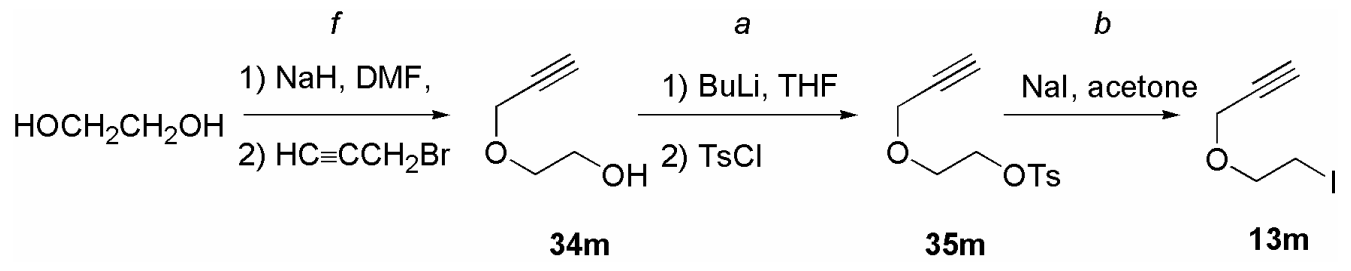

2-Prop-2-ynyloxyethanol (34m); Typical Procedure for Step $\boldsymbol{f}$. To a suspension of sodium hydride (60\% oil suspension, $166.0 \mathrm{mg}, 41.6 \mathrm{mmol})$ in THF $(80 \mathrm{~mL})$ at $0{ }^{\circ} \mathrm{C}$ under nitrogen atmosphere was added a THF $(100 \mathrm{~mL})$ solution of ethylene glycol $(10.3 \mathrm{~g}, 166 \mathrm{mmol})$ during $0.5 \mathrm{~h}$. The reaction mixture was stirred for $2 \mathrm{~h}$ at room temperature. To the resulting suspension at room temperature was added propargyl bromide $(2.8 \mathrm{~mL}, 38 \mathrm{mmol})$. The reaction mixture was heated under reflux for $6 \mathrm{~h}$ and then diluted with water $(80 \mathrm{~mL})$. The mixture was concentrated in vacuo and extracted with ethyl acetate $(4 \times 50 \mathrm{~mL})$. The combined organic layers were washed with brine, dried $\left(\mathrm{MgSO}_{4}\right)$, and concentrated in vacuo. Purification of the residue by Kugelrohr distillation $\left(3.0 \mathrm{mmHg}, 100-150{ }^{\circ} \mathrm{C}\right)$ gave $2.05 \mathrm{~g}$ (54\% yield) of $\mathbf{3 4 m}$. $^{5}$

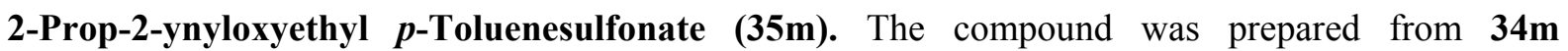
according to the procedure similar to that described above ( $\operatorname{step} a$ ). The crude product was purified by flash chromatography $\left(\mathrm{SiO}_{2}, 20 \%\right.$ ethyl acetate in hexane) to give $35 \mathrm{~m}$ (75\% yield): ${ }^{1} \mathrm{H}$ NMR (500 MHz, $\left.\mathrm{CDCl}_{3}\right) \delta 2.42(1 \mathrm{H}, \mathrm{t}, J=2.4 \mathrm{~Hz}), 2.45(3 \mathrm{H}, \mathrm{s}), 3.71-3.75(2 \mathrm{H}, \mathrm{m}), 4.12(2 \mathrm{H}, \mathrm{d}, J=2.4 \mathrm{~Hz}), 4.17-4.21$ $(2 \mathrm{H}, \mathrm{m}), 7.34(2 \mathrm{H}, \mathrm{d}, J=8.1 \mathrm{~Hz}), 7.80(2 \mathrm{H}, \mathrm{d}, J=8.1 \mathrm{~Hz}) ;{ }^{13} \mathrm{C} \mathrm{NMR}\left(125.8 \mathrm{MHz}, \mathrm{CDCl}_{3}\right) \delta 21.6,58.3$, $67.1,68.8,75.0,78.9,128.0,129.8,133.0,144.8$.

3-(2-Iodoethoxy)propyne (13m). The compound was prepared from $\mathbf{3 5 m}$ according to the procedure similar to that described above (step $b$ ). The crude product was purified by Kugelrohr distillation (104-110 $\left.{ }^{\circ} \mathrm{C} / 10 \mathrm{mmHg}\right)$ to give $13 \mathrm{~m}$ (73\% yield): ${ }^{1} \mathrm{H} \mathrm{NMR}\left(500 \mathrm{MHz}, \mathrm{CDCl}_{3}\right) \delta 2.45(1 \mathrm{H}, \mathrm{t}$, $J=2.4 \mathrm{~Hz}), 3.28(2 \mathrm{H}, \mathrm{t}, J=6.8 \mathrm{~Hz}), 3.81(2 \mathrm{H}, \mathrm{t}, J=6.8 \mathrm{~Hz}) 4.21(2 \mathrm{H}, \mathrm{d}, J=2.3 \mathrm{~Hz}) ;{ }^{13} \mathrm{C} \mathrm{NMR}(125.8$ $\left.\mathrm{MHz}, \mathrm{CDCl}_{3}\right) \delta 2.1,57.9,70.4,74.9,79.2$; $\mathrm{MS}(\mathrm{EI}), \mathrm{m} / \mathrm{z}$ (relative intensity) $210\left(\mathrm{M}^{+}, 3\right), 155(16), 58$ (100); HRMS (EI) calcd for $\mathrm{C}_{5} \mathrm{H}_{7} \mathrm{OI} 209.9542$, found; 209.9550.

\footnotetext{
5 Bovicelli, P.; Mincione, E.; Patamia, M. Syn. Commun. 1991, 21, 907.
} 


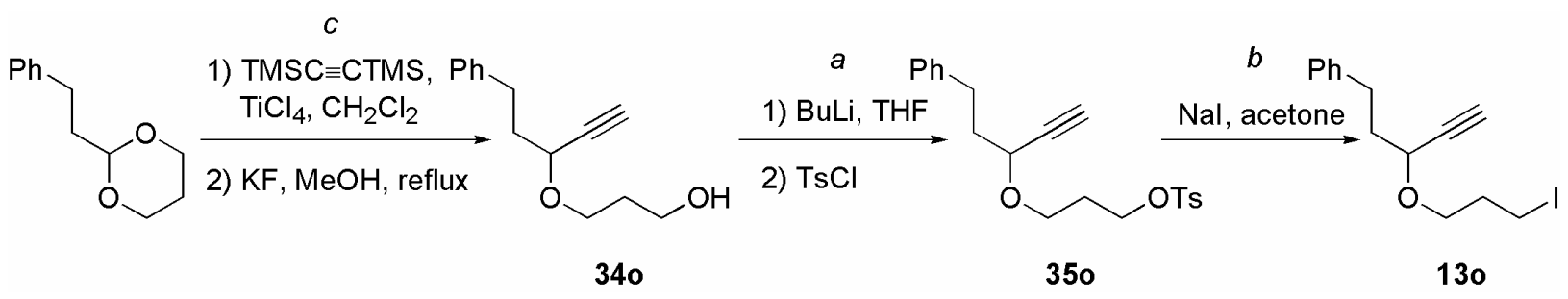

3-(1-Phenethylprop-2-ynyloxy)propan-1-ol (340). This compound was prepared from 2-(2phenylethyl)-1,3-dioxane according to a procedure similar to that described above (step $c$ ). The crude product was purified by flash chromatography $\left(\mathrm{SiO}_{2}, 10 \%\right.$ ethyl acetate in hexane) to give $\mathbf{3 4 0}(87 \%$ yield): ${ }^{1} \mathrm{H}$ NMR $\left(500 \mathrm{MHz}, \mathrm{CDCl}_{3}\right) \delta 1.80-2.15(5 \mathrm{H}, \mathrm{m}), 2.48(1 \mathrm{H}, \mathrm{d}, J=2.1 \mathrm{~Hz}), 2.79(2 \mathrm{H}, \mathrm{t}, J=8.1$ $\mathrm{Hz}), 3.54(1 \mathrm{H}, \mathrm{m}), 3.80(2 \mathrm{H}, \mathrm{t}, J=5.7 \mathrm{~Hz}), 3.94(1 \mathrm{H}, \mathrm{m}), 3.99(1 \mathrm{H}, \mathrm{m}), 7.17-7.24(3 \mathrm{H}, \mathrm{m}), 7.25-7.33$ $(2 \mathrm{H}, \mathrm{m})$.

3-(1-Phenethylprop-2-ynyloxy)propyl p-Toluenesulfonate (350). This compound was prepared from 340 according to a procedure similar to that described above (step $a$ ). The crude product was purified by flash chromatography $\left(\mathrm{SiO}_{2}, 6-20 \%\right.$ ethyl acetate in hexane) to give 350 (100\% yield): ${ }^{1} \mathrm{H}$ NMR $\left(500 \mathrm{MHz}, \mathrm{CDCl}_{3}\right) \delta 1.88-2.02(4 \mathrm{H}, \mathrm{m}), 2.40(3 \mathrm{H}, \mathrm{s}), 2.44(1 \mathrm{H}, \mathrm{d}, J=2.0 \mathrm{~Hz}), 2.70(2 \mathrm{H}, \mathrm{m}), 3.38$ $(1 \mathrm{H}, \mathrm{td}, J=6.0$ and $9.3 \mathrm{~Hz}), 3.97(1 \mathrm{H}, \mathrm{td}, J=6.0$ and $9.3 \mathrm{~Hz}), 3.91(1 \mathrm{H}, \mathrm{dt}, J=2.1$ and $6.6 \mathrm{~Hz}), 4.10-$ $4.18(2 \mathrm{H}, \mathrm{m}), 7.14-7.21(3 \mathrm{H}, \mathrm{m}), \quad 7.25-7.34(4 \mathrm{H}, \mathrm{m}), 7.79(2 \mathrm{H}, \mathrm{d}, J=8.3 \mathrm{~Hz})$.

[3-(3-Iodopropoxy)pent-4-ynyl]benzene (13o). This compound was prepared from 350 according to a procedure similar to that described above $(\operatorname{step} c$ ). The crude product was purified by flash chromatography ( $\mathrm{SiO}_{2}, 20 \%$ ethyl acetate in hexane) to give $\mathbf{1 3 h}\left(86 \%\right.$ yield): ${ }^{1} \mathrm{H}$ NMR (300 MHz, $\left.\mathrm{CDCl}_{3}\right) \delta 2.00-2.15(2 \mathrm{H}, \mathrm{m}), 2.47(1 \mathrm{H}, \mathrm{d}, J=2.1 \mathrm{~Hz}), 2.73-2.84(2 \mathrm{H}, \mathrm{m}), 3.26-3.34(2 \mathrm{H}, \mathrm{m}), 3.43(1 \mathrm{H}$, ddd, $J=5.3,6.5$ and $9.4 \mathrm{~Hz}), 3.80(1 \mathrm{H}, \mathrm{td}, J=5.7$ and $9.6 \mathrm{~Hz}), 4.00(1 \mathrm{H}, \mathrm{dt}, J=2.1$ and $6.0 \mathrm{~Hz}), 7.2-7.3$ $(5 \mathrm{H}, \mathrm{m}) ;{ }^{13} \mathrm{C} \mathrm{NMR}\left(125.8 \mathrm{MHz}, \mathrm{CDCl}_{3}\right) \delta 3.4,31.3,33.5,37.1,68.1,68.7,74.0,82.7,126.0,128.4$, 128.5, 141.2; MS (EI), $m / z$ (relative intensity) $328\left(\mathrm{M}^{+}, 3\right), 142$ (100), 91 (62); HRMS (EI) calcd for $\mathrm{C}_{14} \mathrm{H}_{17} \mathrm{OI} 328.0324$, found; 328.0326 .

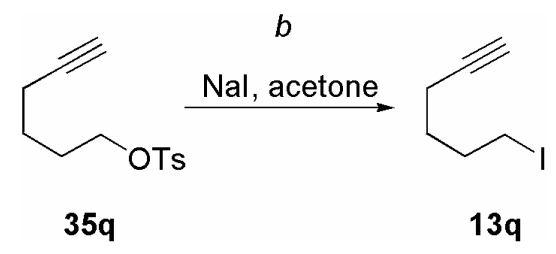

6-Iodo-1-hexyne (13q). This compound was prepared from $\mathbf{3 5 q}{ }^{6}$ according to a procedure similar to that described above (step $b$ ). The crude product was purified by Kugelrohr distillation (100-110

6 Harada, T.; Iwazaki, K.; Otani, T.; Oku, A. J. Org. Chem. 1998, 63, 9007. 
${ }^{\circ} \mathrm{C} / 10 \mathrm{mmHg}$ ) to give $\mathbf{1 3 q}{ }^{7}$ in $86 \%$ yield.

\section{Preparation of Diiodoalkynes 14.}

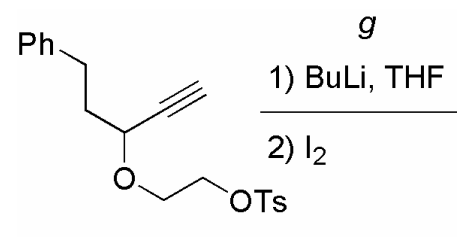

$35 a$

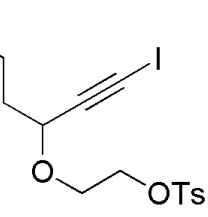

$36 \mathbf{a}$

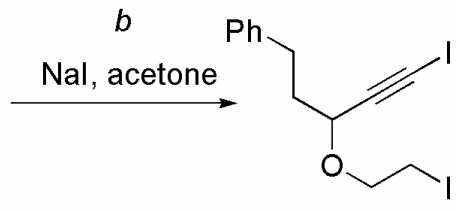

$14 a$

\section{2-(3-Iodo-1-phenethylprop-2-ynyloxy)ethyl p-Toluenesulfonate (36a); Typical Procedure for Step}

g. To a solution of 35a $(0.915 \mathrm{~g}, 2.55 \mathrm{mmol})$ in THF $(13 \mathrm{~mL})$ at $-40{ }^{\circ} \mathrm{C}$ was added BuLi $(1.6 \mathrm{M}$ in hexane) $(1.67 \mathrm{~mL}, 2.68 \mathrm{mmol})$. The reaction mixture was stirred for $2 \mathrm{~h}$. Then, a THF $(4 \mathrm{~mL})$ solution of $\mathrm{I}_{2}(0.680 \mathrm{~g}, 2.68 \mathrm{mmol})$ was added to the mixture at $-40{ }^{\circ} \mathrm{C}$. After being stirred for $15 \mathrm{~min}$, the mixture was poured into a saturated aqueous $\mathrm{NaHCO}_{3}(100 \mathrm{~mL})$ and extracted with ethyl acetate $(3 \times$ $50 \mathrm{~mL})$. The combined organic layers were washed with $10 \%$ aqueous $\mathrm{Na}_{2} \mathrm{~S}_{2} \mathrm{O}_{3}(100 \mathrm{~mL})$, dried $\left(\mathrm{Na}_{2} \mathrm{SO}_{4}\right)$, and concentrated in vacuo. Purification of the residue by flash chromatography $\left(\mathrm{SiO}_{2}, 10 \%\right.$ ethyl acetate in hexane) afforded $1.17 \mathrm{~g}$ (95\% yield) of 36a: ${ }^{1} \mathrm{H} \mathrm{NMR}\left(500 \mathrm{MHz}, \mathrm{CDCl}_{3}\right) \delta 1.86-2.00$ $(2 \mathrm{H}, \mathrm{m}), 2.41(3 \mathrm{H}, \mathrm{s}), 2.63-2.73(2 \mathrm{H}, \mathrm{m}), 3.55(1 \mathrm{H}, \mathrm{ddd}, J=4.0,6.3$, and $11.1 \mathrm{~Hz}), 3.88(1 \mathrm{H}, \mathrm{ddd}, J=$ 3.6, 5.1, and 11.1 Hz), $4.09(1 \mathrm{H}, \mathrm{t}, J=6.8 \mathrm{~Hz}), 4.15-4.23(2 \mathrm{H}, \mathrm{m}), 7.13-7.22(3 \mathrm{H}, \mathrm{m}), 7.25-7.30(2 \mathrm{H}$, m), $7.33(2 \mathrm{H}, \mathrm{d}, J=8.3 \mathrm{~Hz}), 7.81(2 \mathrm{H}, \mathrm{d}, J=8.3 \mathrm{~Hz}) ;{ }^{13} \mathrm{C}$ NMR $\left(125.8 \mathrm{MHz}, \mathrm{CDCl}_{3}\right) \delta 2.9,21.6,31.1$, $37.0,66.3,69.0,70.5,93.0,126.0,128.0,128.4,128.5,129.8,133.0,140.9,144.8$.

[5-Iodo-3-(2-iodoethoxy)pent-4-ynyl]benzene (14a). This compound was prepared from 36a according to a procedure similar to that described above (step $b$ ). The crude product was purified by Kugelrohr distillation $\left(160-170{ }^{\circ} \mathrm{C} / 0.05 \mathrm{mmHg}\right)$ to give $14 \mathrm{a}\left(80 \%\right.$ yield): ${ }^{1} \mathrm{H}$ NMR $\left(500 \mathrm{MHz}, \mathrm{CDCl}_{3}\right) \delta$ 1.99-2.14 (2H, m), 2.77-2.85 (2H, m), 3.25-3.32 (2H, m), $3.66(1 \mathrm{H}, \mathrm{dt}, J=7.0$ and $10.5 \mathrm{~Hz}), 3.98(1 \mathrm{H}$, ddd, $J=6.1,7.0$, and $10.5 \mathrm{~Hz}), 4.19(1 \mathrm{H}, \mathrm{dd}, J=6.0$, and $7.2 \mathrm{~Hz}), 7.20-7.32(5 \mathrm{H}, \mathrm{m}) ;{ }^{13} \mathrm{C}$ NMR $(125.8$ $\mathrm{MHz}, \mathrm{CDCl}_{3}$ ) $\delta 2.7,2.8,31.2,37.2,69.5,70.1,93.4,126.0,128.4,128.5,141.0$; MS (CI), $\mathrm{m} / \mathrm{z}$ (relative intensity) $441\left(\mathrm{MH}^{+}, 2\right), 395$ (38), 269 (100); HRMS (CI) calcd for $\mathrm{C}_{13} \mathrm{H}_{15} \mathrm{I}_{2} \mathrm{O}\left(\mathrm{MH}^{+}\right)$440.9212, found; 440.9225.

7 Jackson, P. M.; Moody, C. J.; Shah, P. J. Chem. Soc., Perkin Trans. 1 1990, 2909. 


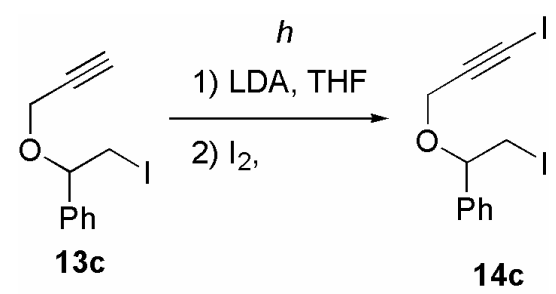

1,6-Diiodo-3-oxa-2-phenyl-5-hexyne (14c); Typical Procedure for Step $h$. To a solution of 13c $(2.15 \mathrm{~g}, 7.50 \mathrm{mmol})$ in THF $(15 \mathrm{~mL})$ at $0{ }^{\circ} \mathrm{C}$ was added LDA $(0.57 \mathrm{M}$ solution in THF) $(16 \mathrm{~mL}, 9.1$ $\mathrm{mmol})$. The reaction mixture was stirred for $30 \mathrm{~min}$. Then, a THF $(5.0 \mathrm{~mL})$ solution of $\mathrm{I}_{2}(2.28 \mathrm{~g}$, $9.00 \mathrm{mmol}$ ) was added to the mixture at $-20^{\circ} \mathrm{C}$. After being stirred for $15 \mathrm{~min}$, the mixture was poured into a saturated aqueous $\mathrm{NaHCO}_{3}(100 \mathrm{~mL})$ and extracted with ethyl acetate $(3 \times 50 \mathrm{~mL})$. The combined organic layers were washed with $10 \%$ aqueous $\mathrm{Na}_{2} \mathrm{~S}_{2} \mathrm{O}_{3}(100 \mathrm{~mL})$, dried $\left(\mathrm{MgSO}_{4}\right)$, and concentrated in vacuo. Purification of the residue by flash chromatography $\left(\mathrm{SiO}_{2}, 50 \%\right.$ toluene in hexane) afforded $1.49 \mathrm{~g}$ (48\% yield) of 14c: ${ }^{1} \mathrm{H}$ NMR (300 MHz, $\left.\mathrm{CDCl}_{3}\right), \delta 3.35-3.46(2 \mathrm{H}, \mathrm{m}), 4.12(1 \mathrm{H}$, d, $J=15.8 \mathrm{~Hz}), 4.37(1 \mathrm{H}, \mathrm{d}, J=15.8 \mathrm{~Hz}), 4.67(1 \mathrm{H}, \mathrm{dd}, J=5.2$ and $7.7 \mathrm{~Hz}), 7.32-7.44(5 \mathrm{H}, \mathrm{m}) ;{ }^{13} \mathrm{C}$ NMR (125.8 MHz, $\left.\mathrm{CDCl}_{3}\right) \delta 3.5,9.6,57.9,80.5,126.8,128.8$ (2C). 138.7.

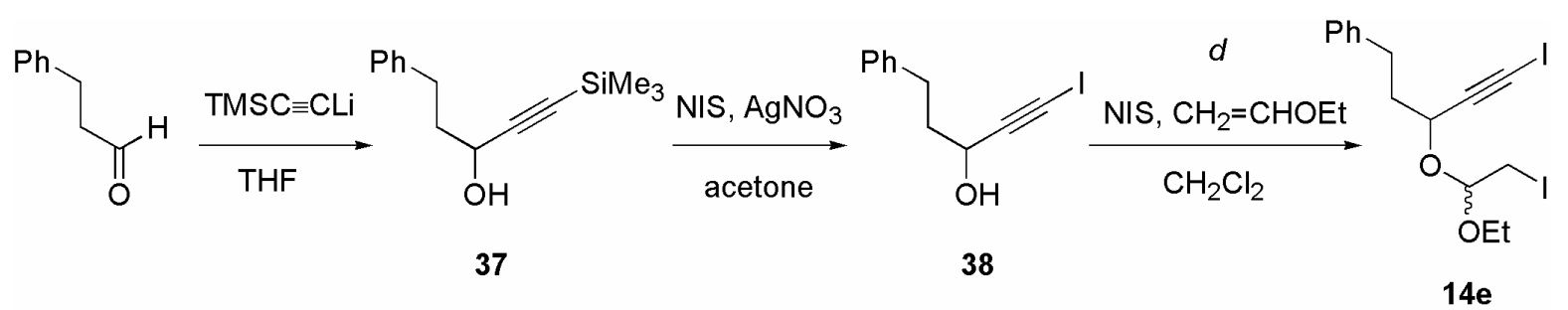

5-Phenyl-1-trimethylsilylpent-1-yn-3-ol (37). To a solution of ethynyltrimethylsilane $(3.9 \mathrm{~mL}, 28$ mmol) in THF $(25 \mathrm{~mL})$ at $0{ }^{\circ} \mathrm{C}$ was added BuLi (1.6 M in hexane) $(17.2 \mathrm{~mL}, 28 \mathrm{mmol})$. After being stirred at $-85^{\circ} \mathrm{C}$ for $30 \mathrm{~min}, 3$-phenylpropanal $(3.35 \mathrm{~g}, 25.0 \mathrm{mmol})$ was added into the resulting solution of trimethylsilylethynyllithium over a period of $10 \mathrm{~min}$. The mixture was then allowed to warm to -20 ${ }^{\circ} \mathrm{C}$ over a period of $3 \mathrm{~h}$. The mixture was poured into water and extracted with ether $(3 \times 50 \mathrm{~mL})$. The combined organic layers were dried $\left(\mathrm{MgSO}_{4}\right)$ and concentrated in vacuo. The residue was purified by flash chromatography $\left(\mathrm{SiO}_{2}, 7 \%\right.$ ethyl acetate in hexane) to give $5.61 \mathrm{~g}\left(97 \%\right.$ yield) of $37:{ }^{1} \mathrm{H}$ NMR $\left(300 \mathrm{MHz}, \mathrm{CDCl}_{3}\right) \delta 0.21(9 \mathrm{H}, \mathrm{s}), 2.00-2.12(2 \mathrm{H}, \mathrm{m}), 2.82(2 \mathrm{H}, \mathrm{t}, J=7.8 \mathrm{~Hz}), 4.38(1 \mathrm{H}, \mathrm{t}, J=6.6 \mathrm{~Hz})$, 7.19-7.34 (5H, m); ${ }^{13} \mathrm{C}$ NMR $\left(125.8 \mathrm{MHz}, \mathrm{CDCl}_{3}\right) \delta-0.1,31.4,39.2,62.2,89.1,106.5,126.0,128.4$, $128.5,141.3$.

1-Iodo-5-phenylpent-1-yn-3-ol (38). To a solution of $37(3.49 \mathrm{~g}, 15.0 \mathrm{mmol})$ in dry acetone (92 $\mathrm{mL}$ ) at room temperature was added $\mathrm{AgNO}_{3}(66 \mathrm{mg}, 0.4 \mathrm{mmol})$ and $N$-iodosuccinimide $(526 \mathrm{mg}, 2.3$ mmol). The reaction vessel was wrapped by aluminum foil to avoid light. After being stirred at room temperature for $1 \mathrm{~h}$, the reaction mixture was filtered. The filtrate was concentrated in vacuo. The 
residue was diluted with ether $(50 \mathrm{~mL})$ and poured into water $(50 \mathrm{~mL})$. The mixture was extracted with ether $(3 \times 40 \mathrm{~mL})$. The combined organic layers were washed with $10 \%$ aqueous $\mathrm{Na}_{2} \mathrm{~S}_{2} \mathrm{O}_{3}(100 \mathrm{~mL})$ and brine $(50 \mathrm{~mL})$, dried $\left(\mathrm{MgSO}_{4}\right)$, and concentrated in vacuo. The residue was dissolved in methanol $(36 \mathrm{~mL})$ and $3 \mathrm{~N}$ aqueous $\mathrm{Na}_{2} \mathrm{CO}_{3}(3.6 \mathrm{~mL})$. After being stirred for $15 \mathrm{~min}$, the mixture was concentrated in vacuo to one fourth of its original volume followed by addition of water $(50 \mathrm{~mL})$. The mixture was extracted with ether $(3 \times 40 \mathrm{~mL})$. The combined organic layers were washed with $10 \%$ aqueous $\mathrm{Na}_{2} \mathrm{~S}_{2} \mathrm{O}_{3}(100 \mathrm{~mL})$ and brine $(50 \mathrm{~mL})$, dried $\left(\mathrm{MgSO}_{4}\right)$, and concentrated in vacuo to afford 4.41 $\mathrm{g}(101 \%$ yield $)$ of $\mathbf{3 8}$, which was used in the following reaction without further purification. $38:{ }^{1} \mathrm{H}$ NMR (300 MHz, $\left.\mathrm{CDCl}_{3}\right) \delta 2.01-2.09(2 \mathrm{H}, \mathrm{m}), 2.82(2 \mathrm{H}, \mathrm{m}), 4.52(1 \mathrm{H}, \mathrm{t}, J=6.5 \mathrm{~Hz}), 7.20-7.35(5 \mathrm{H}, \mathrm{m})$; ${ }^{13} \mathrm{C}$ NMR $\left(125.8 \mathrm{MHz}, \mathrm{CDCl}_{3}\right) \delta 2.0,31.2,39.2,63.3,95.4,126.1,128.5,128.5,141.0$.

2-Ethoxy-1,6-diiodo-3-oxa-4-(2-phenylethyl)-5-hexyne (14e). The compound was prepared from 38 according to a procedure similar to that described above ( $\operatorname{step} d$ ). The crude product was purified by flash chromatography $\left(\mathrm{SiO}_{2}, 5 \%\right.$ ethyl acetate in hexane) to give 14e as a 1:1 mixture of diastereomers in 87\% yield. 14e: ${ }^{1} \mathrm{H}$ NMR (300 MHz, $\left.\mathrm{C}_{6} \mathrm{D}_{6}\right) \delta 1.05(1.5 \mathrm{H}, \mathrm{t}, J=7.0 \mathrm{~Hz}), 1.18(1.5 \mathrm{H}, \mathrm{t}, J=7.0 \mathrm{~Hz})$, 1.92-2.16 (2H, m), 2.70-2.86 (2H, m), $3.06(2 \mathrm{H}, \mathrm{dd}, J=5.0$ and $11.4 \mathrm{~Hz}), 3.30(2 \mathrm{H}, \mathrm{m}), 3.48(0.5 \mathrm{H}, \mathrm{m})$, $3.68(0.5 \mathrm{H}, \mathrm{m}), 4.12(0.5 \mathrm{H}, \mathrm{t}, J=6.4 \mathrm{~Hz}), 4.51(0.5 \mathrm{H}, \mathrm{m}), 4.65(0.5 \mathrm{H}, \mathrm{t}, J=5.2 \mathrm{~Hz}), 5.00(0.5 \mathrm{H}, \mathrm{t}, J=$ $5.0 \mathrm{~Hz}), 7.11-7.22(5 \mathrm{H}, \mathrm{m}) ;{ }^{13} \mathrm{C} \mathrm{NMR}\left(125.8 \mathrm{MHz}, \mathrm{CDCl}_{3}\right) \delta 3.0$ and 3.3, 5.5 and 5.8, 14.9 and 15.2, 31.19 and 31.22, 37.2 and 37.4, 62.8, 66.7 and 67.5, 93.0 and 93.8, 99.7 and 101, 2, 126.0 and 126.1, 128.37 and 128.42, 128.45 and 128.49, 140.9 and 141.4. Anal. Calcd for $\mathrm{C}_{15} \mathrm{H}_{18} \mathrm{O}_{2} \mathrm{I}_{2}: \mathrm{C}, 37.21 ; \mathrm{H}, 3.75$. Found: C, 36.85; H, 3.73.

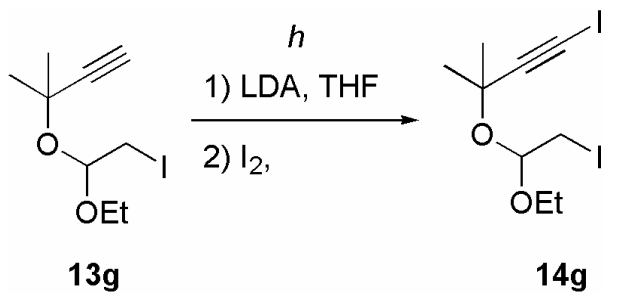

3-(1-Ethoxy-2-iodoethoxy)-1-iodo-3-methyl-1-butyne (14g). This compound was prepared from 13g according to a procedure similar to that described above (step $h$ ). The crude product was purified by flash chromatography $\left(\mathrm{SiO}_{2}, 5 \%\right.$ ethyl acetate in hexane) and subsequent Kugelrohr distillation (115$120{ }^{\circ} \mathrm{C} / 0.2 \mathrm{mmHg}$ ) to give $\mathbf{1 4 g}\left(61 \%\right.$ yield): ${ }^{1} \mathrm{H} \mathrm{NMR}\left(500 \mathrm{MHz}, \mathrm{C}_{6} \mathrm{D}_{6}\right) \delta 1.15(3 \mathrm{H}, \mathrm{t}, J=7.0 \mathrm{~Hz}), 1.34$ $(3 \mathrm{H}, \mathrm{s}), 1.40(3 \mathrm{H}, \mathrm{s}), 3.12-3.16(2 \mathrm{H}, \mathrm{m}), 3.37(1 \mathrm{H}, \mathrm{qd}, J=7.0$, and $9.1 \mathrm{~Hz}), 3.53(1 \mathrm{H}, \mathrm{qd}, J=7.1$, and $9.1 \mathrm{~Hz}), 5.04(1 \mathrm{H}, \mathrm{t}, J=5.0 \mathrm{~Hz}) ;{ }^{13} \mathrm{C} \mathrm{NMR}\left(125.8 \mathrm{MHz}, \mathrm{C}_{6} \mathrm{D}_{6}\right) \delta$ 2.7, 7.2, 15.0, 29.9, 29.8, 31.0, 61.1, 72.0, 96.7, 98.6. Anal. Calcd for $\mathrm{C}_{9} \mathrm{H}_{14} \mathrm{O}_{2} \mathrm{I}_{2}$ : C, 26.49; H, 3.46. Found: C, 26.48; H, 3.67. 


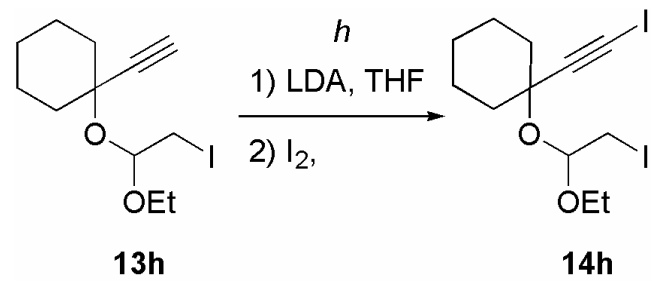

1-(1-Ethoxy-2-iodoethoxy)-1-iodoethynylcyclohexane (14h). This compound was prepared from 13h according to a procedure similar to that described above (step $h$ ). The crude product was purified by flash chromatography $\left(\mathrm{SiO}_{2}, 3 \%\right.$ ethyl acetate in hexane) to give $\mathbf{1 4 h}$ (55\% yield): ${ }^{1} \mathrm{H}$ NMR (500 $\left.\mathrm{MHz}, \mathrm{C}_{6} \mathrm{D}_{6}\right) \delta 1.05(1 \mathrm{H}, \mathrm{m}), 1.18(3 \mathrm{H}, \mathrm{t}, J=7.0 \mathrm{~Hz}), 1.34(1 \mathrm{H}, \mathrm{m}), 1.42-1.66(6 \mathrm{H}, \mathrm{m}), 1.81(1 \mathrm{H}, \mathrm{m})$, $1.96(1 \mathrm{H}, \mathrm{m}), 3.18(2 \mathrm{H}, \mathrm{m}), 3.41(1 \mathrm{H}, \mathrm{m}), 3.60(1 \mathrm{H}, \mathrm{m}), 5.11(1 \mathrm{H}, \mathrm{dd}, J=4.6$ and $5.4 \mathrm{~Hz}) ;{ }^{13} \mathrm{C} \mathrm{NMR}$ $\left(125.8 \mathrm{MHz}, \mathrm{C}_{6} \mathrm{D}_{6}\right) \delta 3.9,7.7,15.1,22.9,25.1,31.7,38.5,38.7,61.5,61.6,76.0,98.1$. Anal. Calcd for $\mathrm{C}_{12} \mathrm{H}_{18} \mathrm{O}_{2} \mathrm{I}_{2}$ : C, 32.17; H, 4.05. Found: C, 32.37; H, 4.15.

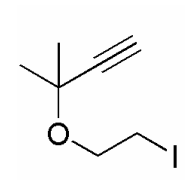

13j

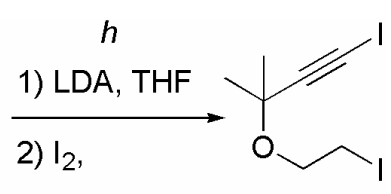

$14 \mathrm{j}$

1-Iodo-3-(2-iodoethoxy)-3-methyl-1-butyne (14j). This compound was prepared from 13j according to the procedure similar to that described above (step $h$ ). The crude product was purified by flash chromatography $\left(\mathrm{SiO}_{2}, 10 \%\right.$ ethyl acetate hexane) and Kugelrohr distillation $\left(100-110{ }^{\circ} \mathrm{C} / 0.05\right.$ $\mathrm{mmHg}$ ) to give $\mathbf{1 4 j}$ (33\% yield): ${ }^{1} \mathrm{H}$ NMR $\left(500 \mathrm{MHz}, \mathrm{CDCl}_{3}\right) \delta 1.46(6 \mathrm{H}, \mathrm{s}), 3.23(2 \mathrm{H}, \mathrm{t}, J=7.0 \mathrm{~Hz})$, $3.79(2 \mathrm{H}, \mathrm{t}, J=7.0 \mathrm{~Hz}) ;{ }^{13} \mathrm{C}$ NMR $\left(125.8 \mathrm{MHz}, \mathrm{CDCl}_{3}\right) \delta$ 0.8, 3.6, 28.8, 65.5, 72.1, 96.6; ; MS (EI), $m / z$ (relative intensity) $364\left(\mathrm{M}^{+}, 10\right), 349$ (100), 193 (48); HRMS (EI) calcd for $\mathrm{C}_{7} \mathrm{H}_{10} \mathrm{OI}_{2} 363.8821$, found; 363.8830 .

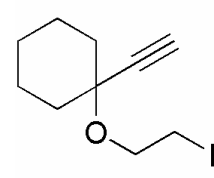

$13 k$

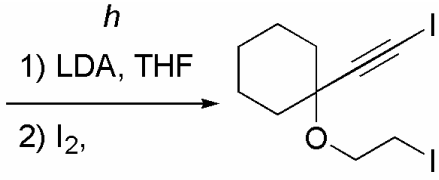

$14 \mathrm{k}$

1-(2-Iodoethoxy)-1-iodoethynylcyclohexane (14k). The compound was prepared from 13k according to the procedure similar to that described above ( $\operatorname{step} h$ ). The crude product was purified by flash chromatography $\left(\mathrm{SiO}_{2}, 5 \%\right.$ ethyl acetate hexane) and Kugelrohr distillation $\left(130^{\circ} \mathrm{C} / 0.05 \mathrm{mmHg}\right)$ to give $14 \mathbf{j}$ (27\% yield): ${ }^{1} \mathrm{H}$ NMR $\left(500 \mathrm{MHz}, \mathrm{CDCl}_{3}\right) \delta 1.30(1 \mathrm{H}, \mathrm{m}), 1.44-1.73(7 \mathrm{H}, \mathrm{m}), 1.82-1.93(2 \mathrm{H}$, 
m), $3.25(2 \mathrm{H}, \mathrm{t}, J=6.7 \mathrm{~Hz}), 3.81(2 \mathrm{H}, \mathrm{t}, J=6.7 \mathrm{~Hz}) ;{ }^{13} \mathrm{C} \mathrm{NMR}\left(125.8 \mathrm{MHz}, \mathrm{CDCl}_{3}\right) \delta 1.5,3.9,22.6$, 25.2, 37.2, 64.6, 75.6, 96.2. Anal. Calcd for $\mathrm{C}_{10} \mathrm{H}_{14} \mathrm{OI}_{2}$ : C, 29.73; H, 3.49. Found: C, 29.73; H, 3.49.

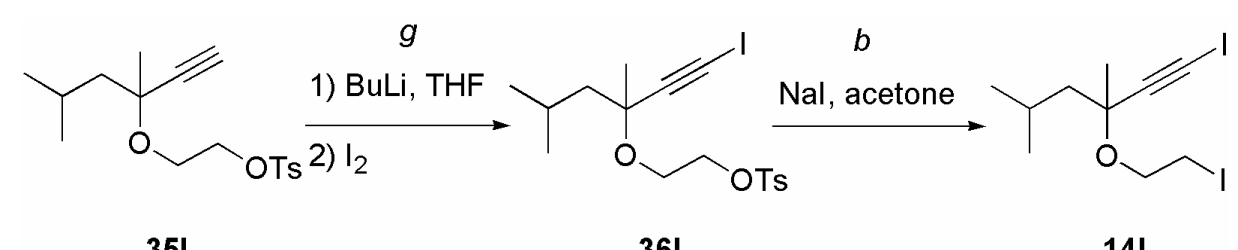

35I

$36 \mathbf{I}$

14 I

2-(1-Eodoethynyl-1,3-dimethylbutoxy)ethyl $p$-Toluenesulfonate (361). This compound was prepared from $35 \mathrm{I}$ according to the procedure similar to that described above (step $g$ ). The crude product was purified by flash chromatography $\left(\mathrm{SiO}_{2}, 10 \%\right.$ ethyl acetate in hexane) to give $\mathbf{3 6 1}$ ( $76 \%$ yield): ${ }^{1} \mathrm{H}$ NMR $\left(500 \mathrm{MHz}, \mathrm{CDCl}_{3}\right) \delta 0.86-0.92(6 \mathrm{H}, \mathrm{m}), 1.32(3 \mathrm{H}, \mathrm{s}), 1.44-1.53(2 \mathrm{H}, \mathrm{m}), 1.80(1 \mathrm{H}$, sept, $J=6.6 \mathrm{~Hz}), 2.44(3 \mathrm{H}, \mathrm{s}), 3.63-3.80(2 \mathrm{H}, \mathrm{m}), 4.10-4.16(2 \mathrm{H}, \mathrm{m}), 7.33(2 \mathrm{H}, \mathrm{d}, J=8.2 \mathrm{~Hz}), 7.78$ (2H, d, $J$ $=8.2 \mathrm{~Hz}) ;{ }^{13} \mathrm{C} \mathrm{NMR}\left(125.8 \mathrm{MHz}, \mathrm{CDCl}_{3}\right) \delta 1.8,21.6,23,9,24.1,24.7,26.6,49.8,61.6,69.5,75.2,95.9$, $127.9,129.8,133.1,144.6$.

1-Iodo-3-(2-iodoethoxy)-3,5-dimethylhex-1-yne (14I): The compound was prepared from 361 according to the procedure similar to that described above (step $b$ ). The crude product was purified by flash chromatography ( $\mathrm{SiO}_{2}, 5 \%$ ethyl acetate in hexane) to give 141 (84\% yield): ${ }^{1} \mathrm{H} \mathrm{NMR} \mathrm{(500} \mathrm{MHz,}$ $\left.\mathrm{CDCl}_{3}\right) \delta 0.96(3 \mathrm{H}, \mathrm{d}, J=6.7 \mathrm{~Hz}), 0.97(3 \mathrm{H}, \mathrm{d}, J=6.7 \mathrm{~Hz}), 1.41(3 \mathrm{H}, \mathrm{s}), 1.55(1 \mathrm{H}, \mathrm{dd}, J=5.6$ and 14.0 $\mathrm{Hz}), 1.61(1 \mathrm{H}, \mathrm{dd}, J=5.6$ and $14.0 \mathrm{~Hz}), 1.91(1 \mathrm{H}$, sept, $J=6.7 \mathrm{~Hz}), 3.18-3.25(2 \mathrm{H}, \mathrm{m}), 3.71-3.84(2 \mathrm{H}$, $\mathrm{m}) ;{ }^{13} \mathrm{C} \mathrm{NMR}\left(125.8 \mathrm{MHz}, \mathrm{CDCl}_{3}\right) \delta 1.7,3.8,24.1,24.2,24.7,27.0,50.1,65.1,75.2,96.2$. Anal. Calcd for $\mathrm{C}_{10} \mathrm{H}_{16} \mathrm{OI}_{2}$ : C, 29.58; H, 2.97. Found: C, 29.60; H, 3.73.

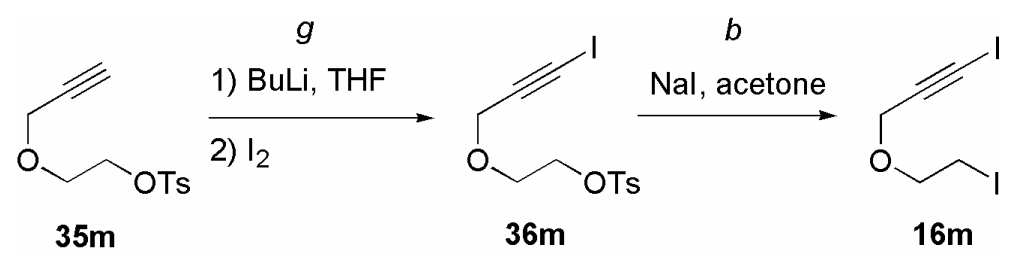

2-(3-Iodoprop-2-ynyloxy)ethyl p-Toluenesulfonate (36m). This compound was prepared from 35m according to the procedure similar to that described above (step $g$ ). The crude product was purified by flash chromatography $\left(\mathrm{SiO}_{2}, 15 \%\right.$ ethyl acetate in hexane) to give $\mathbf{3 6 m}\left(92 \%\right.$ yield): ${ }^{1} \mathrm{H} \mathrm{NMR}(500 \mathrm{MHz}$, $\left.\mathrm{CDCl}_{3}\right) \delta 2.44(3 \mathrm{H}, \mathrm{s}), 3.68-3.74(2 \mathrm{H}, \mathrm{m}), 4.16-4.21(2 \mathrm{H}, \mathrm{m}), 4.25(2 \mathrm{H}, \mathrm{s}), 7.34(2 \mathrm{H}, \mathrm{d}, J=8.3 \mathrm{~Hz}), 7.80$ $(2 \mathrm{H}, \mathrm{d} J=8.3 \mathrm{~Hz}) ;{ }^{13} \mathrm{C}$ NMR $\left(125.8 \mathrm{MHz}, \mathrm{CDCl}_{3}\right) \delta 3.60,21.7,59.9,67.2,68.8,89.7,128.0,129.8$, $132.9,144.9$.

1-Iodo-3-(2-iodoethoxy)propyne (14m). The compound was prepared from $\mathbf{3 6 m}$ according to the procedure similar to that described above (step $b$ ). The crude product was purified by Kugelrohr 
distillation $\left(100-115{ }^{\circ} \mathrm{C} / 0.2 \mathrm{mmHg}\right)$ to give $14 \mathrm{~m}\left(68 \%\right.$ yield): ${ }^{1} \mathrm{H} \mathrm{NMR}\left(500 \mathrm{MHz}, \mathrm{CDCl}_{3}\right) \delta 3.20(2 \mathrm{H}, \mathrm{t}$, $J=6.7 \mathrm{~Hz}), 3.73(2 \mathrm{H}, \mathrm{t}, J=6.7 \mathrm{~Hz}), 4.29(2 \mathrm{H}, \mathrm{s}) ;{ }^{13} \mathrm{C} \mathrm{NMR}\left(125.8 \mathrm{MHz}, \mathrm{CDCl}_{3}\right) \delta 2.0,3.5,59.5,70.5$, 90.0; MS (EI), $m / z$ (relative intensity) $336\left(\mathrm{M}^{+}, 43\right.$ ), 209 (47), 165 (100); HRMS (EI) calcd for $\mathrm{C}_{5} \mathrm{H}_{6} \mathrm{OI}_{2}$; 335.8508 , found; 335.8501

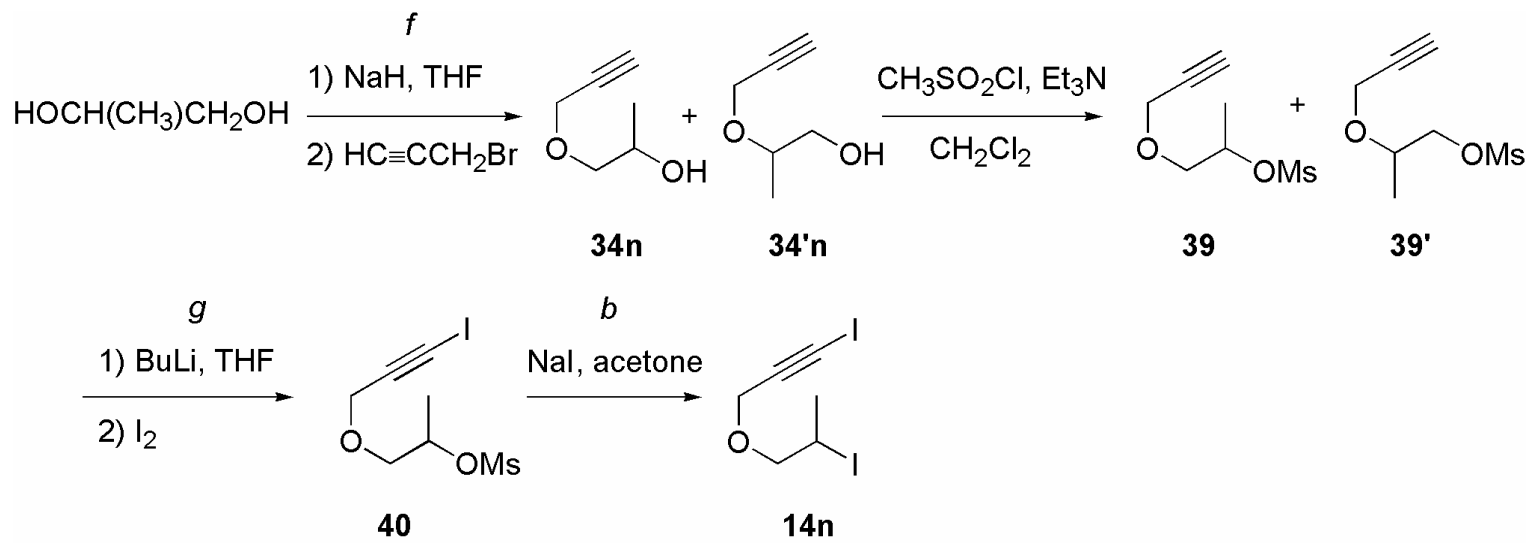

1-(prop-2-ynyloxy)propane-2-ol (34n). This compound was prepared from 1,2-propandiol according to the procedure similar to that described above (step $f$ ). The crude product was purified by flash chromatography ( $\mathrm{SiO}_{2}, 20-60 \%$ ethyl acetate in hexane) to give a inseparable mixture of $\mathbf{3 4} \mathbf{n}$ and 34n' (6:1) in 67\% yield: ${ }^{1} \mathrm{H}$ NMR (500 MHz, $\left.\mathrm{CDCl}_{3}\right) \delta 1.15$ (3H for 34n', d, $J=6.4 \mathrm{~Hz}$ ), 1.17 (3H for 34n, d, $J=6.4 \mathrm{~Hz}$ ), 2.11 (1H for 34n and 34n', br), 2.43 (1H for 34n', t, $J=2.3 \mathrm{~Hz}$ ), 2.45 (1H for 34n, t, $J=2.3 \mathrm{~Hz}$ ), 3.33 ( $1 \mathrm{H}$ for $\mathbf{3 4 n}$, dd, $J=8.1$ and $9.4 \mathrm{~Hz}$ ), 3.49 (1H for 34n', dd, $J=7.0$ and $11.6 \mathrm{~Hz}$ ), 3.55 ( $1 \mathrm{H}$ for $\mathbf{3 4 n}$, dd, $J=3.0$ and $9.4 \mathrm{~Hz}$ ), 3.62 ( $1 \mathrm{H}$ for $\mathbf{3 4 n}$ ', dd, $J=3.2$ and $11.6 \mathrm{~Hz}$ ), $3.77(1 \mathrm{H}$ for $\mathbf{3 4 n}$ ', m), 4.00 (1H for 34n, m), 4.16-4.31 (2H for 34n and 34n', m).

2-(Prop-2-ynyloxy)-1-methylethyl Methanesulfonate (39). To a solution of a 6:1 mixture of 34n and 34n' $(4.51 \mathrm{~g}, 39.5 \mathrm{mmol})$ and triethylamine $(7.3 \mathrm{~mL}, 52 \mathrm{mmol})$ in $\mathrm{CH}_{2} \mathrm{Cl}_{2}(120 \mathrm{~mL})$ at $0{ }^{\circ} \mathrm{C}$ was added methanesulfonyl chloride $(3.8 \mathrm{~mL}, 49 \mathrm{mmol})$. After being stirred for $10 \mathrm{~min}$, the reaction mixture was poured into cold water $(400 \mathrm{~mL})$ and extracted with ether $(4 \times 120 \mathrm{~mL})$. The combined organic layers were washed with $5 \%$ aq $\mathrm{NaHCO}_{3}$ and brine, dried $\left(\mathrm{MgSO}_{4}\right)$, and concentrated in vacuo. Purification of the residue by flash chromatography $\left(\mathrm{SiO}_{2}, 5 \%\right.$ ethyl acetate in toluene) gave, in the order of elution, $2.26 \mathrm{~g}$ (30\%) of 39, $2.98 \mathrm{~g}(39 \%)$ a 85:15 mixture of $\mathbf{3 9}$ and 39', and $1.49 \mathrm{~g}(20 \%)$ of a 62:38 mixture of 39 and 39'. 39: ${ }^{1} \mathrm{H} \operatorname{NMR}\left(500 \mathrm{MHz}, \mathrm{CDCl}_{3}\right) \delta 1.41(3 \mathrm{H}, \mathrm{d}, J=6.5 \mathrm{~Hz}), 2.46(1 \mathrm{H}, \mathrm{t}, J=2.3$ $\mathrm{Hz}), 3.06(3 \mathrm{H}, \mathrm{s}), 3.60-3.64(2 \mathrm{H}, \mathrm{m}), 4.20(2 \mathrm{H}, \mathrm{d}, J=2.3 \mathrm{~Hz}), 4.90(1 \mathrm{H}$, sextet, $J=6.5 \mathrm{~Hz}) ;{ }^{13} \mathrm{C} \mathrm{NMR}$ $\left(125.8 \mathrm{MHz}, \mathrm{CDCl}_{3}\right) \delta 17.9,38.4,58.4,72.2,75.1,78.3,78.8$. 39': ${ }^{1} \mathrm{H}$ NMR $\left(500 \mathrm{MHz}, \mathrm{CDCl}_{3}\right) \delta 1.24$ $(3 \mathrm{H}, \mathrm{d}, J=6.4 \mathrm{~Hz}), 2.44(1 \mathrm{H}, \mathrm{t}, J=2.3 \mathrm{~Hz}), 3.07(3 \mathrm{H}, \mathrm{s}), 3.99(1 \mathrm{H}, \mathrm{m}), 4.15-4.26(1 \mathrm{H}, \mathrm{m}) ;{ }^{13} \mathrm{C} \mathrm{NMR}$ $\left(125.8 \mathrm{MHz}, \mathrm{CDCl}_{3}\right) \delta 16.0,37.7,56.4,72.16,72.20,74.67,79.4$. 
2-(3-Iodo-prop-2-ynyloxy)-1-methylethyl Methanesulfonate (40). This compound was prepared from 39 according to the procedure similar to that described above (step $g$ ). The crude product was purified by flash chromatography $\left(\mathrm{SiO}_{2}, 3 \%\right.$ ethyl acetate in toluene) to give $\mathbf{4 0}$ (53\% yield): ${ }^{1} \mathrm{H} \mathrm{NMR}$ $\left(500 \mathrm{MHz}, \mathrm{CDCl}_{3}\right) \delta 1.41(3 \mathrm{H}, \mathrm{d}, J=6.5 \mathrm{~Hz}), 3.05(3 \mathrm{H}, \mathrm{s}), 3.57-3.64(2 \mathrm{H}, \mathrm{m}), 4.34(2 \mathrm{H}, \mathrm{m}), 4.89(1 \mathrm{H}$, sextet, $J=6.5 \mathrm{~Hz}) ;{ }^{13} \mathrm{C}$ NMR $\left(125.8 \mathrm{MHz}, \mathrm{CDCl}_{3}\right) \delta 4.0,17.9,38.4,59.9,72.2,78.2,89.7$.

1-Iodo-3-(2-iodopropoxy)propyne (14n). This compound was prepared from 40 according to the procedure similar to that described above (step $b$ ). The crude product was purified by flash chromatography $\left(\mathrm{SiO}_{2}, 5 \%\right.$ ethyl acetate in toluene) and Kugelrohr distillation $\left(75-85^{\circ} \mathrm{C} / 0.05 \mathrm{mmHg}\right.$, ) to give 14n (56\% yield): ${ }^{1} \mathrm{H}$ NMR $\left(500 \mathrm{MHz}, \mathrm{CDCl}_{3}\right) \delta 1.90(3 \mathrm{H}, \mathrm{d}, J=6.8 \mathrm{~Hz}), 3.61(1 \mathrm{H}, \mathrm{dd}, J=7.2$ and10.2 Hz), $3.73(1 \mathrm{H}, \mathrm{dd}, J=6.1$ and $10.2 \mathrm{~Hz}), 4.22(1 \mathrm{H}, \mathrm{m}), 4.35(2 \mathrm{H}, \mathrm{s}) ;{ }^{13} \mathrm{C} \mathrm{NMR}(125.8 \mathrm{MHz}$, $\left.\mathrm{CDCl}_{3}\right) \delta 3.7,23.5,24.7,59.7,76.9,90.11$; MS (EI), $m / z$ (relative intensity) $350\left(\mathrm{M}^{+}, 4\right), 223(9), 165$ (100); HRMS (EI) calcd for $\mathrm{C}_{6} \mathrm{H}_{8} \mathrm{OI}_{2} 349.8665$, found; 349.8658 .

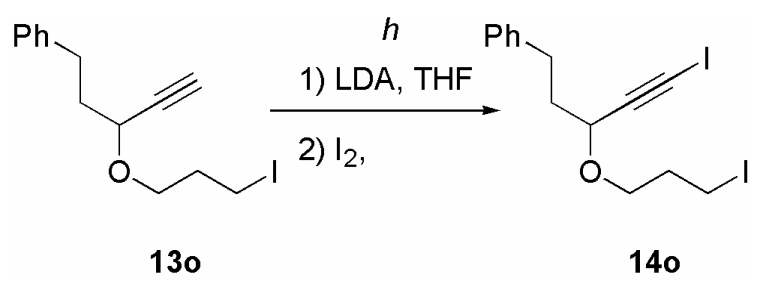

[5-Iodo-3-(3-iodopropoxy)pent-4-ynyl]benzene (140). This compound was prepared from 130 according to a procedure similar to that described above (step $h$ ). The crude product was purified by flash chromatography $\left(\mathrm{SiO}_{2}, 5 \%\right.$ ethyl acetate in hexane) to give $\mathbf{1 5 0}$ (75\% yield): ${ }^{1} \mathrm{H}$ NMR (500 MHz, $\left.\mathrm{CDCl}_{3}\right) \delta 1.96-2.14(4 \mathrm{H}, \mathrm{m}), 2.74-2.84(2 \mathrm{H}, \mathrm{m}), 3.26-3.33(2 \mathrm{H}, \mathrm{m}), 3.43(1 \mathrm{H}, \mathrm{ddd}, J=5.4,6.4$, and 9.3 $\mathrm{Hz}), 3.79(1 \mathrm{H}, \mathrm{td}, J=5.8$ and $9.3 \mathrm{~Hz}), 4.13(1 \mathrm{H}, \mathrm{t}, J=6.8 \mathrm{~Hz}) ;{ }^{13} \mathrm{C} \mathrm{NMR}\left(125.8 \mathrm{MHz}, \mathrm{CDCl}_{3}\right) \delta 2.1,3.3$, 31.3, 33.4, 37.2, 68.2, 70.4, 93.8, 126.0, 128.4, 128.5, 141.1; MS (EI), $m / z$ (relative intensity) $454\left(\mathrm{M}^{+}\right.$, 0.5), 178 (20), 141 (53), 91 (100); HRMS (EI) calcd for $\mathrm{C}_{14} \mathrm{H}_{16} \mathrm{I}_{2} \mathrm{O} 453.9251$, found; 453.9277.

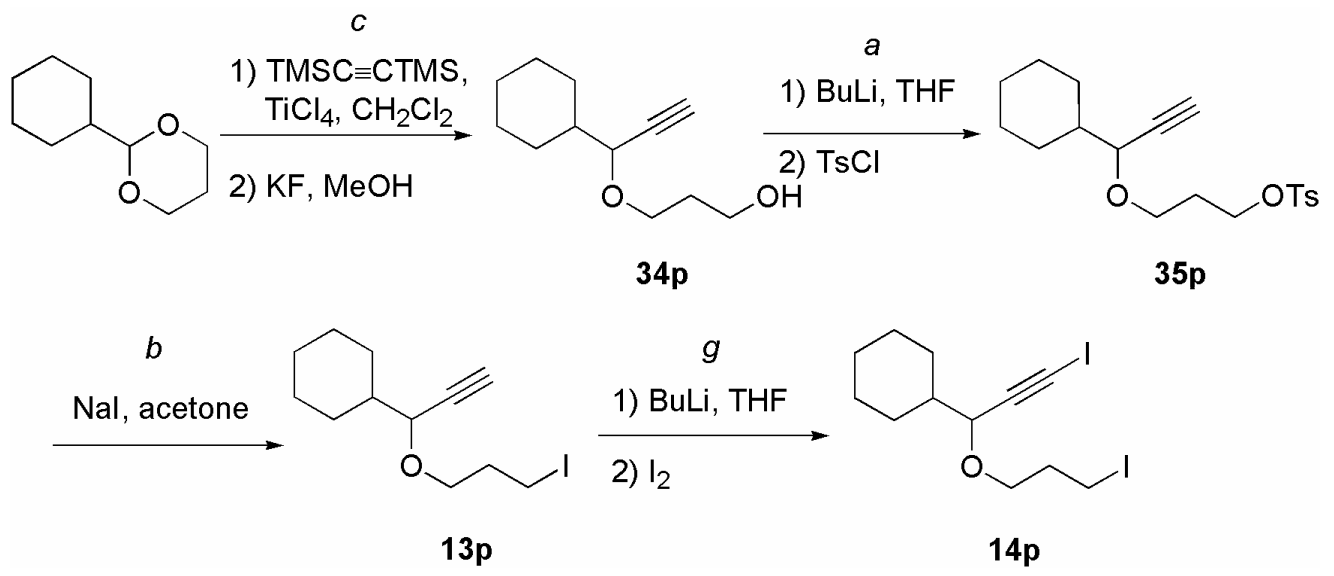


3-(1-Cyclohexylprop-2-ynyloxy)propan-1-ol (34p). This compound was prepared from 2cyclohexyl-1,3-dioxane according to a procedure similar to that described above (step $c$ ). The crude product was purified by flash chromatography $\left(\mathrm{SiO}_{2}, 20 \%\right.$ ethyl acetate in hexane) to give $\mathbf{3 4} \mathbf{p}$ (71\% yield): ${ }^{1} \mathrm{H}$ NMR $\left(500 \mathrm{MHz}, \mathrm{CDCl}_{3}\right) \delta 1.02-1.32(6 \mathrm{H}, \mathrm{m}), 1.57-1.90(7 \mathrm{H}, \mathrm{m}), 2.14(1 \mathrm{H}, \mathrm{br}), 2.43(1 \mathrm{H}, \mathrm{d}$, $J=2.1 \mathrm{~Hz}), 3.52(1 \mathrm{H}, \mathrm{m}), 3.75-3.83(3 \mathrm{H}, \mathrm{m}), 3.95(1 \mathrm{H}, \mathrm{m})$.

3-(1-Cyclohexylprop-2-ynyloxy)propyl $p$-Toluenesulfonate (35p). This compound was prepared from $34 \mathbf{p}$ according to a procedure similar to that described above (step $a$ ). The crude product was purified by flash chromatography $\left(\mathrm{SiO}_{2}, 20 \%\right.$ ethyl acetate in hexane) to give $35 \mathrm{p}$ (76\% yield): ${ }^{1} \mathrm{H}$ $\operatorname{NMR}\left(500 \mathrm{MHz}, \mathrm{CDCl}_{3}\right) \delta$ 0.90-1.31 (6H, m), $1.51(1 \mathrm{H}, \mathrm{m}), 1.62-1.78(4 \mathrm{H}, \mathrm{m}), 1.92(2 \mathrm{H}$, quint, $J=6.1$ $\mathrm{Hz}), 2.39(1 \mathrm{H}, \mathrm{d}, J=2.1 \mathrm{~Hz}), 2.45(3 \mathrm{H}, \mathrm{s}), 3.35(1 \mathrm{H}, \mathrm{td}, J=6.1$ and $9.5 \mathrm{~Hz}), 3.67(1 \mathrm{H}, \mathrm{dd}, J=2.1$ and $6.3 \mathrm{~Hz}), 3.77(1 \mathrm{H}, \mathrm{td}, J=5.7$ and $9.5 \mathrm{~Hz}), 4.07-4.17(2 \mathrm{H}, \mathrm{m}), 7.34(2 \mathrm{H}, \mathrm{d}, J=8.2 \mathrm{~Hz}), 7.79(2 \mathrm{H}, \mathrm{d}, J=$ $8.2 \mathrm{~Hz})$.

[1-(3-Iodopropoxy)prop-2-ynyl]cyclohexane (13p). This compound was prepared from 35p according to a procedure similar to that described above (step $b$ ). The crude product was purified by flash chromatography ( $\mathrm{SiO}_{2}, 5 \%$ ethyl acetate in hexane) to give 13p (85\% yield): ${ }^{1} \mathrm{H} \mathrm{NMR} \mathrm{(500} \mathrm{MHz,}$ $\left.\mathrm{CDCl}_{3}\right) \delta 1.01-1.29(5 \mathrm{H}, \mathrm{m}), 1.62(1 \mathrm{H}, \mathrm{m}), 1.67(1 \mathrm{H}, \mathrm{m}), 1.73-1.77(2 \mathrm{H}, \mathrm{m}), 1.83-1.87(2 \mathrm{H}, \mathrm{m}), 2.02-$ $2.25(2 \mathrm{H}, \mathrm{m}), 2.43(1 \mathrm{H}, \mathrm{d}, J=2.1 \mathrm{~Hz}), 3.25-3.33(2 \mathrm{H}, \mathrm{m}), 3.41(1 \mathrm{H}, \mathrm{ddd}, J=5.1,6.9$, and $9.5 \mathrm{~Hz}), 3.77-$ $3.82(2 \mathrm{H}, \mathrm{m}) ;{ }^{13} \mathrm{C} \mathrm{NMR}\left(125.8 \mathrm{MHz}, \mathrm{CDCl}_{3}\right) \delta 3.6,25.8,25.9,26.4,28.4,28.8,33.4,42.5,68.3,74.3$, $74.6,82.1$.

[3-Iodo-1-(3-iodopropoxy)prop-2-ynyl]cyclohexane (14p). This compound was prepared from 13p according to a procedure similar to that described above (step $g$ ). The crude product was purified by flash chromatography $\left(\mathrm{SiO}_{2}, 7 \%\right.$ ethyl acetate in hexane) and Kugelrohr distillation $\left(120^{\circ} \mathrm{C} / 0.05\right.$ $\mathrm{mmHg}$ ) to give $14 p$ (53\% yield): ${ }^{1} \mathrm{H}$ NMR $\left(500 \mathrm{MHz}, \mathrm{CDCl}_{3}\right) \delta 1.01-1.29(5 \mathrm{H}, \mathrm{m}), 1.58(1 \mathrm{H}, \mathrm{m}), 1.66$ $(1 \mathrm{H}, \mathrm{m}), 1.72-1.77(2 \mathrm{H}, \mathrm{m}), 1.81-1.87(2 \mathrm{H}, \mathrm{m}), 2.00-2.12(2 \mathrm{H}, \mathrm{m}), 3.24-3.33(2 \mathrm{H}, \mathrm{m}), 3.39$ (1H, ddd, $J$ $=5.1,6.7$, and $9.5 \mathrm{~Hz}), 3.78(1 \mathrm{H}, \mathrm{td}, J=5.6$ and $9.5 \mathrm{~Hz}), 3.91(1 \mathrm{H}, \mathrm{d}, J=6.4 \mathrm{~Hz}) ;{ }^{13} \mathrm{C} \mathrm{NMR}(125.8 \mathrm{MHz}$, $\left.\mathrm{CDCl}_{3}\right) \delta 1.6,3.6,25.83,25.84,26.3,28.5,28.8,33.4,42.8,68.5,76.3,93.4$; MS (EI), $\mathrm{m} / z$ (relative intensity) $432\left(\mathrm{M}^{+}, 0.5\right), 349$ (44), 305 (17), 169 (100); HRMS (EI) calcd for $\mathrm{C}_{12} \mathrm{H}_{18} \mathrm{I}_{2} \mathrm{O} 431.9447$, found; 431.9451.

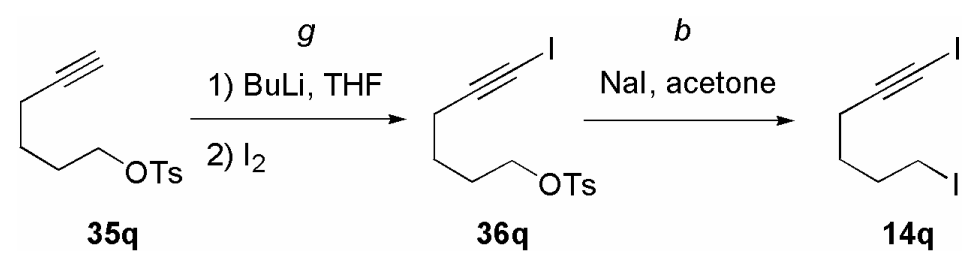

6-Iodohex-5-ynyl $\boldsymbol{p}$-Toluenesulfonate (36q). This compound was prepared from $\mathbf{3 5 q} \mathbf{q}^{6}$ according to a procedure similar to that described above (step $g$ ). The crude product was purified by flash 
chromatography $\left(\mathrm{SiO}_{2}, 10-15 \%\right.$ ethyl acetate in hexane) to give 36q (95\% yield): ${ }^{1} \mathrm{H}$ NMR (500 MHz, $\left.\mathrm{CDCl}_{3}\right) \delta 1.49-1.54(2 \mathrm{H}, \mathrm{m}), 1.70-1.76(2 \mathrm{H}, \mathrm{m}), 2.31(2 \mathrm{H}, \mathrm{t}, J=6.9 \mathrm{~Hz}), 2.44(3 \mathrm{H}, \mathrm{s}), 4.03(2 \mathrm{H}, \mathrm{t}, J=$ $6.3 \mathrm{~Hz}), 7.34(2 \mathrm{H}, \mathrm{d}, J=8.2 \mathrm{~Hz}), 7.76(2 \mathrm{H}, \mathrm{d}, J=8.2 \mathrm{~Hz}) ;{ }^{13} \mathrm{C} \mathrm{NMR}\left(125.8 \mathrm{MHz}, \mathrm{CDCl}_{3}\right) \delta-6.1,20.0$, $24.4,27.7,60.3,69.8,93.4,127.8,129.8,132.9,144.7$.

1,6-Diiodo-1-hexyne (14q). This compound was prepared from 36q according to a procedure similar to that described above $(\operatorname{step} c)$. The crude product was purified by Kugelrohr distillation (110$120{ }^{\circ} \mathrm{C} / 0.25 \mathrm{mmHg}$ ) to give $\mathbf{1 4 q}\left(76 \%\right.$ yield): ${ }^{1} \mathrm{H} \mathrm{NMR}\left(500 \mathrm{MHz}, \mathrm{CDCl}_{3}\right) \delta 1.62$ (2H, quint, $J=7.0 \mathrm{~Hz}$ ), $1.91(2 \mathrm{H}$, quint, $J=7.0 \mathrm{~Hz}), 2.40(2 \mathrm{H}, \mathrm{t}, J=7.0 \mathrm{~Hz}), 3.20(2 \mathrm{H}, \mathrm{t}, J=6.9 \mathrm{~Hz}) ;{ }^{13} \mathrm{C}$ NMR $(125.8 \mathrm{MHz}$, $\left.\mathrm{CDCl}_{3}\right) \delta-6.0,6.1,19.7,29.1,32.2$, 93.6; Anal. Calcd for $\mathrm{C}_{6} \mathrm{H}_{8} \mathrm{I}_{2}: \mathrm{C}, 21.58 ; \mathrm{H}, 2.41$. Found: $\mathrm{C}, 21.49 ; \mathrm{H}$, 2.37 .

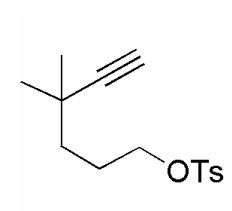

$35 r$

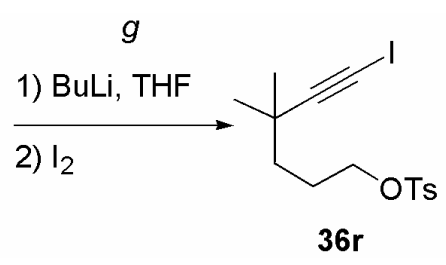

$36 r$

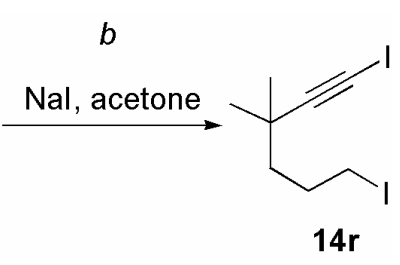

6-Iodo-4,4-dimethylhex-5-ynyl $\boldsymbol{p}$-Toluenesulfonate (36r). This compound was prepared from $\mathbf{3 5 \mathbf { r } ^ { 6 }}$ according to a procedure similar to that described above (step $g$ ). The crude product was purified by flash chromatography $\left(\mathrm{SiO}_{2}, 10-20 \%\right.$ ethyl acetate in hexane) to give 36r (70\% yield): ${ }^{1} \mathrm{H}$ NMR (500 $\left.\mathrm{MHz}, \mathrm{CDCl}_{3}\right) \delta 1.16(6 \mathrm{H}, \mathrm{s}), 1.36-1.42(2 \mathrm{H}, \mathrm{m}), 1.75-1.82(2 \mathrm{H}, \mathrm{m}), 2.45(3 \mathrm{H}, \mathrm{s}), 4.03(2 \mathrm{H}, \mathrm{t}, J=6.3$ $\mathrm{Hz}), 7.34(2 \mathrm{H}, \mathrm{d}, J=8.2 \mathrm{~Hz}), 7.76(2 \mathrm{H}, \mathrm{d}, J=.8 .2 \mathrm{~Hz}) ;{ }^{13} \mathrm{C} \mathrm{NMR}\left(125.8 \mathrm{MHz}, \mathrm{CDCl}_{3}\right) \delta-6.1,21.6,25.0$, 25.1, 28.9, 33.1, 38.9, 70.8, 100.8, 127.8, 129.8, 133.1, 144.7.

1,6-Diiodo-3,3-dimethylhex-1-yne (14r). This compound was prepared from 36r according to a procedure similar to that described above (step $b$ ). The crude product was purified by Kugelrohr distillation $\left(96{ }^{\circ} \mathrm{C} / 0.1 \mathrm{mmHg}\right)$ to give $\mathbf{1 4 r}\left(76 \%\right.$ yield): ${ }^{1} \mathrm{H}$ NMR $\left(500 \mathrm{MHz}, \mathrm{CDCl}_{3}\right) \delta 1.21(6 \mathrm{H}, \mathrm{s}), 1.47-$ $1.51(2 \mathrm{H}, \mathrm{m}), 1.93-2.00(2 \mathrm{H}, \mathrm{m}), 3.24(2 \mathrm{H}, \mathrm{t}, J=6.9 \mathrm{~Hz}) ;{ }^{13} \mathrm{C} \mathrm{NMR}\left(125.8 \mathrm{MHz}, \mathrm{CDCl}_{3}\right) \delta-6.1,7.0$, 29.1, 29.6, 33.1, 44.0, 101.2. Anal. Calcd for $\mathrm{C}_{8} \mathrm{H}_{12} \mathrm{I}_{2}: \mathrm{C}, 26.54 ; \mathrm{H}, 3.34$. Found: C, 26.32; H, 3.16.

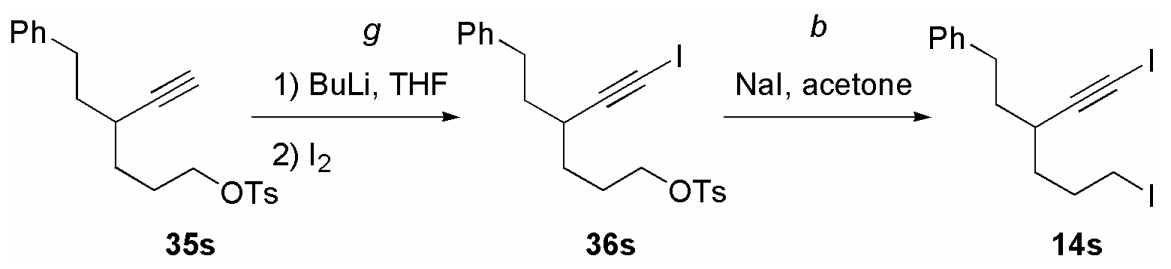

6-Iodo-4-phenethylhex-5-ynyl p-Toluenesulfonate (36s). This compound was prepared from 35s ${ }^{8}$

8 Harada, T.; Fujiwara, T.; Iwazaki, K.; Oku, A. Org. Lett. 2000, 2, 1855. 
according to a procedure similar to that described above (step $g$ ). The crude product was purified by flash chromatography $\left(\mathrm{SiO}_{2}, 10 \%\right.$ ethyl acetate in hexane) to give 36s (89\% yield): ${ }^{1} \mathrm{H}$ NMR (500 MHz, $\left.\mathrm{CDCl}_{3}\right) \delta 1.38-1.52(2 \mathrm{H}, \mathrm{m}), 1.61-1.78(3 \mathrm{H}, \mathrm{m}), 1.83(1 \mathrm{H}, \mathrm{m}), 2.49-2.48(4 \mathrm{H}, \mathrm{m}$, including $\mathrm{s}(3 \mathrm{H})$ at 2.44), $2.65(1 \mathrm{H}, \mathrm{m}), 2.79(1 \mathrm{H}, \mathrm{m}), 4.00-4.06(2 \mathrm{H}, \mathrm{m}), 7.08-7.21(3 \mathrm{H}, \mathrm{m}), 7.26-7.31(2 \mathrm{H}, \mathrm{m}), 7.34(2 \mathrm{H}, \mathrm{d}$, $J=8.2 \mathrm{~Hz}), 7.78(2 \mathrm{H}, \mathrm{d}, J=8.2 \mathrm{~Hz}) ;{ }^{13} \mathrm{C} \mathrm{NMR}\left(125.8 \mathrm{MHz}, \mathrm{CDCl}_{3}\right) \delta-4.5,21.6,26.7,30.7,32.9,33.4$, $36.6,70.2,96.7,125.9,127.9,128.38,128.41,129.8,133.1,141.5,144.7$.

1,6-Diiodo-3-(2-phenylethyl)-1-hexyne (14s). This compound was prepared from 36s according to a procedure similar to that described above (step $b$ ). The crude product was purified by flash chromatography $\left(\mathrm{SiO}_{2}, 10 \%\right.$ ethyl acetate in hexane) to give $14 \mathrm{~s}$ (81\% yield): ${ }^{1} \mathrm{H} \mathrm{NMR}$; (500 MHz, $\left.\mathrm{CDCl}_{3}\right) \delta 1.50-1.63(2 \mathrm{H}, \mathrm{m}), 1.71-1.83(2 \mathrm{H}, \mathrm{m}), 1.89(1 \mathrm{H}, \mathrm{m}), 2.03(1 \mathrm{H}, \mathrm{m}), 2.53(1 \mathrm{H}, \mathrm{tt}, J=5.1$ and 9.1 $\mathrm{Hz}), 2.70(1 \mathrm{H}, \mathrm{m}), 2.84(1 \mathrm{H}, \mathrm{m}), 3.18-3.21(2 \mathrm{H}, \mathrm{m}), 7.16-7.32(5 \mathrm{H}, \mathrm{m}) ;{ }^{13} \mathrm{C} \mathrm{NMR}\left(125.8 \mathrm{MHz}, \mathrm{CDCl}_{3}\right)$ $\delta-4.6,6.5,31.1,32.6,33.5,35.6,36.7,97.0,125.9,128.4,128.5,141.5$. Anal. Calcd for $\mathrm{C}_{14} \mathrm{H}_{16} \mathrm{I}_{2}: \mathrm{C}$, 38.38; H, 3.68. Found: C, 38.67; H, 3.98.

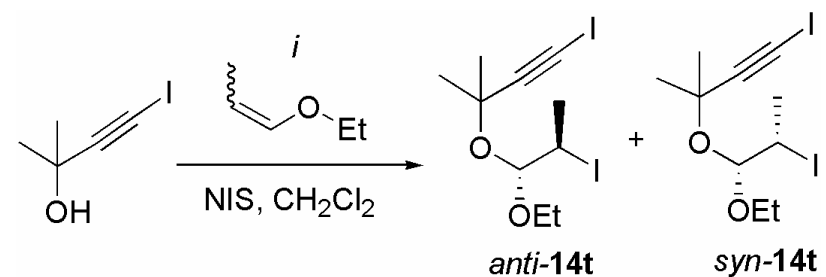

3-(1-Ethoxy-2-iodo-propoxy)-1-iodo-3-methyl-but-1-yne (14t). To a stirred suspension of 4-iodo2-methyl-but-3-yn-2-ol ${ }^{9}(2.0 \mathrm{~g}, 9.4 \mathrm{mmol})$ and $N$-iodosuccinimide $(2.4 \mathrm{~g}, 10.6 \mathrm{mmol})$ in dry $\mathrm{CH}_{2} \mathrm{Cl}_{2}(50$ $\mathrm{mL})$ at $-20^{\circ} \mathrm{C}$ was added 1-ethoxy-1-propene $(Z: E=74: 26)(2.0 \mathrm{~mL}, 17.4 \mathrm{mmol})$ over a period of $10 \mathrm{~min}$. After being stirred at $-20^{\circ} \mathrm{C}$ for $2 \mathrm{~h}$, the mixture was allowed to warm to $0{ }^{\circ} \mathrm{C}$ and stirred for $16 \mathrm{~h}$. A saturated aqueous $\mathrm{NaHCO}_{3}(50 \mathrm{~mL})$ was added, and the aqueous layer was washed with water $(2 \times 30$ $\mathrm{mL})$ and brine $(40 \mathrm{~mL})$, dried $\left(\mathrm{Na}_{2} \mathrm{SO}_{4}\right)$, and concentrated in vacuo. Purification of the residue by Kugelrohr distillation $\left(0.1 \mathrm{mmHg}, 80-100{ }^{\circ} \mathrm{C}\right)$ gave $0.728 \mathrm{~g}$ ( $86 \%$ yield) of a $25: 75$ mixture of anti- and syn-14t. A 38:62 mixture of anti- and syn-14t was obtained by a preparative recycling GPC (JAI LC-908 equipped with JAIGEL-1H and $-2 \mathrm{H}$ columns, chloroform as an eluent). 14t: ${ }^{1} \mathrm{H} \mathrm{NMR}\left(500 \mathrm{MHz}, \mathrm{C}_{6} \mathrm{D}_{6}\right)$ $\delta 1.14(3 \mathrm{H}$ for anti-14t, t, $J=7.0 \mathrm{~Hz}), 1.19(3 \mathrm{H}$ for $\operatorname{syn}-\mathbf{1 4 t}, \mathrm{t}, J=7.0 \mathrm{~Hz}), 1.32(3 \mathrm{H}$ for $\operatorname{syn} \mathbf{- 1 4 t}, \mathrm{s}), 1.39$ $(3 \mathrm{H}$ for syn-14t, s), $1.41(3 \mathrm{H}$ for anti-14t, s), $1.46(3 \mathrm{H}$ for anti-14t, s), $1.90(3 \mathrm{H}, \mathrm{d}$ for anti-14t, $J=6.9$ $\mathrm{Hz}), 1.91(3 \mathrm{H}$ for $\operatorname{syn} \mathbf{- 1 4 t}, \mathrm{d}, J=7.0 \mathrm{~Hz}), 3.34(1 \mathrm{H}$ for anti-14t, m), $3.46(1 \mathrm{H}$ for $s y n-\mathbf{1 4 t}, \mathrm{m}), 3.50(1 \mathrm{H}$ for anti-14t, m), $3.60(1 \mathrm{H}$ for syn-14t, m), $4.09(1 \mathrm{H}$ for anti-14t, dq, $J=4.7$ and $7.0 \mathrm{~Hz}), 4.20(1 \mathrm{H}$ for syn-14t, dq, $J=3.7$ and $7.0 \mathrm{~Hz}), 4.89(1 \mathrm{H}$ for anti-14t, d, $J=4.7 \mathrm{~Hz}), 5.07(1 \mathrm{H}$ for syn-14t, d, $J=3.7$ $\mathrm{Hz}) ;{ }^{13} \mathrm{C}$ NMR (125.8 MHz, $\left.\mathrm{C}_{6} \mathrm{D}_{6}\right) \delta 3.1$ (anti-14t), 3.2 (syn-14t), 15.2 (syn-14t), 15.4 (anti-14t), 20.9

9 Ricci, A.; Taddei, M.; Dembech, P.; Guerrini, A.; Seconi, G. Synthesis 1989, 461. 
(syn-14t), 22.5 (anti-14t), 27.9 (anti-14t), 28.5 (syn-14t), 29.8 (syn-14t), 30.1 (anti-14t), 30.2 (anti- and syn-14t), 61.2 (anti-14t), 62.5 (syn-14t), 72.0 (syn-14t), 72.7 (anti-14t), 96.9 (anti-14t), 97.0 (syn-14t), 101.5 (anti-14t), 101.6 (syn-14t); MS (CI) m/z (relative intensity) $423\left(\mathrm{MH}^{+}, 6\right), 377$ (70), 237 (100); HRMS (CI) calcd for $\mathrm{C}_{10} \mathrm{H}_{17} \mathrm{I}_{2} \mathrm{O}_{2}\left(\mathrm{MH}^{+}\right)$422.9318, found: 422.9313.

\section{Cycloisomerization of Iodoalkynes 13.}

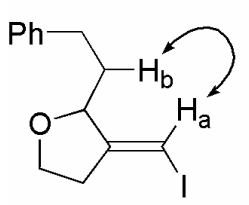

$(E)-15 a$

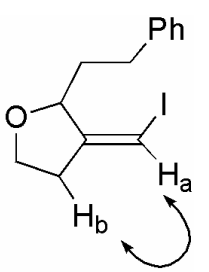

(Z)-15a

\section{3-Iodomethylene-2-phenylethyltetrahydrofuran (15a); Typical Procedure for Cycloisomerization}

of Iodoalkynes 13. To a solution of iodoalkyne 13a $(157 \mathrm{mg} .0 .5 \mathrm{mmol})$ in THF (1 mL) under argon atmosphere at $0{ }^{\circ} \mathrm{C}$ was added LDA $(1 \mathrm{M}$ solution in THF, $0.10 \mathrm{~mL}, 0.1 \mathrm{mmol})$. The resulting solution was stirred at room temperature for $5 \mathrm{~h}$. The mixture was poured into water and extracted twice with ether. The combined organic layers were dried over $\mathrm{MgSO}_{4}$ and concentrated in vacuo. The residue was purified by flash chromatography $\left(\mathrm{SiO}_{2}, 2-3 \%\right.$ ether in hexane) to afford $116 \mathrm{mg}$ ( $74 \%$ yield) of $\mathbf{1 5 a}$ $(E: Z=9.0: 1)$ as an oil. (E)-15a: ${ }^{1} \mathrm{H}$ NMR $\left(500 \mathrm{MHz}, \mathrm{CDCl}_{3}\right) \oint 1.85-2.00(2 \mathrm{H}, \mathrm{m}), 2.56-2.66(2 \mathrm{H}, \mathrm{m})$, $2.73(1 \mathrm{H}$, ddd, $J=6.9,10.0$, and $13.8 \mathrm{~Hz}), 2.82(1 \mathrm{H}$, ddd, $J=5.2,10.2$, and $13.8 \mathrm{~Hz}), 3.86(1 \mathrm{H}, \mathrm{dt}, J=$ 7.2 and $8.1 \mathrm{~Hz}), 4.11(1 \mathrm{H}, \mathrm{ddd}, J=5.1,7.1$, and $8.7 \mathrm{~Hz}), 4.29(1 \mathrm{H}, \mathrm{m}), 6.00(1 \mathrm{H}, \mathrm{q}, J=2.7 \mathrm{~Hz}), 7.20$ $7.36(5 \mathrm{H}, \mathrm{m})$; NOESY experiment showed a cross peak between $\mathrm{H}_{\mathrm{a}}(\delta 6.00)$ and $\mathrm{H}_{\mathrm{b}}(\delta 1.9) .{ }^{13} \mathrm{C} \mathrm{NMR}$ $(125.8 \mathrm{MHz}) \delta 31.5,36.1,38.3,65.6,68.4,80.6,125.9,128.35,128.38,141.6,155.5$. (Z)-15a: ${ }^{1} \mathrm{H}$ NMR (500 MHz, $\left.\mathrm{CDCl}_{3}\right) \oint 1.91(1 \mathrm{H}, \mathrm{m}), 2.15(1 \mathrm{H}, \mathrm{m}), 2.65(2 \mathrm{H}, \mathrm{m}), 2.70-2.82(2 \mathrm{H}, \mathrm{m}), 3.87(1 \mathrm{H}, \mathrm{q}, J$ $=7.4 \mathrm{~Hz}), 4.12(1 \mathrm{H}, \mathrm{m}), 4.35(1 \mathrm{H}, \mathrm{br} \mathrm{d}, J=8.7 \mathrm{~Hz}) 6.06(1 \mathrm{H}, \mathrm{q}, J=1.7 \mathrm{~Hz}), 7.17-7.30(5 \mathrm{H}, \mathrm{m})$; NOESY experiment showed a cross peak between $\mathrm{H}_{\mathrm{a}}\left(\delta\right.$ 6.06) and $\mathrm{H}_{\mathrm{b}}(\delta .2 .65) .{ }^{13} \mathrm{C} \mathrm{NMR}(125.8 \mathrm{MHz}) \delta 31.5$, 33.8, 36.1, 67.3, 67.5, 82.7, 125.8, 128.3, 128.5, 141.8, 153.3. (E)- and (Z)-15a: IR (liquid film) 3050, $1640,1250,740,700 \mathrm{~cm}^{-1}$. Anal. Calcd for $\mathrm{C}_{13} \mathrm{H}_{15} \mathrm{IO}: \mathrm{C}, 49.70 ; \mathrm{H}, 4.81$. Found: $\mathrm{C}, 49.78 ; \mathrm{H}, 4.82$.

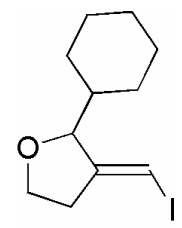


2-Cyclohexyl-3-iodomethylenetetrahydrofuran (15b): ${ }^{1} \mathrm{H}$ NMR $\left(500 \mathrm{MHz}, \mathrm{CDCl}_{3}\right) \delta$ 1.05-1.30 $(5 \mathrm{H}, \mathrm{m}), 1.52(1 \mathrm{H}, \mathrm{m}), 1.63-1.83(4 \mathrm{H}, \mathrm{m}), 2.51(1 \mathrm{H}, \mathrm{m}), 2.62(1 \mathrm{H}, \mathrm{m}), 3.84(1 \mathrm{H}, \mathrm{dt}, J=7.2$ and $8.4 \mathrm{~Hz})$, $4.07(1 \mathrm{H}, \mathrm{dt}, J=4.2$ and $8.4 \mathrm{~Hz}), 4.14(1 \mathrm{H}, \mathrm{m}), 5.97(1 \mathrm{H}, \mathrm{m}),($ minor $Z$ isomer resonated at $6.11(1 \mathrm{H}$, $\mathrm{m})$ ); ${ }^{13} \mathrm{C}$ NMR $\left(125.8 \mathrm{MHz}, \mathrm{CDCl}_{3}\right) \delta 26.2,26.3,26.4,26.5,29.7,38.7,42.2,66.0,68.3,85.8,154.4$; IR (liquid film) 3050, 1640, $1250 \mathrm{~cm}^{-1}$; MS (EI) $\mathrm{m} / z$ (relative intensity) $292\left(\mathrm{M}^{+}, 2\right), 209$ (100), 165 (53); HRMS calcd for $\mathrm{C}_{11} \mathrm{H}_{17} \mathrm{IO} 292.0324$, found: 292.0309; Anal. Calcd for $\mathrm{C}_{11} \mathrm{H}_{17} \mathrm{IO}$ : C, 45.22; H, 5.86. Found: $\mathrm{C}, 44.98 ; \mathrm{H}, 5.76$. The $E$ stereochemistry of the major isomer was assumed by analogy.

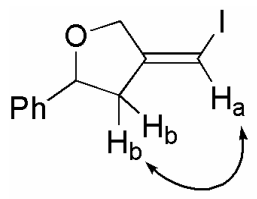

(Z)-15c

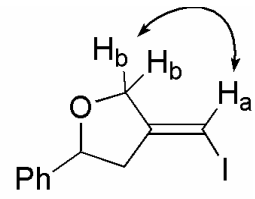

$(E)-\mathbf{1 5 c}$

4-Iodomethylene-1-oxa-2-phenylcyclopentane (15c). (Z)-15c: ${ }^{1} \mathrm{H}$ NMR $\left(500 \mathrm{MHz}, \mathrm{CDCl}_{3}\right) \delta 2.58$ $(1 \mathrm{H}$, br dd, $J=9.2$ and $15.7 \mathrm{~Hz}), 2.99(1 \mathrm{H}$, br dd, $J=5.9$ and $15.7 \mathrm{~Hz}), 3.95(1 \mathrm{H}, \mathrm{dd}, J=2.4$ and 15.9 $\mathrm{Hz}), 4.21(1 \mathrm{H}, \mathrm{dd}, J=2,4$ and $15.9 \mathrm{~Hz}), 5.08(1 \mathrm{H}, \mathrm{dd}, J=5.9$ and $9.2 \mathrm{~Hz}), 6.03(1 \mathrm{H}, \mathrm{br}$ ) $)$ 7.26-7.39 $(5 \mathrm{H}, \mathrm{m})$; NOESY experiment showed a cross peaks between $\mathrm{H}_{\mathrm{a}}(\delta 6.03)$ and $\mathrm{H}_{\mathrm{b}}(\delta 2.58$ and 2.99$) .{ }^{13} \mathrm{C}$ NMR $\left(125.8 \mathrm{MHz}, \mathrm{CDCl}_{3}\right) \delta 43.2,66.9,75.6,82.4,125.8,127.9,128.5,140.8,151.2$. (E)-15c: ${ }^{1} \mathrm{H}$ NMR $\left(500 \mathrm{MHz}, \mathrm{CDCl}_{3}\right) \delta 2.53(1 \mathrm{H}$, br dd, $J=8.8$ and $16.9 \mathrm{~Hz}), 3.01(1 \mathrm{H}$, br dd, $J=6.4$ and $16.9 \mathrm{~Hz})$, $4.40(1 \mathrm{H}, \mathrm{br} \mathrm{d}, J=13.0 \mathrm{~Hz}), 4.59(1 \mathrm{H}, \mathrm{d}, J=13.0 \mathrm{~Hz}), 5.05(1 \mathrm{H}, \mathrm{dd}, J=6.4$ and $8.8 \mathrm{~Hz}), 6.08(1 \mathrm{H}, \mathrm{br} \mathrm{s})$, 7.26-7.39 $(5 \mathrm{H}, \mathrm{m})$; NOESY experiment showed a cross peak between $\mathrm{H}_{\mathrm{a}}(\delta 6.08)$ and $\mathrm{H}_{\mathrm{b}}(\delta 4.59$ and 5.05). ${ }^{13} \mathrm{C} \mathrm{NMR}\left(125.8 \mathrm{MHz}, \mathrm{CDCl}_{3}\right) \delta 45.6,67.4,71.6,80.3,125.9,127.9,128.5,140.9,152.2$. (Z)and $(E)-17 \mathrm{c}$ : IR (liquid film) 3050, 1645, $1260 \mathrm{~cm}^{-1}$; Anal. Calcd for $\mathrm{C}_{11} \mathrm{H}_{10} \mathrm{IO}$ : C, 46.18; $\mathrm{H}, 3.88$. Found: C, 46.46; H, 3.95 .

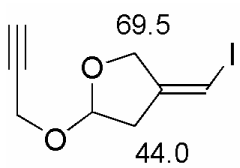

$(E)-15 d$

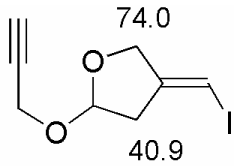

$(Z)-15 d$

4-Iodomethylene-2-(prop-2-ynyloxy)tetrahydro-furan (15d): a 1.3:1 mixture of $Z$ and $E$ isomers; ${ }^{1} \mathrm{H}$ NMR $\left(500 \mathrm{MHz}, \mathrm{CDCl}_{3}\right) \delta 2.46(1 \mathrm{H}$, br s), 2.61-2.78 $(2 \mathrm{H}, \mathrm{m}), 4.21-4.47(4 \mathrm{H}, \mathrm{m}), 5.49(1 \mathrm{H}$ for major isomer, $\mathrm{d}, J=4.5 \mathrm{~Hz}), 5.64(1 \mathrm{H}$ for minor isomer, $\mathrm{d}, J=4.5 \mathrm{~Hz}), 6.05(1 \mathrm{H}$ or minor isomer, br s), 6.11 (1H for major isomer, br s); ${ }^{13} \mathrm{C}$ NMR $\left(125.8 \mathrm{MHz}, \mathrm{CDCl}_{3}\right) \delta 40.9$ (minor isomer), 44.0 (major isomer), 53.8 (minor isomer), 54.0 (major isomer), 67.4 (minor isomer), 68.2 (major isomer), 69.5 (major isomer), 74.0 (minor isomer), 74.3 (major isomer), 74.3 (minor isomer), 79.2 (minor isomer), 
79.3 (major isomer), 101.4 (major isomer), 103.0 (minor isomer), 148.4 (minor isomer), 149.5 (major isomer). Determination of the stereochemistry was based on upfield shifts of the allylic carbons syn to the iodine atom. $^{10}$ IR (liquid film) 3275, 3060, 2120, 1640, 1245, $1085 \mathrm{~cm}^{-1}$; MS, m/z (relative intensity) 264 ( $\left.\mathrm{M}^{+}, 21\right), 225$ (10), 209 (37), 178 (100); HRMS calcd for $\mathrm{C}_{8} \mathrm{H}_{9} \mathrm{IO}_{2}$ 263.9647, found; 263.9657. Anal. Calcd for $\mathrm{C}_{8} \mathrm{H}_{9} \mathrm{IO}_{2}: \mathrm{C}, 36.39 ; \mathrm{H}, 3.44$. Found: $\mathrm{C}, 36.29 ; \mathrm{H}, 3.37$.

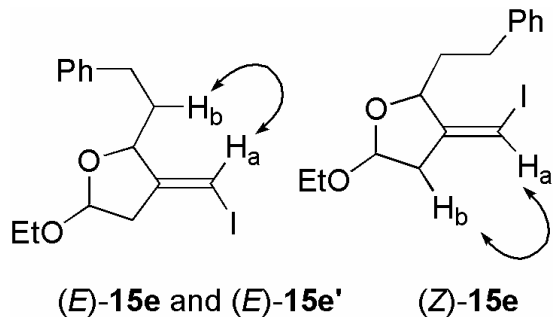

(E)-5-Ethoxy-3-iodomethylene-2-phenethyl-tetrahydrofuran (15e). (E)-15e: $R_{\mathrm{f}}=0.53$ in $10 \%$ ethyl acetate in hexane; ${ }^{1} \mathrm{H}$ NMR $\left(500 \mathrm{MHz}, \mathrm{C}_{6} \mathrm{D}_{6}\right) \delta 1.16(3 \mathrm{H}, \mathrm{t}, J=7.0 \mathrm{~Hz}), 1.73(2 \mathrm{H}, \mathrm{m}), 2.49(1 \mathrm{H}$, quitet d, $J=2.8$ and $17.3 \mathrm{~Hz}), 2.67-2.73(2 \mathrm{H}, \mathrm{m}), 2.81(1 \mathrm{H}, \mathrm{ddd}, J=2.0,10.0$, and $13.5 \mathrm{~Hz}), 3.34(1 \mathrm{H}$, qd, $J=7.0$ and $9.6 \mathrm{~Hz}), 3.79(1 \mathrm{H}, \mathrm{qd}, J=7.0$ and $9.6 \mathrm{~Hz}), 4.43(1 \mathrm{H}, \mathrm{br} \mathrm{d}, J=\mathrm{ca} .8 \mathrm{~Hz}), 5.05(1 \mathrm{H}, \mathrm{d}, J=$ $5.3 \mathrm{~Hz}), 5.62(1 \mathrm{H}, \mathrm{q}, J=2.7 \mathrm{~Hz}), 7.17(2 \mathrm{H}, \mathrm{m}), 7.25(3 \mathrm{H}, \mathrm{m})$; NOESY experiment showed a cross peak between $\mathrm{H}_{\mathrm{a}}(\delta 5.62)$ and $\mathrm{H}_{\mathrm{b}}(\delta 1.73) .{ }^{13} \mathrm{C} \mathrm{NMR}\left(125.8 \mathrm{MHz}, \mathrm{C}_{6} \mathrm{D}_{6}\right) \delta 15.1,31.5,36.4,45.1,62.4,68.9$, 78.1, 101.0, 125.7, 128.4, 128.6, 141.8, 154.0. $(E)-15 \mathbf{e}^{\prime}: R_{\mathrm{f}}=0.48$ in $10 \%$ ethyl acetate in hexane; ${ }^{1} \mathrm{H}$ $\operatorname{NMR}\left(500 \mathrm{MHz}, \mathrm{C}_{6} \mathrm{D}_{6}\right) \delta 1.29(3 \mathrm{H}, \mathrm{t}, J=7.0 \mathrm{~Hz}), 1.70(1 \mathrm{H}, \mathrm{m}), 2.04(1 \mathrm{H}, \mathrm{m}), 2.49(1 \mathrm{H}, \mathrm{br} \mathrm{d}, J=c a .17$ $\mathrm{Hz}), 2.72-2.77(2 \mathrm{H}, \mathrm{m}), 2.87(1 \mathrm{H}, \mathrm{ddd}, J=4.8,9.7$, and $14.1 \mathrm{~Hz}), 3.31(1 \mathrm{H}, \mathrm{qd}, J=7.0$ and $9.6 \mathrm{~Hz})$, $3.81(1 \mathrm{H}, \mathrm{qd}, J=7.0$ and $9.6 \mathrm{~Hz}), 4.30(1 \mathrm{H}, \mathrm{br} \mathrm{d}, J=c a .10 \mathrm{~Hz}), 5.02(1 \mathrm{H}, \mathrm{d}, J=5.6 \mathrm{~Hz}), 5.57(1 \mathrm{H}, \mathrm{q}, J$ $=2.0 \mathrm{~Hz}), 7.18(2 \mathrm{H}, \mathrm{m}), 7.25(3 \mathrm{H}, \mathrm{m})$; NOESY experiment showed a cross peak between $\mathrm{H}_{\mathrm{a}}(\delta 5.57)$ and $\mathrm{H}_{\mathrm{b}}(\delta 1.70) .{ }^{13} \mathrm{C}$ NMR $\left(125.8 \mathrm{MHz}, \mathrm{C}_{6} \mathrm{D}_{6}\right) \delta 15.0,32.4,39.4,44.8,62.7,69.1,80.7,102.2,125.7$, 128.4, 128.6, 141.8, 154.2. (Z)-15e: $R_{\mathrm{f}}=0.40$ in $10 \%$ ethyl acetate in hexane; ${ }^{1} \mathrm{H}$ NMR $(500 \mathrm{MHz}$, $\left.\mathrm{C}_{6} \mathrm{D}_{6}\right) \delta 1.16(3 \mathrm{H}, \mathrm{t}, J=7.0 \mathrm{~Hz}), 2.18(1 \mathrm{H}, \mathrm{m}), 2.38(1 \mathrm{H}, \mathrm{dddd}, J=0.5,2.0,5.7$, and $17.0 \mathrm{~Hz}), 2.43-2.52$ $(2 \mathrm{H}, \mathrm{m}), 2.92(1 \mathrm{H}$, ddd, $J=7.3,9.7$, and $13.7 \mathrm{~Hz}), 3.07(1 \mathrm{H}, \mathrm{m}), 3.35(1 \mathrm{H}, \mathrm{qd}, J=7.0$ and $9.6 \mathrm{~Hz}), 3.90$ $(1 \mathrm{H}, \mathrm{qd}, J=7.0$ and $9.6 \mathrm{~Hz}), 4.63(1 \mathrm{H}, \mathrm{br} \mathrm{d}, J=10.6 \mathrm{~Hz}), 5.08(1 \mathrm{H}, \mathrm{dd}, J=2.4$ and $5.7 \mathrm{~Hz}), 5.50(1 \mathrm{H}, \mathrm{q}$, $J=2.1 \mathrm{~Hz}), 7.17(1 \mathrm{H}, \mathrm{m}), 7.26(2 \mathrm{H}, \mathrm{m}), 7.34(2 \mathrm{H}, \mathrm{m})$; NOESY experiment showed cross peaks between $\mathrm{H}_{\mathrm{a}}(\delta 5.50)$ and $\mathrm{H}_{\mathrm{b}}\left(\delta 2.38\right.$ and 2.43-2.52). ${ }^{13} \mathrm{C} \mathrm{NMR}\left(125.8 \mathrm{MHz}, \mathrm{C}_{6} \mathrm{D}_{6}\right) \delta 15.0,32.5,35.9,41.1,63.0$, 67.2, 83.7, 104.4, 125.9, 128.4, 128.7, 141.9, 152.2. (E)-15e, 15e' and (Z)-15e: IR (liquid film) 3060, $1640,1600,1185,970,740,700 \mathrm{~cm}^{-1}$; MS, $m / z$ (relative intensity) $357\left(\mathrm{M}^{+}-1,1\right), 329$ (28), 231 (100); HRMS calcd for $\mathrm{C}_{15} \mathrm{H}_{18} \mathrm{IO}_{2}$ 357.0352, found; 357.0358 .

10 Gaudemer, A.; Gofier, M.; Mandelbaum, A.; Parthasarathy, R. Determination of Configuration by Spectrometric Methods; Kagan, H. B. Morrison, J. D., Ed.; Stereochemistry Fundamentals and Methods, vol. 1; Georg Thieme Publishers: Stuttgart, 1977; pp 55. 


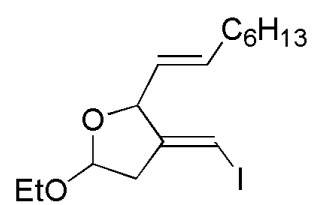

$(E)-15 f$ and $(E)-15 f^{\prime}$

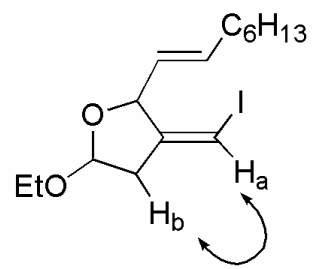

$(Z)-15 f$ and $(Z)-15 f^{\prime}$

5-Ethoxy-3-iodomethylene-2-(oct-1-enyl)tetrahydrofuran (15f). $\quad(E)-15 f$ and -15f': $R_{\mathrm{f}}=0.43$ and 0.50 in $10 \%$ ether in hexane; ${ }^{1} \mathrm{H}$ NMR $\left(500 \mathrm{MHz}, \mathrm{C}_{6} \mathrm{D}_{6}\right) \delta 0.97(3 \mathrm{H}, \mathrm{t}, J=7.2 \mathrm{~Hz}), 1.15(3 \mathrm{H}, \mathrm{t}, J=$ $7.0 \mathrm{~Hz}), 1.20-1.38(8 \mathrm{H}, \mathrm{m}), 1.96(2 \mathrm{H}, \mathrm{m}), 2.54(1 \mathrm{H}, \mathrm{m}), 2.81(1 \mathrm{H}, \mathrm{br} \mathrm{d}, J=17.0 \mathrm{~Hz}), 3.35(1 \mathrm{H}, \mathrm{qd}, J=$ 7.0 and $9.5 \mathrm{~Hz}), 3.87(1 \mathrm{H}, \mathrm{qd}, J=7.0$ and $9.5 \mathrm{~Hz}), 4.80(1 \mathrm{H}, \mathrm{br} \mathrm{d}, J=8.4 \mathrm{~Hz}), 5.05(1 \mathrm{H}, \mathrm{d}, J=5.2 \mathrm{~Hz})$, $5.51(1 \mathrm{H}, \mathrm{td}, J=6.7$ and $15.3 \mathrm{~Hz}), 5.67(1 \mathrm{H}, \mathrm{dd}, J=5.2$ and $15.2 \mathrm{~Hz}), 5.94(1 \mathrm{H}, \mathrm{m})$ for $(E)-\mathbf{1 5 f}$ and $\delta$ $0.96(3 \mathrm{H}, \mathrm{t}, J=7.2 \mathrm{~Hz}), 1.16(3 \mathrm{H}, \mathrm{t}, J=7.1 \mathrm{~Hz}), 1.20-1.42(8 \mathrm{H}, \mathrm{m}), 1.96(2 \mathrm{H}, \mathrm{m}), 2.40(1 \mathrm{H}, \mathrm{tdd}, J=2.8$, 5.4, and $17.5 \mathrm{~Hz}), 2.76(1 \mathrm{H}, \mathrm{br} \mathrm{d}, J=17.5 \mathrm{~Hz}), 3.34(1 \mathrm{H}, \mathrm{qd}, J=7.1$ and $9.6 \mathrm{~Hz}), 3.81(1 \mathrm{H}, \mathrm{qd}, J=7.1$ and $9.6 \mathrm{~Hz}), 4.95(1 \mathrm{H}$, br d, $J=7.8 \mathrm{~Hz}), 5.09(1 \mathrm{H}, \mathrm{d}, J=5.3 \mathrm{~Hz}), 5.44(1 \mathrm{H}, \mathrm{dd}, J=7.8$ and $15.3 \mathrm{~Hz})$, $5.79(1 \mathrm{H}, \mathrm{td}, J=6.7$ and $15.3 \mathrm{~Hz}), 5.96(1 \mathrm{H}, \mathrm{m})$ for $(E)-\mathbf{1 5 f} ;{ }^{13} \mathrm{C} \mathrm{NMR}\left(125.8 \mathrm{MHz}, \mathrm{C}_{6} \mathrm{D}_{6}\right) \delta 14.3,15.3$, $22.9,29.2,29.3,31.9,32.3,44.6,62.7,71.0,83.4,102.2,128.5,134.3,153.9$ for $(E)-15 f$ and $\delta 14.3$, $15.3,22.9,29.1,29.2,31.9,32.4,44.6,62.8,70.8,81.1,101.4,128.5,135.6,154.3$ for $(E)-15 f '$. Isomerization was observed between $(E)-\mathbf{1 5 f}$ and $(E)-\mathbf{1 5 f} \mathbf{f}^{\prime}$ in the attempted separation of these diastereomers by silica gel column chromatography. (Z)-15f: $R_{\mathrm{f}}=0.31$ in $10 \%$ ether in hexane; ${ }^{1} \mathrm{H}$ NMR (500 MHz, $\left.\mathrm{C}_{6} \mathrm{D}_{6}\right) \delta 0.97(3 \mathrm{H}, \mathrm{t}, J=7.2 \mathrm{~Hz}), 1.19(3 \mathrm{H}, \mathrm{t}, J=7.0 \mathrm{~Hz}), 1.24-1.38(6 \mathrm{H}, \mathrm{m}), 1.46(2 \mathrm{H}$, m), $2.12(2 \mathrm{H}, \mathrm{m}), 2.40(1 \mathrm{H}, \mathrm{ddd}, J=2.0,5.4$, and $16.8 \mathrm{~Hz}), 2.54(1 \mathrm{H}, \mathrm{br} \mathrm{d}, J=16.8 \mathrm{~Hz}), 3.35(1 \mathrm{H}, \mathrm{qd}, J$ $=7.0$ and $9.5 \mathrm{~Hz}), 3.93(1 \mathrm{H}, \mathrm{qd}, J=7.0$ and $9.5 \mathrm{~Hz}), 5.08(1 \mathrm{H}, \mathrm{d}, J=8.2 \mathrm{~Hz}), 5.11(1 \mathrm{H}$, dd, $J=2.1$ and $5.4 \mathrm{~Hz}), 5.69(1 \mathrm{H}, \mathrm{br} \mathrm{s}), 5.79(1 \mathrm{H}, \mathrm{dd}, J=8.3$ and $15.4 \mathrm{~Hz}), 5.99(1 \mathrm{H}, \mathrm{td}, J=6.8$ and $15.4 \mathrm{~Hz})$; NOESY experiment showed cross peaks between $\mathrm{H}_{\mathrm{a}}(\delta 5.99)$ and $\mathrm{H}_{\mathrm{b}}(\delta 2.40$ and 2.54$) .{ }^{13} \mathrm{C} \mathrm{NMR}(125.8 \mathrm{MHz}$, $\left.\mathrm{C}_{6} \mathrm{D}_{6}\right) \delta 14.3,15.2,22.9,29.2,29.3,32.0,32.6,41.6,62.8,69.2,85.6,104.2,128.8,136.3,151.0$. (Z)15f': $R_{\mathrm{f}}=0.36$ in $10 \%$ ether in hexane; ${ }^{1} \mathrm{H}$ NMR $\left(500 \mathrm{MHz}, \mathrm{C}_{6} \mathrm{D}_{6}\right) \delta 0.96(3 \mathrm{H}, \mathrm{t}, J=8.7 \mathrm{~Hz}), 1.12(3 \mathrm{H}, \mathrm{t}$, $J=7.0 \mathrm{~Hz}), 1.24-1.38(6 \mathrm{H}, \mathrm{m}), 1.44(2 \mathrm{H}, \mathrm{m}), 2.12(2 \mathrm{H}, \mathrm{m}), 2.40(2 \mathrm{H}, \mathrm{m}), 3.34(1 \mathrm{H}, \mathrm{qd}, J=7.0$ and 9.5 $\mathrm{Hz}), 3.81(1 \mathrm{H}, \mathrm{qd}, J=7.0$ and $9.5 \mathrm{~Hz}), 5.15(2 \mathrm{H}, \mathrm{m}), 5.63(1 \mathrm{H}, \mathrm{dd}, J=7.1$ and $15.3 \mathrm{~Hz}), 5.79(1 \mathrm{H}$, br s), $6.05(1 \mathrm{H}, \mathrm{td}, J=6.8$ and $6.9 \mathrm{~Hz})$; NOESY experiment showed a cross peak between $\mathrm{H}_{\mathrm{a}}(\delta 5.79)$ and $\mathrm{H}_{\mathrm{b}}$ (§2.40). ${ }^{13} \mathrm{C}$ NMR $\left(125.8 \mathrm{MHz}, \mathrm{C}_{6} \mathrm{D}_{6}\right) \delta 14.3,15.2,23.0,29.2,29.4,32.0,32.7,42.4,62.7,69.6,83.3$, 102.3, 126.7, 135.3, 150.6. (E)-15f, 15f' and (Z)-15f: IR (liquid film) 3060, 1640, 1195, $970 \mathrm{~cm}^{-1}$; MS, $m / z$ (relative intensity) $364\left(\mathrm{M}^{+}, 2\right), 319$ (7), 243 (95), 205 (100); HRMS calcd for $\mathrm{C}_{15} \mathrm{H}_{25} \mathrm{IO}_{2} 364.0899$, found; 364.0895 . 


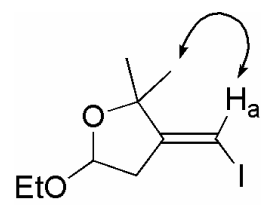

(E)-15g

(E)-5-Ethoxy-3-iodomethylene-2,2-dimethyltetrahydrofuran ((E)-15g): ${ }^{1} \mathrm{H}$ NMR $(500 \mathrm{MHz}$, $\left.\mathrm{C}_{6} \mathrm{D}_{6}\right) \delta 1.13(3 \mathrm{H}, \mathrm{t}, J=7.0 \mathrm{~Hz}), 1.20(3 \mathrm{H}, \mathrm{s}), 1.38(3 \mathrm{H}, \mathrm{s}), 2.63(1 \mathrm{H}, \mathrm{ddd}, J=3.1,5.6$, and $17.5 \mathrm{~Hz})$, $2.81(1 \mathrm{H}, \mathrm{ddd}, J=1.0,2.1$, and $17.5 \mathrm{~Hz}), 3.29(1 \mathrm{H}, \mathrm{qd}, J=7.5$ and $9.5 \mathrm{~Hz}), 3.78(1 \mathrm{H}, \mathrm{qd}, J=7.5$ and $9.5 \mathrm{~Hz}), 5.00(1 \mathrm{H}, \mathrm{d}, J=5.5 \mathrm{~Hz}), 5.71(1 \mathrm{H}, \mathrm{t}, J=2.7 \mathrm{~Hz})$; NOESY experiment showed cross peaks between $\mathrm{H}_{\mathrm{a}}(\delta 5.71)$ and $\mathrm{CH}_{3}\left(\delta 1.20\right.$ and 1.38). ${ }^{13} \mathrm{C}$ NMR $\left(125.8 \mathrm{MHz}, \mathrm{C}_{6} \mathrm{D}_{6}\right) \delta 14.9,28.9,29.8,45.0$, $62.2,68.8,83.4,100.6,159.0$; IR (liquid film) 3060, 1640, 1280, $1195 \mathrm{~cm}^{-1}$; MS, $m / z$ (relative intensity) $282\left(\mathrm{M}^{+}, 2\right), 267$ (100), 208 (38); HRMS calcd for $\mathrm{C}_{9} \mathrm{H}_{15} \mathrm{O}_{2} \mathrm{I}$ 282.0117, found; 358.0116.

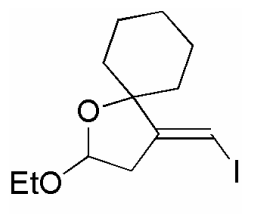

(E)-15h

(E)-2-Ethoxy-4-iodomethylene-1-oxa-spiro[4.5]decane ((E)-15h): ${ }^{1} \mathrm{H}$ NMR $\left(300 \mathrm{MHz}, \mathrm{C}_{6} \mathrm{D}_{6}\right) \delta$ $1.08(3 \mathrm{H}, \mathrm{t}, J=7.1 \mathrm{~Hz}), 1.15(1 \mathrm{H}, \mathrm{m}), 1.44-1.86(8 \mathrm{H}, \mathrm{m}), 2.07(1 \mathrm{H}, \mathrm{br} \mathrm{d}, J=c a .13 \mathrm{~Hz}), 2.62(1 \mathrm{H}, \mathrm{ddd}$, $J=3.2,5.6$ and $17.4 \mathrm{~Hz}), 2.86(1 \mathrm{H}$, ddd, $J=1.0,2.4$, and $17.4 \mathrm{~Hz}), 3.32(1 \mathrm{H}, \mathrm{qd}, J=7.1$ and $9.4 \mathrm{~Hz}$, $3.82(1 \mathrm{H}, \mathrm{qd}, J=7.1$ and $9.4 \mathrm{~Hz}), 5.03(1 \mathrm{H}, \mathrm{d}, J=5.5 \mathrm{~Hz}), 5.76(1 \mathrm{H}, \mathrm{dd}, J=2.2$ and $2.8 \mathrm{~Hz}) ;{ }^{13} \mathrm{C}$ NMR $\left(125.8 \mathrm{MHz}, \mathrm{CDCl}_{3}\right) \delta 15.1,22.4,22.6,25.3,38.4,38.6,44.9,62.4,69.1,85.4,100.5,158.7$; IR (liquid film) 3050, 1635, 1195, $980 \mathrm{~cm}^{-1}$; MS, $m / z$ (relative intensity) $322\left(\mathrm{M}^{+}, 14\right), 279$ (15), 195 (100); HRMS calcd for $\mathrm{C}_{12} \mathrm{H}_{19} \mathrm{IO}_{2}$ 322.0430, found: 322.0413. Anal. Calcd for $\mathrm{C}_{12} \mathrm{H}_{19} \mathrm{IO}_{2}$ : C, 44.74; $\mathrm{H}, 5.94$. Found: C, 44.63; H, 5.68. The $E$ stereochemistry was assumed by analogy.

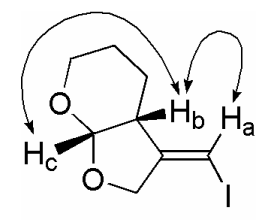

(Z)-15i

(Z)-3-Iodomethylenehexahydrofuro[2,3-b]pyran ((Z)-15i): ${ }^{1}{ }^{1} \mathrm{H}$ NMR $\left(500 \mathrm{MHz}, \mathrm{C}_{6} \mathrm{D}_{6}\right) \delta 0.78$ $(1 \mathrm{H}, \mathrm{m}), 1.25(2 \mathrm{H}, \mathrm{m}), 1.40(1 \mathrm{H}, \mathrm{m}), 2.16(1 \mathrm{H}, \mathrm{br} \mathrm{s}), 3.05(1 \mathrm{H}, \mathrm{m}), 3.66(1 \mathrm{H}, \mathrm{br} \mathrm{d}, J=$ ca. $11.5 \mathrm{~Hz}), 4.41$ $(1 \mathrm{H}$, br d, $J=$ ca. $14 \mathrm{~Hz}), 4.67(1 \mathrm{H}, \mathrm{td}, J=2.4$ and $14.3 \mathrm{~Hz}), 5.14(1 \mathrm{H}, \mathrm{d}, J=3.6 \mathrm{~Hz}), 5.53(1 \mathrm{H}, \mathrm{q}, J=$ 
$2.6 \mathrm{~Hz})$; NOESY experiment showed a cross peak between $\mathrm{H}_{\mathrm{a}}(\delta 5.53)$ and $\mathrm{H}_{\mathrm{b}}(\delta 2.16)$ and between $\mathrm{H}_{\mathrm{b}}$ $(\delta 2.16)$ and $\mathrm{H}_{\mathrm{c}}(\delta 5.14) .{ }^{13} \mathrm{C} \mathrm{NMR}\left(125.8 \mathrm{MHz}, \mathrm{C}_{6} \mathrm{D}_{6}\right) \delta 20.4,22.4,45.0,63.6,66.8,75.1,102.2,151.4$.

\section{Deuterium Scrambling Experiment.}

1-Deuterio-3-(2-iodoethoxy)-5-phenyl-1-pentyne (13a-d). To a solution of tosylate 34a (1.43 g, 4.0 mmol) in THF $(8 \mathrm{~mL})$ at $-78{ }^{\circ} \mathrm{C}$ was added butyllithium (1.6 M in hexane) $(2.6 \mathrm{~mL}, 4.2 \mathrm{mmol})$. The mixture was stirred for $2 \mathrm{~h}$ at $-78^{\circ} \mathrm{C}$ and quenched by the addition of $\mathrm{D}_{2} \mathrm{O}(1 \mathrm{~mL})$ in THF $(4 \mathrm{~mL})$. The mixture was extracted twice with ether. The organic layers were dried $\left(\mathrm{MgSO}_{4}\right)$ and concentrated in vacuo. The residue was purified by flash chromatography $\left(\mathrm{SiO}_{2}, 30 \%\right.$ ethyl acetate in hexane) to give $1.33 \mathrm{~g}$ (93\% yield) of the 1-deuterio tosylate: ${ }^{1} \mathrm{H}$ NMR $\left(300 \mathrm{MHz}, \mathrm{CDCl}_{3}\right) \delta 1.90-2.05(2 \mathrm{H}, \mathrm{m}), 2.41$ $(3 \mathrm{H}, \mathrm{s}), 2.45(0.02 \mathrm{H}, \mathrm{s}), 2.71(2 \mathrm{H}, \mathrm{t}, J=7.4 \mathrm{~Hz}), 3.55-3.61(1 \mathrm{H}, \mathrm{m}), 3.87-3.99(2 \mathrm{H}, \mathrm{m}), 4.18-4.22(2 \mathrm{H}$, m), 7.15-7.36 (7H, m), $7.81(2 \mathrm{H}, \mathrm{d}, J=8.3 \mathrm{~Hz})$.

Iodination of the 1-deuterio tosylate was carried out according to a procedure similar to that described above (step $b)$. The crude product was purified by flash chromatography $\left(\mathrm{SiO}_{2}, 3-5 \%\right.$ ethyl acetate in hexane) to give 13a-d $(98 \%-d)\left(97 \%\right.$ yield): ${ }^{1} \mathrm{H}$ NMR $\left(300 \mathrm{MHz}, \mathrm{CDCl}_{3}\right) \delta 1.98-2.16(2 \mathrm{H}, \mathrm{m}), 2.48$ $(0.02 \mathrm{H}, \mathrm{d}, J=3.49 \mathrm{~Hz}), 2.82(2 \mathrm{H}, \mathrm{t}, J=7.5 \mathrm{~Hz}), 3.26-3.30(2 \mathrm{H}, \mathrm{m}), 3.68(1 \mathrm{H}, \mathrm{td}, J=6.9$ and $10.4 \mathrm{~Hz})$, $3.95-4.08(2 \mathrm{H}, \mathrm{m}), 7.20-7.29(5 \mathrm{H}, \mathrm{m})$.

Cycloisomerization of 13a- $\boldsymbol{d}$. To a solution of 13a-d $(185 \mathrm{mg} .0 .61 \mathrm{mmol})$ and $\mathbf{1 3 b}(177 \mathrm{mg}, 0.62$ $\mathrm{mmol})$ in THF $(2.4 \mathrm{~mL})$ at $0{ }^{\circ} \mathrm{C}$ was added LDA ( $1 \mathrm{M}$ solution in THF, $\left.0.24 \mathrm{~mL}, 0.24 \mathrm{mmol}\right)$. The resulting solution was stirred at room temperature for $5 \mathrm{~h}$. The mixture was poured into water and extracted twice with ether. The combined organic layers were dried over $\mathrm{MgSO}_{4}$ and concentrated in vacuo. The residue was purified by flash chromatography $\left(\mathrm{SiO}_{2}, 2-3 \%\right.$ ether in hexane) to give 203 $\mathrm{mg}$ of a 1.1:1 mixture of $(E)-\mathbf{1 5 b}-\boldsymbol{d}(51 \%-d, 58 \%$ yield) and $(E)-\mathbf{1 5 a}-\boldsymbol{d}(48 \%-d, 52 \%$ yield $)$ and $26.4 \mathrm{mg}$ of $(E)-\mathbf{1 5 a}-\boldsymbol{d}$ (13\% yield).

\section{Cycloisomerization of Diiodoalkynes 14.}

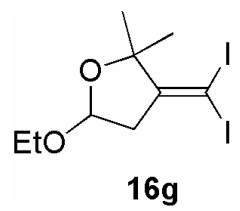

5-Ethoxy-3-diiodomethylene-2,2-dimethyltetrahydrofuran (16g); Typical Procedure for Cycloisomerization of Diiodoalkynes 14. To a solution of 1-hexyne (23 $\mu \mathrm{L}, 0.20 \mathrm{mmol})$ in THF (2 $\mathrm{mL}$ ) under argon atmosphere at $0{ }^{\circ} \mathrm{C}$ was added $\mathrm{BuLi}(1.6 \mathrm{M}$ solution in hexane) $(0.14 \mathrm{~mL}, 0.22 \mathrm{mmol})$. The resulting solution was stirred at $0{ }^{\circ} \mathrm{C}$ for $30 \mathrm{~min}$. To the resulting solution of 1-hexynyllithium in 
THF was added diiodoalkyne $\mathbf{1 4 g}(0.408 \mathrm{~g}, 1.00 \mathrm{mmol})$. The resulting solution was stirred at $40{ }^{\circ} \mathrm{C}$ for $4 \mathrm{~h}$. The mixture was poured into water and extracted three times with ethyl acetate. The combined organic layers were dried $\left(\mathrm{MgSO}_{4}\right)$ and concentrated in vacuo. The residue was purified by flash chromatography ( $\mathrm{SiO}_{2}, 2-5 \%$ ethyl acetate in hexane) to give $0.346 \mathrm{~g}$ (85\% yield) of $\mathbf{1 6 g}$ : ${ }^{1} \mathrm{H}$ NMR (500 $\left.\mathrm{MHz}, \mathrm{C}_{6} \mathrm{D}_{6}\right) \delta 1.11(3 \mathrm{H}, \mathrm{t}, J=7.0 \mathrm{~Hz}), 1.54(1 \mathrm{H}, \mathrm{s}), 1.71(1 \mathrm{H}, \mathrm{s}), 2.62(1 \mathrm{H}, \mathrm{dd}, J=5.5$, and $17.4 \mathrm{~Hz})$, $2.88(1 \mathrm{H}, \mathrm{d}, J=17.4 \mathrm{~Hz}), 3.24(1 \mathrm{H}, \mathrm{qd}, J=7.1$ and $9.4 \mathrm{~Hz}), 3.75(1 \mathrm{H}, \mathrm{qd}, J=7.1$ and $9.4 \mathrm{~Hz}), 4.76(1 \mathrm{H}$, d, $J=5.4 \mathrm{~Hz}) ;{ }^{13} \mathrm{C}$ NMR $\left(125.8 \mathrm{MHz}, \mathrm{C}_{6} \mathrm{D}_{6}\right) \delta-2.6,15.2,26.7,27.0,52.5,62.4,85.2,99.0,161.3$. Anal. Calcd for $\mathrm{C}_{9} \mathrm{H}_{14} \mathrm{O}_{2} \mathrm{I}_{2}$ : C, 26.49; H, 3.46. Found: C, 26.53; H, 3.59.

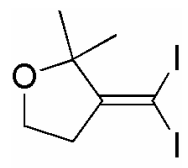

16j

3-Diiodomethylene-2,2-dimethyltetrahydrofuran (16j): ${ }^{1} \mathrm{H}$ NMR $\left(500 \mathrm{MHz}, \mathrm{CDCl}_{3}\right) \delta 1.47(6 \mathrm{H}$, s), $2.75(2 \mathrm{H}, \mathrm{t}, J=8.3 \mathrm{~Hz}), 3.81(2 \mathrm{H}, \mathrm{t}, J=8.3 \mathrm{~Hz}) ;{ }^{13} \mathrm{C} \mathrm{NMR}\left(125.8 \mathrm{MHz}, \mathrm{CDCl}_{3}\right) \delta-3.6,24.2,45.9$, 61.8, 84.3, 162.4. Anal. Calcd for $\mathrm{C}_{7} \mathrm{H}_{10} \mathrm{OI}_{2}: \mathrm{C}, 23.10 ; \mathrm{H}, 2.77$. Found: $\mathrm{C}, 23.09 ; \mathrm{H}, 2.87$.

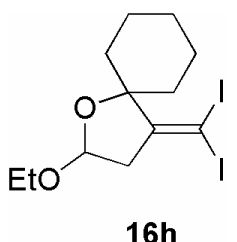

4-Diiodomethylene-2-ethoxy-1-oxaspiro[4.5]decane (16h): ${ }^{1} \mathrm{H}$ NMR $\left(500 \mathrm{MHz}, \mathrm{C}_{6} \mathrm{D}_{6}\right) \delta 1.11(3 \mathrm{H}, \mathrm{t}$, $J=7.1 \mathrm{~Hz}), 1.31(1 \mathrm{H}, \mathrm{m}), 1.52(1 \mathrm{H}, \mathrm{br} \mathrm{d}, J=c a .13 \mathrm{~Hz}), 1.68(3 \mathrm{H}, \mathrm{m}), 1.82-2.01(3 \mathrm{H}, \mathrm{m}), 2.41-2.52$ $(2 \mathrm{H}, \mathrm{m}), 2.64(1 \mathrm{H}, \mathrm{dd}, J=5.4$ and $17.2 \mathrm{~Hz}), 2.91(1 \mathrm{H}, \mathrm{d}, J=17.2 \mathrm{~Hz}), 3.27(1 \mathrm{H}, \mathrm{m}), 3.76(1 \mathrm{H}, \mathrm{m}), 4.77$ $(1 \mathrm{H}, \mathrm{d}, J=5.4 \mathrm{~Hz}) ;{ }^{13} \mathrm{C} \mathrm{NMR}\left(125.8 \mathrm{MHz}, \mathrm{C}_{6} \mathrm{D}_{6}\right) \delta-2.7,14.9,22.3,22.6,25.2,33.4,34.0,52.7,62.2$, 86.6, 98.7, 159.7. Anal. Calcd for $\mathrm{C}_{10} \mathrm{H}_{14} \mathrm{OI}_{2}$ : C, 29.73; H, 3.49. Found: C, 29.76; H, 3.46.

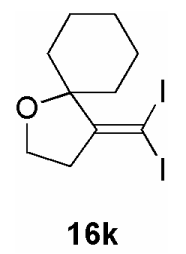

4-Diiodomethylene-1-oxaspiro[4.5]decane (16k): ${ }^{1} \mathrm{H}$ NMR $\left(500 \mathrm{MHz}, \mathrm{CDCl}_{3}\right) \delta 0.89(1 \mathrm{H}, \mathrm{m}), 1.22$ $(2 \mathrm{H}, \mathrm{m}), 1.50-1.70(5 \mathrm{H}, \mathrm{m}), 2.24(2 \mathrm{H}, \mathrm{m}), 2.73(2 \mathrm{H}, \mathrm{t}, J=6.9 \mathrm{~Hz}), 3.76(2 \mathrm{H}, \mathrm{t}, J=6.9 \mathrm{~Hz}) ;{ }^{13} \mathrm{C} \mathrm{NMR}$ 
$\left(125.8 \mathrm{MHz}, \mathrm{CDCl}_{3}\right) \delta-3.8,21.9,24.9,30.8,46.6,61.8,85,8,161.3$. Anal. Calcd for $\mathrm{C}_{10} \mathrm{H}_{14} \mathrm{OI}_{2}: \mathrm{C}$, 29.73; H, 3.49. Found: C, 29.76; H, 3.46.

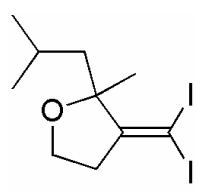

161

3-Diiodomethylene-2-isobutyl-2-methyl-tetrahydrofuran (161): ${ }^{1} \mathrm{H} \mathrm{NMR}\left(500 \mathrm{MHz}, \mathrm{CDCl}_{3}\right) \delta 0.93$ $(3 \mathrm{H}, \mathrm{d}, J=6.5 \mathrm{~Hz}), 0.94(3 \mathrm{H}, \mathrm{d}, J=6.5 \mathrm{~Hz}), 1.39(3 \mathrm{H}, \mathrm{s}), 1.51(1 \mathrm{H}, \mathrm{dd}, J=6.7$ and $14.8 \mathrm{~Hz}), 1.74(1 \mathrm{H}$, sept, $J=6.5 \mathrm{~Hz}), 2.01(1 \mathrm{H}, \mathrm{dd}, J=5.5$ and $14.8 \mathrm{~Hz}), 2.65-2.79(2 \mathrm{H}, \mathrm{m}), 3.76(1 \mathrm{H}, \mathrm{dt}, J=7.0$ and 8.6 $\mathrm{Hz}), 3.82(1 \mathrm{H}, \mathrm{dt}, J=4.6$ and $8.1 \mathrm{~Hz}) ;{ }^{13} \mathrm{C} \mathrm{NMR}\left(125.8 \mathrm{MHz}, \mathrm{CDCl}_{3}\right) \delta 3.1,23.0,23.9,24.3,24.6,44.8$, 46.6, 61.6, 87.1, 161.8. Anal. Calcd for $\mathrm{C}_{10} \mathrm{H}_{16} \mathrm{OI}_{2}$ : C, 29.58; H, 3.97. Found: C, 29.75; H, 3.70.

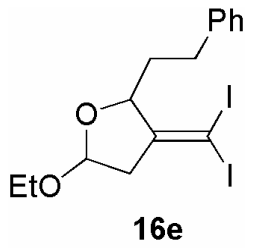

5-Ethoxy-3-diiodomethylene-2-(2-phenylethyl)tetrahydrofuran (16e): ${ }^{1} \mathrm{H}$ NMR (300 MHz, $\left.\mathrm{C}_{6} \mathrm{D}_{6}\right)$ $\delta 1.13$ ( $3 \mathrm{H}$ for major isomer, $\mathrm{t}, J=7.1 \mathrm{~Hz}$ ), 1.15 (3H for minor isomer, $\mathrm{t}, J=7.1 \mathrm{~Hz}$ ), 1.94 (1H for major isomer, $\mathrm{m}), 2.12(1 \mathrm{H}$ for minor isomer, $\mathrm{m}), 2.23-2.35(2 \mathrm{H}, \mathrm{m}), 2.39(1 \mathrm{H}$ for major isomer, ddd, $J=2.0$, 5.1 , and $16.2 \mathrm{~Hz}), 2.46(1 \mathrm{H}$ for minor isomer, dd, $J=5.9$ and $18.2 \mathrm{~Hz}), 2.59(1 \mathrm{H}$ for minor isomer, td, $J$ $=1.7$ and $18.2 \mathrm{~Hz}), 2.74(1 \mathrm{H}, \mathrm{d}, J=16.2 \mathrm{~Hz}), 2.77-2.88(2 \mathrm{H}$ for major isomer and $1 \mathrm{H}$ for minor isomer, $\mathrm{m}), 3.00(1 \mathrm{H}$ for minor isomer, $\mathrm{m}), 3.26-3.35(1 \mathrm{H}, \mathrm{m}), 3.73-3.87(1 \mathrm{H}, \mathrm{m}), 4.45(1 \mathrm{H}$ for minor isomer, br $\mathrm{d}, J=11.0 \mathrm{~Hz}$ ), $4.59(1 \mathrm{H}$ for major isomer, br d, $J=8.1 \mathrm{~Hz}), 5.05(1 \mathrm{H}$ for minor isomer, dd, $J=1.9$ and $5.8 \mathrm{~Hz}), 5.10(1 \mathrm{H}$ for major isomer, $\mathrm{d}, J=5.0 \mathrm{~Hz}), 7.16-7.31(5 \mathrm{H}, \mathrm{m}) ;{ }^{13} \mathrm{C} \mathrm{NMR}\left(125.8 \mathrm{MHz}, \mathrm{C}_{6} \mathrm{D}_{6}\right) \delta$ 0.3 (major and minor), 15.2 (major and minor), 31.5 (major), 32.6 (minor), 35.2 (major), 35.9 (minor), 48.0 (minor), 49.1 (major), 62.8 (major), 63.1 (minor), 82.7 (major), 85.2 (minor), 101.1 (major), 104.1 (minor), 126.19 (minor), 126.22 (major), 128.6 (minor), 128.7 (major), 128.88 (major), 128.94 (minor), 141.8 (minor), 141.9 (major), 157.8 (major), 159.1 (minor); MS (EI), $m / z$ (relative intensity) 484 (M+1), 438 (7), 145 (100); HRMS (EI) calcd for $\mathrm{C}_{15} \mathrm{H}_{18} \mathrm{I}_{2} \mathrm{O}_{2} ; 483.9396$, found; 483.9389. 


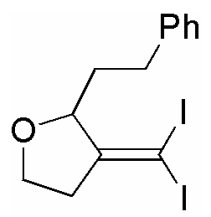

$16 a$

3-Diiodomethylene-2-(2-phenylethyl)tetrahydrofuran (16a): ${ }^{1} \mathrm{H} \mathrm{NMR}\left(500 \mathrm{MHz}, \mathrm{CDCl}_{3}\right) \delta 1.88$ $(1 \mathrm{H}, \mathrm{m}), 2.11(1 \mathrm{H}, \mathrm{m}), 2.60-2.63(2 \mathrm{H}, \mathrm{m}), 2.70(1 \mathrm{H}, \mathrm{ddd}, J=7.0,9.7$, and $13.7 \mathrm{~Hz}), 2.81(1 \mathrm{H}, \mathrm{m}), 4.06$ $(1 \mathrm{H}, \mathrm{m}), 4.16(1 \mathrm{H}, \mathrm{m}), 4.32(1 \mathrm{H}, \mathrm{br} d, J=9.5 \mathrm{~Hz}), 7.18-8.31(5 \mathrm{H}, \mathrm{m}) ;{ }^{13} \mathrm{C} \mathrm{NMR}\left(125.8 \mathrm{MHz}, \mathrm{CDCl}_{3}\right) \delta$ $-1.0,31.6,32.7,41.5,66.1,84.3,125.9,128.4,128.6,141.4,160.0$. Anal. Calcd for $\mathrm{C}_{13} \mathrm{H}_{14} \mathrm{OI}_{2}: \mathrm{C}$, 35.48; H, 3.21. Found: C, 35.29; H, 3.41 .

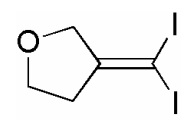

$16 \mathrm{~m}$

3-Diiodomethylenetetrahydrofuran (16m): Isolated by Kugelrohr distillation $\left(160-170{ }^{\circ} \mathrm{C} / 0.3\right.$ $\mathrm{mmHg}) ; \mathrm{mp} 62-63{ }^{\circ} \mathrm{C} ;{ }^{1} \mathrm{H} \mathrm{NMR}\left(500 \mathrm{MHz}, \mathrm{CDCl}_{3}\right) \delta 2.54(2 \mathrm{H}, \mathrm{tt}, J=1.5$ and $6.9 \mathrm{~Hz}), 4.12(2 \mathrm{H}, \mathrm{t}, J=$ $6.9 \mathrm{~Hz}), 4.17(2 \mathrm{H}, \mathrm{t}, J=1.5 \mathrm{~Hz}) ;{ }^{13} \mathrm{C} \mathrm{NMR}\left(125.8 \mathrm{MHz}, \mathrm{CDCl}_{3}\right) \delta-3.2,41.3,69.3,76.7,157.9$. Anal. Calcd for $\mathrm{C}_{5} \mathrm{H}_{6} \mathrm{OI}_{2}: \mathrm{C}, 17.88 ; \mathrm{H}, 1.80$. Found: $\mathrm{C}, 17.77 ; \mathrm{H}, 1.57$.

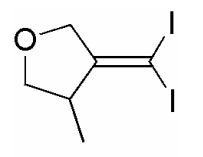

$16 n$

3-Diiodomethylene-4-methyl-tetrahydrofuran (16n): ${ }^{1} \mathrm{H}$ NMR $\left(500 \mathrm{MHz}, \mathrm{CDCl}_{3}\right) \delta 1.23(3 \mathrm{H}, \mathrm{d}$, $J=7.1 \mathrm{~Hz}), 2.78(1 \mathrm{H}, \mathrm{m}), 3.95(1 \mathrm{H}, \mathrm{br} \mathrm{d}, J=8.6 \mathrm{~Hz}), 4.01(1 \mathrm{H}, \mathrm{dd}, J=5.3$ and $8.6 \mathrm{~Hz}), 4.09(1 \mathrm{H}, \mathrm{d}, J=$ $14.6 \mathrm{~Hz}), 4.32(1 \mathrm{H}, \mathrm{dd}, J=1.3$ and $14.6 \mathrm{~Hz}) ;{ }^{13} \mathrm{C} \mathrm{NMR}\left(125.8 \mathrm{MHz}, \mathrm{CDCl}_{3}\right) \delta-3.3,16.7,46.6,76.1$, 76.8, 161.7; MS (EI), m/z (relative intensity) $350\left(\mathrm{M}^{+}, 52\right), 308$ (28), 223 (100), 128 (95); HRMS (EI) calcd for $\mathrm{C}_{6} \mathrm{H}_{8} \mathrm{OI}_{2} ; 349.8665$, found; 349.8670 .

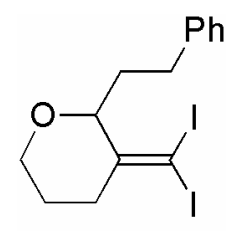

160 
3-Diiodomethylene-2-(2-phenylethyl)tetrahydropyran (16o): ${ }^{1} \mathrm{H}$ NMR $\left(500 \mathrm{MHz}, \mathrm{CDCl}_{3}\right) \delta 1.65-$ $1.82(3 \mathrm{H}, \mathrm{m}), 2.08-2.23(2 \mathrm{H}, \mathrm{m}), 2.69(1 \mathrm{H}, \mathrm{ddd}, J=2.3,6.6$, and $13.8 \mathrm{~Hz}), 2.80-2.87(2 \mathrm{H}, \mathrm{m}), 3.53(1 \mathrm{H}$, $\mathrm{td}, J=4.3$ and $11.5 \mathrm{~Hz}), 3.75(1 \mathrm{H}, \mathrm{m}), 4.58(1 \mathrm{H}, \mathrm{dd}, J=3.7$ and $10.5 \mathrm{~Hz}), 7.16-7.33(5 \mathrm{H}, \mathrm{m}) ;{ }^{13} \mathrm{C} \mathrm{NMR}$ $\left(125.8 \mathrm{MHz}, \mathrm{CDCl}_{3}\right) \delta 11.0,25.9,31.3,31.7,33.5,60.0,80.9,125.9,128.4,128.6,141.4,152.3$. Anal. Calcd for $\mathrm{C}_{14} \mathrm{H}_{16} \mathrm{OI}_{2}: \mathrm{C}, 37.03 ; \mathrm{H}, 3.55$. Found: C, 37.07; H, 3.59.

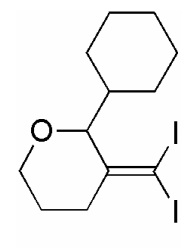

$16 p$

2-Cyclohexyl-3-diiodomethylenetetrahydropyran (16p): ${ }^{1} \mathrm{H}$ NMR $\left(500 \mathrm{MHz}, \mathrm{CDCl}_{3}\right) \delta 1.04(1 \mathrm{H}$, m), 1.12-1.24 (4H, m), $1.41(1 \mathrm{H}, \mathrm{m}), 1.63-1.84(5 \mathrm{H}, \mathrm{m}), 1.97(2 \mathrm{H}, \mathrm{m}), 2.16(1 \mathrm{H}, \mathrm{dt}, J=6.0$ and 13.7 $\mathrm{Hz}), 2.86(1 \mathrm{H}$, br d, $J=c a .15 \mathrm{~Hz}), 3.49(1 \mathrm{H}, \mathrm{m}), 3.74(1 \mathrm{H}, \mathrm{dt}, J=4.1$ and $11.2 \mathrm{~Hz}), 4.32(1 \mathrm{H}, \mathrm{d}, J=9.6$ $\mathrm{Hz}) ;{ }^{13} \mathrm{C}$ NMR $\left(125.8 \mathrm{MHz}, \mathrm{CDCl}_{3}\right) \delta 12.3,25.9,26.3,26.4,27.4,28.5,29.2,34.2,37.3,59.9,85.1$, 152.4; MS (EI), $m / z$ (relative intensity) $432\left(\mathrm{M}^{+}, 2\right), 349$ (100); HRMS (EI) calcd for $\mathrm{C}_{12} \mathrm{H}_{18} \mathrm{I}_{2} \mathrm{O}$; 431.9447, found; 431.9442 .

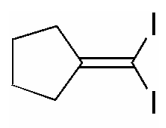

$16 q$

Diiodomethylenecyclopentane (16q): ${ }^{1} \mathrm{H}$ NMR $\left(500 \mathrm{MHz}, \mathrm{CDCl}_{3}\right) \delta 1.89(4 \mathrm{H}, \mathrm{m}), 2.29(4 \mathrm{H}, \mathrm{m}) ;{ }^{13} \mathrm{C}$ NMR $\left(125.8 \mathrm{MHz}, \mathrm{CDCl}_{3}\right) \delta$ 0.6, 27.8, 41.0, 162.7. Anal. Calcd for $\mathrm{C}_{6} \mathrm{H}_{8} \mathrm{I}_{2}: \mathrm{C}, 21.58 ; \mathrm{H}, 2.41$. Found: C, $21.31 ; \mathrm{H}, 2.31$.

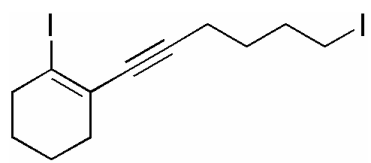

24

1-Iodo-2-(6-iodohex-1-ynyl)cyclohexene (24): ${ }^{1} \mathrm{H}$ NMR $\left(500 \mathrm{MHz}, \mathrm{CDCl}_{3}\right) \delta 1.61-1.75(6 \mathrm{H}, \mathrm{m})$, $2.03(2 \mathrm{H}$, quitet, $\mathrm{J}=7.5 \mathrm{~Hz}), 2.24-2.36(2 \mathrm{H}, \mathrm{m}), 2.39(2 \mathrm{H}, \mathrm{t}, J=6.8 \mathrm{~Hz}), 2.62-2.67(2 \mathrm{H}, \mathrm{m}), 3.23(2 \mathrm{H}, \mathrm{t}$, $J=6.9 \mathrm{~Hz}), ;{ }^{13} \mathrm{C}$ NMR $\left(125.8 \mathrm{MHz}, \mathrm{CDCl}_{3}\right) \delta 6.5,18.4,22.0,24.9,29.1,32.2,32.3,40.6,85.3,92.0$, 105.2, 128.2; MS (EI), $m / z$ (relative intensity) $414\left(\mathrm{M}^{+}, 100\right), 299$ (63), 255 (75); HRMS (EI) calcd for $\mathrm{C}_{12} \mathrm{H}_{16} \mathrm{I}_{2} 413.9341$, found; 413.9343. 


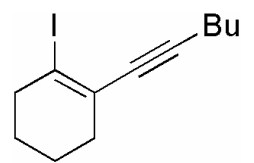

25

1-Hex-1-ynyl-2-iodocyclohexene (25): ${ }^{1} \mathrm{H}$ NMR $\left(500 \mathrm{MHz}, \mathrm{CDCl}_{3}\right) \delta 0.92(3 \mathrm{H}, \mathrm{t}, J=7.2 \mathrm{~Hz}), 1.45-$ $1.52(2 \mathrm{H}, \mathrm{m}), 1.52-1.59(2 \mathrm{H}, \mathrm{m}), 1.59-1.67(2 \mathrm{H}, \mathrm{m}), 1.67-1.73(2 \mathrm{H}, \mathrm{m}), 2.25-2.30(2 \mathrm{H}, \mathrm{m}), 2.35(2 \mathrm{H}, \mathrm{t}$, $\mathrm{J}=7.0 \mathrm{~Hz}), 2.63-2.68(2 \mathrm{H}, \mathrm{m}),{ }^{13} \mathrm{C} \mathrm{NMR}\left(125.8 \mathrm{MHz}, \mathrm{CDCl}_{3}\right) \delta 13.6,19.2,22.0,25.0,30.6,32.4,45.6$, 48.4, 84.6, 93.3, 104.7, 128.4; MS (EI), $m / z$ (relative intensity) $288\left(\mathrm{M}^{+}, 100\right), 255$ (7), 253 (6), 161 (11); HRMS (EI) calcd for $\mathrm{C}_{12} \mathrm{H}_{17} \mathrm{I} 288.0375$, found; 288.0391 .

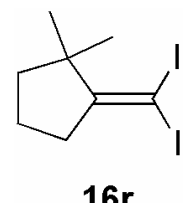

$16 r$

1-Diiodomethylene-2,2-dimethylcyclopentane (16r): ${ }^{1} \mathrm{H}$ NMR $\left(500 \mathrm{MHz}, \mathrm{CDCl}_{3}\right), 1.30(6 \mathrm{H}, \mathrm{s})$, $1.60(2 \mathrm{H}$, quint, $J=7.0 \mathrm{~Hz}), 1.86(2 \mathrm{H}, \mathrm{t}, J=6.8 \mathrm{~Hz}), 2.51(2 \mathrm{H}, \mathrm{t}, J=7.2 \mathrm{~Hz}) ;{ }^{13} \mathrm{C} \mathrm{NMR}(125.8 \mathrm{MHz}$, $\left.\mathrm{CDCl}_{3}\right) \delta-3.8,21.2,25.6,46.6,47.1,47.9,165.1$. Anal. Calcd for $\mathrm{C}_{8} \mathrm{H}_{12} \mathrm{I}_{2} \mathrm{C} 26.54, \mathrm{H}, 3.34$. Found: $\mathrm{C}$, 26.32, H, 3.16.

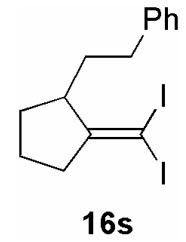

[2-(2-Diiodomethylenecyclopentyl)ethyl]benzene (16s): ${ }^{1} \mathrm{H}$ NMR $\left(500 \mathrm{MHz}, \mathrm{CDCl}_{3}\right) \delta 1.53(1 \mathrm{H}$, m), 1.85-2.02 (5H, m), $2.27(1 \mathrm{H}, \mathrm{m}), 2.39(1 \mathrm{H}, \mathrm{m}), 2.58-2.66(2 \mathrm{H}, \mathrm{m}), 2.72(1 \mathrm{H}, \mathrm{ddd}, \mathrm{J}=4.9,10.5$, and 15.1 Hz), 7.17-7.33 (5H, m); ${ }^{13} \mathrm{C}$ NMR (125.8 MHz, $\left.\mathrm{CDCl}_{3}\right) \delta 1.4,24.7,31.6,33.4,34.1,40.4,50.4$, 125.8, 128.3, 128.5, 141.8, 165.4. Anal. Calcd for $\mathrm{C}_{14} \mathrm{H}_{16} \mathrm{I}_{2}: \mathrm{C}, 38.38 ; \mathrm{H}, 3.68$. Found: $\mathrm{C}, 38.38$; $\mathrm{H}$, 3.76 . 


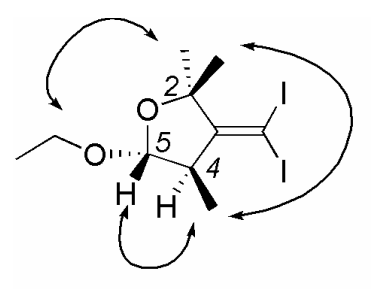

trans-16t

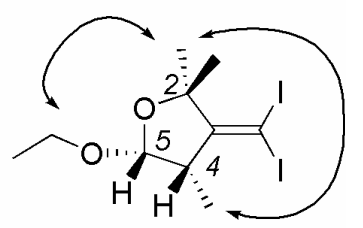

cis-16t

3-Diiodomethylene-5-ethoxy-2,2,4-trimethyl-tetrahydrofuran (16t). trans-16t: ${ }^{1} \mathrm{H}$ NMR (500 $\left.\mathrm{MHz}, \mathrm{C}_{6} \mathrm{D}_{6}\right) \delta 1.12(3 \mathrm{H}, \mathrm{d}, J=7.3 \mathrm{~Hz}), 1.12(3 \mathrm{H}, \mathrm{t}, J=7.0 \mathrm{~Hz}), 1.59(3 \mathrm{H}, \mathrm{s}), 1.79(3 \mathrm{H}, \mathrm{s}), 3.14(1 \mathrm{H}, \mathrm{q}, J$ $=7.3 \mathrm{~Hz}), 3.25(1 \mathrm{H}, \mathrm{m}), 3.77(1 \mathrm{H}, \mathrm{m}), 4.58(1 \mathrm{H}, \mathrm{s}) ;{ }^{1} \mathrm{H}$ NMR $\left(500 \mathrm{MHz}, \mathrm{CDCl}_{3}\right) \delta 1.18(3 \mathrm{H}, \mathrm{t}, J=7.1$ Hz), $1.25(3 \mathrm{H}, \mathrm{d}, J=7.3 \mathrm{~Hz}), 1.51(3 \mathrm{H}, \mathrm{s}), 1.63(3 \mathrm{H}, \mathrm{s}), 2.99(1 \mathrm{H}, \mathrm{q}, J=7.3 \mathrm{~Hz}), 3.39(1 \mathrm{H}, \mathrm{m}), 3.76(1 \mathrm{H}$, $\mathrm{m}), 4.68(1 \mathrm{H}, \mathrm{s})$; NOESY $\left(\mathrm{CDCl}_{3}\right)$ experiment showed cross peaks between $2 \beta-\mathrm{CH}_{3}(\delta 1.63)$ and $4-\mathrm{CH}_{3}$ $(\delta 1.25)$, between $4-\mathrm{CH}_{3}(\delta 1.25)$ and $5-\mathrm{H}(\delta 4.68)$, and between $2 \alpha-\mathrm{CH}_{3}(\delta 1.51)$ and $\mathrm{CH}_{3} \mathrm{CH}_{2} \mathrm{O}(\delta 3.76)$; ${ }^{13} \mathrm{C}$ NMR $\left(125.8 \mathrm{MHz}, \mathrm{C}_{6} \mathrm{D}_{6}\right) \delta-2.3,15.1,16.1,27.5,27.7,57.5,62.2,85.5,105.2,165.4$. cis-16t: ${ }^{1} \mathrm{H}$ NMR $\left(500 \mathrm{MHz}, \mathrm{C}_{6} \mathrm{D}_{6}\right) \delta 1.15(3 \mathrm{H}, \mathrm{t}, J=7.1 \mathrm{~Hz}), 1.39(3 \mathrm{H}, \mathrm{d}, J=7.1 \mathrm{~Hz}), 1.53(3 \mathrm{H}, \mathrm{s}), 1.62(3 \mathrm{H}, \mathrm{s})$, $2,95(1 \mathrm{H}, \mathrm{dq}, J=4.6$ and $7.1 \mathrm{~Hz}), 3.37(1 \mathrm{H}, \mathrm{m}), 3.83(1 \mathrm{H}, \mathrm{m}), 4.81(1 \mathrm{H}, \mathrm{d}, J=4.6 \mathrm{~Hz})$; NOESY experiment showed cross peaks between $2 \alpha-\mathrm{CH}_{3}(\delta 1.62)$ and $4-\mathrm{CH}_{3}(\delta 1.39)$ and between $2 \alpha-\mathrm{CH}_{3}(\delta$ 1.62) and $\mathrm{CH}_{3} \mathrm{CH}_{2} \mathrm{O}(\delta 3.83)$; ${ }^{13} \mathrm{C}$ NMR $\left(125.8 \mathrm{MHz}, \mathrm{C}_{6} \mathrm{D}_{6}\right) \delta-2.3,12.0,15.4,24.9,27.2,53.6,65.0$, 82.8, 100.0, 165.2. A mixture of cis- and trans-16t; Anal. Calcd for $\mathrm{C}_{10} \mathrm{H}_{16} \mathrm{O}_{2} \mathrm{I}_{2}: \mathrm{C}, 28.46 ; \mathrm{H}, 3.82$. Found: C, 28.61; H, 3.67.

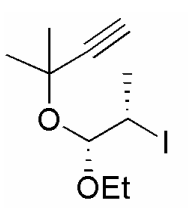

syn-13t

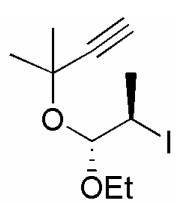

anti-13t

3-(1-Ethoxy-2-iodopropoxy)-3-methylbut-1-yne (13t): Authentic sample of this compound was prepared from 2-methylbut-3-yn-2-ol and 1-ethoxy-1-propene $(Z: E=74: 26)$ in $78 \%$ yield as a $84: 16$ mixture of the syn and anti isomer according to a procedure similar to that described above (step $i$ ). The crude product was purified by Kugelrohr distillation $\left(70-85^{\circ} \mathrm{C} / 0.5 \mathrm{mmHg}\right)$ to give $13 \mathrm{t}$ (78\% yield): ${ }^{1} \mathrm{H}$ NMR (500 MHz, $\left.\mathrm{C}_{6} \mathrm{D}_{6}\right)(\mathrm{a} 84: 16$ mixture of syn- and anti-13t) $\delta 1.14(3 \mathrm{H}$ for anti-13t, t, $J=7.1 \mathrm{~Hz})$, $1.20(1 \mathrm{H}$ for syn-13t, t, $J=7.1 \mathrm{~Hz}), 1.39(3 \mathrm{H}$ for $\operatorname{syn}-\mathbf{1 3 t}, \mathrm{s}), 1.44(3 \mathrm{H}$ for syn-13t, s), $1.47(3 \mathrm{H}$ for anti13t, s), 1.52 (3H for anti-13t, s), $1.92(3 \mathrm{H}$ for anti-13t, d, $J=7.0 \mathrm{~Hz}), 1.96(3 \mathrm{H}$ for $s y n-13 t, \mathrm{~d}, J=7.0$ $\mathrm{Hz}), 2.09(1 \mathrm{H}$ for syn-and anti-13t, br s), $3.39(1 \mathrm{H}$ for anti-13t, m), 3.48(1H for syn-13t, m), $3.56(1 \mathrm{H}$ for anti-13t, $\mathrm{m}), 3.64(1 \mathrm{H}$ for syn-13t, $\mathrm{m}), 4.15(1 \mathrm{H}$ for anti-13t, dq, $J=5.1$ and $7.0 \mathrm{~Hz}), 4.26(1 \mathrm{H}$ for syn13t, dq, $J=3.6$ and $7.0 \mathrm{~Hz}$ ), $4.97(1 \mathrm{H}$ for anti-13t, d, $J=5.1 \mathrm{~Hz}), 5.13(1 \mathrm{H}$ for $\operatorname{syn}-\mathbf{1 3 t}, \mathrm{d}, J=3.6 \mathrm{~Hz})$; ${ }^{13} \mathrm{C}$ NMR (125.8 MHz, $\mathrm{C}_{6} \mathrm{D}_{6}$ ) (a 84:16 mixture of syn- and anti-13t) $\delta 15.1$ (syn-13t), 15.3 (anti-13t), 
20.7 (syn-13t), 22.9 (anti-13t), 28.0 (anti-13t), 28.8 (syn-13t), 29.8 (syn-13t), 30.1 (anti-13t), 30.5 (syn13t), 31.4 (anti-13t), 60.6 (anti-13t), 62.6 (syn-13t), 70.2 (syn-13t), 71.0 (anti-13t), 73.6 (syn-13t), 73.8 (anti-13t), 85.8 (anti-13t), 85.9 (syn-13t), 101.4 (anti-13t), 101.5 (syn-13t).

\section{Atom Transfer-Type Cyclization of Iodoalkynes 13.}

Typical Procedure for Iodine Atom Transfer-Type Cyclization of Iodoalkynes 13; Preparation of 3Diiodomethylene-5-ethoxy-2,2-dimethyltetrahydrofuran (16g). To a solution of 1-iodo-1-hexyne11 $(0.12 \mathrm{~mL}, 0.75 \mathrm{mmol})$ in THF $(1 \mathrm{~mL})$ under argon atmosphere at $0{ }^{\circ} \mathrm{C}$ was added BuLi (1.6 M solution in hexane) $(0.13 \mathrm{~mL}, 0.20 \mathrm{mmol})$. The resulting solution was stirred at $0{ }^{\circ} \mathrm{C}$ for $30 \mathrm{~min}$. To the resulting solution of 1-hexynyllithium $(0.2 \mathrm{mmol})$ and 1-iodo-1-hexyne $(0.55 \mathrm{mmol})$ in THF was added iodoalkyne $13 \mathrm{~g}(0.141 \mathrm{~g}, 0.50 \mathrm{mmol})$. The resulting solution was stirred at $40{ }^{\circ} \mathrm{C}$ for $1.5 \mathrm{~h}$. The mixture was poured into water and extracted twice with ethyl acetate. The combined organic layers were dried $\left(\mathrm{Na}_{2} \mathrm{SO}_{4}\right)$ and concentrated in vacuo. The residue was purified by flash chromatography $\left(\mathrm{SiO}_{2}, 7 \%\right.$ ethyl acetate in hexane) to give $0.165 \mathrm{~g}(81 \%$ yield $)$ of $\mathbf{1 6 g}$.

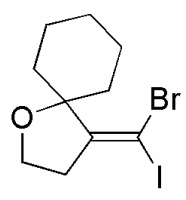

$19 k$

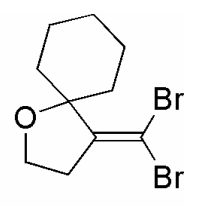

$31 \mathrm{k}$

\section{4-Bromoiodomethylene-1-oxaspiro[4.5]decane (19k) and 4-Dibromomethylene-1-} oxaspiro[4.5]decane (31k); Typical Procedure for Bromine Atom Transfer-Type Cyclization of Iodoalkynes 13. To a solution of 1-octyne $(0.030 \mathrm{~mL}, 0.20 \mathrm{mmol})$ in THF $(1 \mathrm{~mL})$ under argon atmosphere at $0{ }^{\circ} \mathrm{C}$ was added $\mathrm{BuLi}(1.6 \mathrm{M}$ solution in hexane) $(0.125 \mathrm{~mL}, 0.200 \mathrm{mmol})$. The resulting solution was stirred at $0{ }^{\circ} \mathrm{C}$ for $30 \mathrm{~min}$. To the resulting solution of 1-octynyllithium in THF was added 1-bromo-1-octyne ${ }^{12}(0.160 \mathrm{~g}, 0.846 \mathrm{mmol})$. The resulting solution was stirred at $0{ }^{\circ} \mathrm{C}$ for $30 \mathrm{~min}$. To this was then added iodoalkyne $13 \mathrm{k}(0.139 \mathrm{~g}, 0.500 \mathrm{mmol})$. The resulting solution was stirred at $0{ }^{\circ} \mathrm{C}$ for $14 \mathrm{~h}$. The mixture was poured into water and extracted three times with ethyl acetate. The combined organic layers were dried $\left(\mathrm{Na}_{2} \mathrm{SO}_{4}\right)$ and concentrated in vacuo. The residue was purified by flash chromatography $\left(\mathrm{SiO}_{2}, 4 \%\right.$ ethyl acetate in hexane) to give $0.142 \mathrm{~g}$ of a mixture of $19 \mathrm{k}$ ( $45 \%$ yield) and

11 The iodoalkyne was prepared by the reaction of 1-hexynyllithium with $\mathrm{I}_{2}$. (a) Webb, J. A.; Klijn, J. E.; Hill, P. A.; Bennet., J. L.; Goroff, N. S. J. Org. Chem. 2004, 69, 660. (b) Luithle, J. E. A; Pietruszka; J. Eur. J. Org. Chem. 2000, 2557.

12 The bromoalkyne was prepared by the reaction of 1-octyne with NIS in the presence of $\mathrm{AgNO}_{3}$. (a) Marino, J. P.; Nguyen, H. N. J. Org. Chem. 2002, 67, 6841. (b) Kabalka, G. W.; Mereddy, A. R. Organometallics 2004, 23, 4519. 
$31 \mathbf{k}$ (40\% yield). The products were isolated by a preparative recycling GPC (JAI LC-908 equipped with JAIGEL-1H and $-2 \mathrm{H}$ columns, chloroform as an eluent). 19k: ${ }^{1} \mathrm{H}$ NMR $\left(500 \mathrm{MHz}, \mathrm{CDCl}_{3}\right) \delta 1.22(1 \mathrm{H}$, m), 1.50-1.67 (8H, m), 2.16-2.25 (2H, m), $2.66(2 \mathrm{H}, \mathrm{t}, J=6.8 \mathrm{~Hz}), 3.82(2 \mathrm{H}, \mathrm{t}, J=6.8 \mathrm{~Hz}) ;{ }^{13} \mathrm{C} \mathrm{NMR}$ $\left(125.8 \mathrm{MHz}, \mathrm{CDCl}_{3}\right) \delta 22.0,25.0,30.8,39.7,45.1,62.4,85.6,157.5$; MS (EI), $\mathrm{m} / z$ (relative intensity) 358, $356\left(\mathrm{M}^{+}, 27,28\right), 315,313(100,98), 231,229$ (76, 78); HRMS (EI) calcd for $\mathrm{C}_{10} \mathrm{H}_{14} \mathrm{O}^{81} \mathrm{BrI}$ 357.9252, found; 357.9261, calcd for $\mathrm{C}_{10} \mathrm{H}_{14} \mathrm{O}^{79} \mathrm{BrI} 355.9273$, found; 355.9282 . 31k: ${ }^{1} \mathrm{H}$ NMR (500 $\left.\mathrm{MHz}, \mathrm{CDCl}_{3}\right) \delta 1.21(1 \mathrm{H}, \mathrm{m}), 1.52-1.69(8 \mathrm{H}, \mathrm{m}), 2.09-2.18(2 \mathrm{H}, \mathrm{m}), 2.71(2 \mathrm{H}, \mathrm{t}, J=6.8 \mathrm{~Hz}), 3.83(2 \mathrm{H}$, $\mathrm{t}, J=6.8 \mathrm{~Hz}) ;{ }^{13} \mathrm{C} \mathrm{NMR}\left(125.8 \mathrm{MHz}, \mathrm{CDCl}_{3}\right) \delta 22.0,25.0,30.7,40.3,62.9,78.4,85.4,151.9$; MS (EI), $m / z$ (relative intensity) 312, 310, $308\left(\mathrm{M}^{+}, 13,28,15\right), 269,267,265(54,100,52), 231,229(54,57)$; HRMS (EI) calcd for $\mathrm{C}_{10} \mathrm{H}_{14} \mathrm{O}^{81} \mathrm{Br}_{2}$ 311.9370, found; 311.9395; $\mathrm{C}_{10} \mathrm{H}_{14} \mathrm{O}^{81} \mathrm{Br}^{79} \mathrm{Br}$ 307.9411, found; 309.9399; $\mathrm{C}_{10} \mathrm{H}_{14} \mathrm{O}^{79} \mathrm{Br}_{2}$ 307.9411, found; 307.9413 .

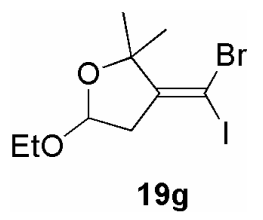

3-Bromoiodomethylene-5-ethoxy-2,2-dimethyltetrahydrofuran (19g): ${ }^{1} \mathrm{H}$ NMR (500 MHz, $\left.\mathrm{C}_{6} \mathrm{D}_{6}\right)$ $\delta 1.08(3 \mathrm{H}, \mathrm{t}, J=7.1 \mathrm{~Hz}), 1.54(3 \mathrm{H}, \mathrm{s}), 1.71(3 \mathrm{H}, \mathrm{s}), 2.58(1 \mathrm{H}, \mathrm{dd}, J=5.4$ and $17.4 \mathrm{~Hz}), 2.77(1 \mathrm{H}, \mathrm{d}, J=$ $17.4 \mathrm{~Hz}), 3.24(1 \mathrm{H}, \mathrm{qd}, J=7.1$ and $9.2 \mathrm{~Hz}), 3.75(1 \mathrm{H}, \mathrm{qd}, J=7.1$ and $9.2 \mathrm{~Hz}), 4.84(1 \mathrm{H}, J=5.4 \mathrm{~Hz}) ;{ }^{13} \mathrm{C}$ NMR $\left(125.8 \mathrm{MHz}, \mathrm{C}_{6} \mathrm{D}_{6}\right) \delta 15.1,26.2,26.9,40.3,46.5,51.1,62.3,84.9,99.7,100.3,157.0$; MS (EI), $m / z$ (relative intensity) 362, $360\left(\mathrm{M}^{+}, 9,9\right), 347,319(100,100), 288,286(57,42)$; HRMS (EI) calcd for $\mathrm{C}_{9} \mathrm{H}_{14} \mathrm{O}_{2}{ }^{81} \mathrm{BrI}$ 361.9201, found; 361.9196, calcd for $\mathrm{C}_{9} \mathrm{H}_{14} \mathrm{O}_{2}{ }^{79} \mathrm{BrI} 359.9222$, found; 359.9217.

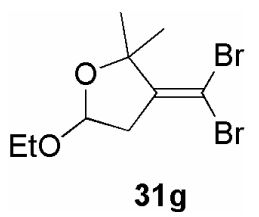

3-Dibromomethylene-5-ethoxy-2,2-dimethyltetrahydrofuran (31g): ${ }^{1} \mathrm{H} \mathrm{NMR}\left(500 \mathrm{MHz}, \mathrm{C}_{6} \mathrm{D}_{6}\right) \delta$ $1.12(3 \mathrm{H}, \mathrm{t}, J=7.1 \mathrm{~Hz}), 1.52(3 \mathrm{H}, \mathrm{s}), 1.69(3 \mathrm{H} . \mathrm{s}), 2.58(1 \mathrm{H}, \mathrm{dd}, J=5.4$ and $17.4 \mathrm{~Hz}), 2.77(1 \mathrm{H}, \mathrm{d}, J=$ $17.1 \mathrm{~Hz}), 2.84(1 \mathrm{H}, \mathrm{d}, J=17.4 \mathrm{~Hz}), 3.24(1 \mathrm{H}, \mathrm{qd}, J=7.1$ and $9.4 \mathrm{~Hz}), 3.75(1 \mathrm{H}, \mathrm{qd}, J=7.1$ and $9.4 \mathrm{~Hz})$, $4.84(1 \mathrm{H}, J=5.4 \mathrm{~Hz}) ;{ }^{13} \mathrm{C}$ NMR $\left(125.8 \mathrm{MHz}, \mathrm{C}_{6} \mathrm{D}_{6}\right) \delta$ 15.2, 26.2, 26.8, 46.6, 62.4, 79.2, 84.9, 100.4, 151.6; MS (EI), $m / z$ (relative intensity) 316, 314, $312\left(\mathrm{M}^{+}, 2,3,2\right), 301,299,297$ (49, 100, 51), 271, 269, 267 (28, 37, 16); HRMS (EI) calcd for $\mathrm{C}_{9} \mathrm{H}_{14} \mathrm{O}_{2}{ }^{81} \mathrm{Br}_{2} 315.9320$, found; 315.9325. 


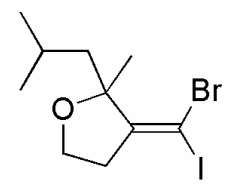

191

3-Bromoiodomethylene-2-isobutyl-2-methyltetrahydrofuran (19l): ${ }^{1} \mathrm{H} \mathrm{NMR}\left(500 \mathrm{MHz}, \mathrm{CDCl}_{3}\right) \delta$ $0.94(6 \mathrm{H}, \mathrm{t}, J=6.6 \mathrm{~Hz}), 1.42(3 \mathrm{H}, \mathrm{s}), 1.59(1 \mathrm{H}, \mathrm{dd}, J=6.5$ and $14.7 \mathrm{~Hz}), 1.74(1 \mathrm{H}$, sept, $J=6.6 \mathrm{~Hz})$, $1.99(1 \mathrm{H}, \mathrm{dd}, J=5.7$ and $14.7 \mathrm{~Hz}), 2.64-2.72(2 \mathrm{H}, \mathrm{m}), 3.83(1 \mathrm{H}, \mathrm{q}, \mathrm{J}=7.9 \mathrm{~Hz}) ;{ }^{13} \mathrm{C} \mathrm{NMR}(125.8 \mathrm{MHz}$, $\left.\mathrm{CDCl}_{3}\right) \delta 23.0,23.9,24.4,24.7,39.7,44.9,45.2,62.4,86.9,157.6$; MS (EI), $\mathrm{m} / z$ (relative intensity) 360, $358\left(\mathrm{M}^{+}, 1,1\right), 345,343(8,8), 303,301(100,100)$; HRMS (EI) calcd for $\mathrm{C}_{10} \mathrm{H}_{16} \mathrm{O}^{81} \mathrm{BrI} 359.9409$, found; 359.9416 .

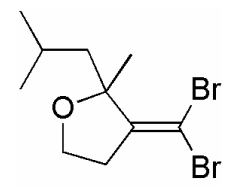

311

3-Dibromomethylene-2-isobutyl-2-methyltetrahydrofuran (311): ${ }^{1} \mathrm{H}$ NMR $\left(500 \mathrm{MHz}, \mathrm{CDCl}_{3}\right) \delta$ $0.94(6 \mathrm{H}, \mathrm{t}, J=6.6 \mathrm{~Hz}), 1.41(3 \mathrm{H}, \mathrm{s}), 1.59(1 \mathrm{H}, \mathrm{dd}, J=6.4$ and $14.6 \mathrm{~Hz}), 1.76(1 \mathrm{H}$, septet, $J=6.6 \mathrm{~Hz})$, $1.95(1 \mathrm{H}, \mathrm{dd}, J=5.7$ and $14.6 \mathrm{~Hz}), 2.65-2.79(2 \mathrm{H}, \mathrm{m}), 3.82(1 \mathrm{H}, \mathrm{dt}, J=7.2$ and $8.4 \mathrm{~Hz}), 3.91(1 \mathrm{H}, \mathrm{dt}, J$ $=4.7$ and $8.4 \mathrm{~Hz}) ;{ }^{13} \mathrm{C}$ NMR $\left(125.8 \mathrm{MHz}, \mathrm{CDCl}_{3}\right) \delta 22.9,23.9,24.4,24.7,40.5,44.8,45.2,78.5,86.8$, 151.9; MS (EI), $m / z$ (relative intensity) 314, 312, $310\left(\mathrm{M}^{+},<1\right), 299,297,295(7,14,7), 257,255,253$ (50, 100, 50); HRMS (EI) calcd for $\mathrm{C}_{10} \mathrm{H}_{16} \mathrm{O}^{81} \mathrm{Br}_{2} 313.9527$, found; 313.9536 .

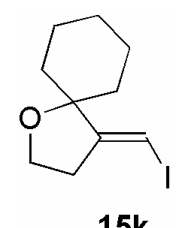

4-Iodomethylene-1-oxaspiro[4.5]decane (15k); Typical Procedure for Proton Transfer-Type Cyclization of Iodoalkynes 13. To a solution of 1-octyne $(0.059 \mathrm{~mL}, 0.40 \mathrm{mmol})$ in THF $(1 \mathrm{~mL})$ under argon atmosphere at $0{ }^{\circ} \mathrm{C}$ was added $\mathrm{BuLi}(1.6 \mathrm{M}$ solution in hexane) $(0.13 \mathrm{~mL}, 0.20 \mathrm{mmol})$. The resulting solution was stirred at $0{ }^{\circ} \mathrm{C}$ for $30 \mathrm{~min}$. To the resulting solution of 1-octynyllithium $(0.20$ $\mathrm{mmol})$ and 1-octyne $(0.20 \mathrm{mmol})$ in THF was added iodoalkyne $13 \mathrm{k}(0.139 \mathrm{~g}, 0.50 \mathrm{mmol})$. The resulting solution was stirred at $0{ }^{\circ} \mathrm{C}$ for $12 \mathrm{~h}$. The mixture was poured into water and extracted twice with ethyl acetate. The combined organic layers were dried $\left(\mathrm{Na}_{2} \mathrm{SO}_{4}\right)$ and concentrated in vacuo. The 
residue was purified by flash chromatography $\left(\mathrm{SiO}_{2}, 3 \%\right.$ ethyl acetate in hexane) to give $0.107 \mathrm{~g}$ ( $77 \%$ yield) of 15k: ${ }^{1} \mathrm{H}$ NMR $\left(500 \mathrm{MHz}, \mathrm{CDCl}_{3}\right) \delta 1.19(1 \mathrm{H}, \mathrm{m}), 1.32(2 \mathrm{H}, \mathrm{m}), 1.53-1.61(4 \mathrm{H}, \mathrm{m}), 1.67(1 \mathrm{H}$, $\mathrm{m}), 1.73(2 \mathrm{H}, \mathrm{m}), 2.61(2 \mathrm{H}, \mathrm{dt}, J=2.6$ and $7.0 \mathrm{~Hz}), 3.91(2 \mathrm{H}, \mathrm{t}, J=7.0 \mathrm{~Hz}), 5.93(1 \mathrm{H}, \mathrm{t}, J=2.6 \mathrm{~Hz}) ;{ }^{13} \mathrm{C}$ NMR $\left(125.8 \mathrm{MHz}, \mathrm{CDCl}_{3}\right) \delta 22.3,25.3,35.6,38.2,63.1,68.8,84.2,160.2$; MS (EI), $\mathrm{m} / z$ (relative intensity) $278\left(\mathrm{M}^{+}, 12\right), 235$ (36), 151 (100); HRMS calcd for $\mathrm{C}_{10} \mathrm{H}_{15} \mathrm{OI} 278.0168$, found; 278.0174 . 